UNIVERSIDADE DE SÃO PAULO

ESCOLA DE ENFERMAGEM DE RIBEIRÃO PRETO

ELLEN CRISTINA BARBOSA DOS SANTOS

\title{
Direitos dos usuários com Diabetes mellitus: \\ do conhecimento à utilização dos benefícios na \\ saúde
}

Ribeirão Preto 


\section{Direitos dos usuários com Diabetes mellitus: do conhecimento à utilização dos benefícios na saúde}

Dissertação apresentada ao Programa de Pós-Graduação em Enfermagem Fundamental da Escola de Enfermagem de Ribeirão Preto da Universidade de São Paulo, para obtenção do título de Mestre em Enfermagem.

Área de concentração: Enfermagem Fundamental.

Linha de pesquisa: Processo de cuidar do adulto com doenças agudas e crônicodegenerativas.

Orientadora: Profa. Dr ${ }^{\mathrm{a}}$. Carla Regina de Souza Teixeira. 


\begin{abstract}
AUTORIZO A REPRODUÇÃO E DIVULGAÇÃO TOTAL OU PARCIAL DESTE TRABALHO, POR MEIO CONVENCIONAL OU ELETRÔNICO, PARA FINS DE ESTUDO, PESQUISA, DESDE QUE CITADA A FONTE.
\end{abstract}

FICHA CATALOGRÁFICA

Santos, Ellen Cristina Barbosa dos

Direitos dos usuários com Diabetes mellitus: do conhecimento à utilização dos benefícios na saúde. Ribeirão Preto, 2009.

143f.:II..; $30 \mathrm{~cm}$

Dissertação (Mestrado - Programa de Pós-Graduação em Enfermagem. Área de Concentração: Enfermagem Fundamental) Escola de Enfermagem de Ribeirão Preto da Universidade de São Paulo.

Orientadora: Profa. Dra ${ }^{\mathrm{a}}$. Carla Regina de Souza Teixeira

1. Enfermagem. 2. Diabetes Mellitus. 3. Direitos do paciente. 4. Políticas Públicas. 5. Bioética. 


\section{FOLHA DE APROVAÇÃO}

\section{Ellen Cristina Barbosa dos Santos}

Direitos dos usuários com diabetes mellitus: do conhecimento à utilização dos benefícios na saúde.

Dissertação apresentada à Escola de Enfermagem de Ribeirão Preto da Universidade de São Paulo, para obtenção do título de Mestre em Enfermagem.

Área de Concentração: Enfermagem Fundamental

Aprovada em l

\section{Banca Examinadora}

$\operatorname{Prof}^{\mathrm{a}} \mathrm{Dr}^{\mathrm{a}}$ Carla Regina de Souza Teixeira (Orientadora)

Professor Doutor do Departamento de Enfermagem Geral e Especializada da Escola de Enfermagem de Ribeirão Preto da Universidade de São Paulo

Assinatura:

$\operatorname{Prof}^{\mathrm{a}} \operatorname{Dr}^{\mathrm{a}}$ Maria Lúcia Zanetti

Professor Associado ao Departamento de Enfermagem Geral e Especializada da Escola de Enfermagem de Ribeirão Preto da Universidade de São Paulo Assinatura:

Prof. Dr. Manoel Antônio dos Santos

Professor Doutor do Departamento de Psicologia e Educação da Faculdade de Filosofia, Ciências e Letras de Ribeirão Preto da Universidade de São Paulo Assinatura: 


\section{Dedicatória}

Aos meus pais, Henrique e Leny Aos meus irmãos, Maico e Tiago Aos meus avós, Tunico e Ilza À minha afilhada Maysa Eduarda

Não tenho palavras capazes de expressar o que vocês representam em minha vida. Vocês, que sempre estiveram ao meu lado, entendendo minhas constantes e necessárias ausências, meu mau humor. Vocês, que compartilharam comigo meus momentos de indecisão, de angústia, de tristezas, de alegrias, de conquistas... Vocês, que sempre me apoiaram, incentivaram e me empurraram para frente quando as forças estavam se exaurindo. Vocês, que acima de tudo representam meu porto seguro... Vocês que são a minha muito amada família!

\section{Ao meu amor, Gabriel,}

Por todos os momentos vividos, por todas as dificuldades enfrentadas, por você se fazer presente em minha vida, mesmo distante, por me amar, por me respeitar, por acreditar sempre na minha capacidade, me apoiando nos momentos difíceis. Enfim, por você ser essa pessoa tão especial, que Deus colocou em minha vida, Simplesmente, Te amo... 


\title{
Agradecimentos
}

\author{
"Nada do que vivemos tem sentido, \\ se não tocamos o coração das pessoas. \\ Muitas vezes basta ser: \\ Colo que acolhe, \\ Braço que envolve, \\ Palavra que conforta, \\ Silêncio que respeita. \\ Alegria que contagia, \\ Lágrima que corre, \\ olhar que acaricia, \\ Desejo que sacia, \\ Amor que promove. \\ E isso não é coisa de outro mundo, \\ é o que dá sentido à vida. \\ É o que faz com que ela \\ não seja curta, nem longa demais \\ Mas que seja intensa \\ Verdadeira, pura ... \\ Enquanto durar" \\ Cora Coralina
}

Apenas humanamente, esse trabalho não seria poderia ser concretizado. Agradeço a Deus, por sua infinita bondade, por dar sentido à minha vida e permitir que milagres acontecessem durante toda a minha trajetória de crescimento pessoal e profissional. Obrigado por suas bênçãos.

Agradeço, à minha querida família, meus pais, meus irmãos, meus avós, minha princesa Maysa e meu noivo Gabriel. Obrigado por cada abraço, cada sorriso e cada palavra de conforto, nos momentos de cansaço e exaustão. Sem vocês nada disso seria possível.

Agradeço, à minha querida orientadora Carla, mulher guerreira e companheira fiel nesta longa caminhada. Obrigada por me compreender, pacientemente, em meus momentos difíceis. Obrigada por acreditar no meu potencial, investir e confiar nisso. Obrigada por ter sido mais que uma orientadora, mas uma amiga. Serei eternamente grata por tudo que fez por mim! Essa conquista é nossa!

Agradeço, à Professora Maria Lúcia Zanetti, pelo carinho, respeito e atenção. Você foi a responsável pela minha iniciação nessa trajetória e uma verdadeira "mãe" ao permitir que eu acreditasse nesse sonho, que hoje se concretiza. Obrigada pelo estímulo e incentivo durante todos esses anos. 
Agradeço, à Professora Carla Ventura e ao Professor Manoel Antônio dos Santos, pelas importantes observações e sugestões, fundamentais para o desenvolvimento desse trabalho.

À equipe multiprofissional da Casa 5, pela constante torcida, apoio e colaboração para a minha formação profissional.

Aos meus eternos amigos de infância, pelas conquistas, pelos desafios, pelo carinho e pelo brilho que vocês dão à minha vida. Sei que posso confiar em vocês. Agradeço em especial, minha grande amiga Lídia pela disponibilidade em me ajudar, nos momentos finais de revisão desse trabalho. Obrigada amiga!

Aos meus amigos, da 48a turma da EERP, por compartilharmos momentos inesquecíveis durante nossa graduação. Agradeço especialmente, minhas amigas Giovana, Karena e Vanessa Gaioso, por permanecerem ao meu lado sempre. Vocês moram no meu coração!

Aos meus amigos residentes do Hospital da Restauração - Recife/PE. Em especial, Juliana, Keyla e Tati. Vocês são pessoas iluminadas, obrigada por todos bons momentos que vivemos juntas.

Aos amigos da pós-graduação, César, Camila, Tânia e Heloísa, obrigado pelos conhecimentos compartilhados e pelas trocas valiosas de experiências.

Aos amigos da Unidade de Emergência do Hospital das Clínicas e do Hospital Estadual de Ribeirão Preto/SP pelo carinho, apoio e torcida. Em especial agradeço minha gerente de enfermagem, Lourdes, pela compreensão das minhas necessidades e pela disponibilidade em me ajudar sempre que precisei.

Por fim, agradeço a todos os pacientes que cruzaram o meu caminho, por me fazer refletir conceitos e assim, me tornar um ser humano melhor. Hoje sei que nada foi por acaso! 


\section{RESUMO}

SANTOS, Ellen Cristina Barbosa. Direitos dos usuários com diabetes mellitus: do conhecimento à utilização dos benefícios na saúde. Ribeirão Preto, 2009. 143f. Dissertação (Mestrado) - Escola de Enfermagem de Ribeirão Preto da Universidade de São Paulo, 2009.

Trata-se de um estudo exploratório-descritivo de abordagem qualitativa, com o objetivo de analisar o conhecimento do usuário com diabetes mellitus acerca dos direitos e benefícios em saúde advindos da legislação vigente. O estudo foi realizado no Centro de Pesquisa e Extensão Universitária do interior paulista com 12 usuários com diabetes mellitus, vinculados ao Grupo de Educação em Diabetes. A coleta de dados ocorreu no período de setembro a dezembro de 2008, através de entrevista semi-estruturada, norteada pela questão relacionada ao conhecimento do usuário com diabetes mellitus e percepção dos benefícios em saúde advindos da legislação vigente. Utilizou-se também, um questionário contendo variáveis sóciodemográficas, variáveis clínicas e variáveis relacionadas ao monitorização da glicemia capilar para caracterização dos participantes da pesquisa. A análise dos temas foi fundamentada nos documentos oficiais identificados através do levantamento acerca dos direitos do usuário em diabetes e dos princípios da Bioética. Os dados obtidos foram agrupados em três temas: a não-consciência dos usuários com diabetes mellitus acerca dos seus direitos; a co-responsabilidade em saúde no que diz respeito ao fornecimento de informações e à efetivação dos direitos dos usuários e, a qualidade da interação profissional-usuário nos serviços de saúde. Apesar dos avanços legalmente alcançados pelas políticas públicas, os usuários com diabetes mellitus em sua maioria desconhecem seus direitos, mas utilizam de maneira não-consciente os benefícios advindos da legislação, tais como, a aquisição gratuita de medicamentos, glicosímetros e tiras para a monitorização da glicemia capilar em domicílio. No entanto, eles percebem o benefício como um favor ou doação. Assim, é de suma importância que haja informação sobre os direitos dos usuários com diabetes, uma vez que, sem a necessária e suficiente informação, torna-se difícil o usuário ser capaz de reivindicar e/ou lutar pelos seus direitos. O desconhecimento dos usuários com diabetes sobre seus direitos resulta na falta de efetivação do exercício de autonomia. As dificuldades apontadas, tais como o acesso a consultas médicas, a impessoalidade da relação entre profissionais de saúde e usuários, apontam para o desejo de humanização no atendimento nos serviços de saúde. Esperamos que os resultados aqui apresentados sobre o conhecimento dos usuários com diabetes mellitus acerca dos seus direitos e benefícios da legislação vigente possam contribuir para a assistência de Enfermagem e dos profissionais da saúde. Para tanto, a necessidade de informação adequada aos usuários dos serviços de saúde nos remete ao papel social que a Enfermagem possui, como um elo entre os usuários e os atuais modelos de saúde vigentes.

Palavras-chave: Enfermagem. Diabetes Mellitus. Direitos do paciente. Políticas Públicas. Bioética. 


\begin{abstract}
SANTOS, Ellen Cristina Barbosa. Rights of users with diabetes mellitus: the use of the knowledge on health benefits. Ribeirão Preto, 2009. 143f. Thesis (Master' Degree) - Ribeirão Preto College of Nursing, University of São Paulo, 2009.
\end{abstract}

This is an exploratory-descriptive study of qualitative approach, aiming to analyze the user's knowledge with diabetes about the rights and benefits in health resulting from legislation. The study was conducted at a Center for Research and Extension University of São Paulo with 12 users with diabetes mellitus, related to the Group for Education in Diabetes. Data collection occurred during September-December 2008, through semi-structured, guided by the question related to the user's knowledge with diabetes mellitus and perception of health benefits derived from the law. It also used a questionnaire containing socio-demographic variables, clinical variables and variables related to the capillary blood glucose monitoring to characterize the participants in the research. The analysis of the themes was based on official documents identified by the survey about user rights in diabetes and the principles of bioethics. The data were grouped into three themes: the non-conscious users with diabetes about their rights, the co-responsibility in health as regards the provision of information and the realization of the rights of users and the quality of interaction professional-user in health services. Despite legal advances made by public policies, users with diabetes mellitus in the majority know their rights, but use of a non-aware of the benefits arising from legislation such as the acquisition of free medications, glucometers and strips for monitoring the capillary blood glucose at home. However, they perceive the benefit as a favor or gift. Thus, it is critical that there is information on the rights of users with diabetes, since without the necessary and sufficient information, it becomes difficult for the user to be able to claim and / or fight for their rights. The unfamiliarity of users with diabetes on their rights results in the lack of effective exercise of autonomy. The difficulties pointed out, such as access to medical consultations, the impersonality of the relationship between health professionals and users point to the desire of humanization of care in health services. We hope that the results presented here on the knowledge of users with diabetes about their rights and benefits of the legislation can contribute to the assistance of nursing and health professionals. Thus, the need for adequate information to users of health services refers to the social role that nursing has, as a link between users and the current existing models of health.

Key words: Nursing. Diabetes Mellitus. Patient Rights. Public Policies. Bioethics. 


\section{RESUMEN}

SANTOS, Ellen Cristina Barbosa. Derechos de los usuarios con diabetes mellitus: el uso de los conocimientos sobre los beneficios de salud. Ribeirao Preto, 2009. 143f. Tesis (Maestría) - Escuela de Enfermería de Ribeirão Preto de la Universidad de Sano Pablo, 2009.

Este es un estudio exploratorio-descriptivo de enfoque cualitativo, con el objetivo de analizar el conocimiento del usuario con diabetes acerca de los derechos y beneficios en la salud derivados de la legislación. El estudio se realizó en el Centro de Investigación y Extensión de la Universidad de São Paulo, con 12 usuarios con diabetes mellitus, en relación con el Grupo de Educación en Diabetes. La recopilación de datos tuvo lugar en septiembre-diciembre de 2008, a través de entrevistas semi-estructuradas, guiadas por la pregunta se refería a que el usuario lo sepa con diabetes mellitus y la percepción de beneficios para la salud derivados de la ley. También se utilizó un cuestionario con variables sociodemográficas, variables clínicas y variables relacionadas con el monitoreo de glucosa en sangre capilar para caracterizar a los participantes en la investigación. El análisis de los temas se basó en los documentos oficiales señalados por la encuesta acerca de los derechos de los usuarios en la diabetes y los principios de la bioética. Los datos se agruparon en tres temas: el no ser consciente de los usuarios con diabetes acerca de sus derechos, la corresponsabilidad en materia de salud en lo que respecta al suministro de información y la realización de los derechos de los usuarios y la calidad de la interacción profesional-usuario en los servicios de salud. A pesar de los avances jurídicos realizados por las políticas públicas, los usuarios con la diabetes mellitus en la mayoría conocen sus derechos, pero el uso de una no-consciente de los beneficios derivados de la legislación, como la adquisición de medicamentos gratis, glucómetros y tiras de control de la de glucosa en sangre capilar en el hogar. Sin embargo, el beneficio que perciben como un favor o regalo. Por lo tanto, es fundamental que exista información sobre los derechos de los usuarios con la diabetes, ya que sin la necesaria y suficiente información, se hace difícil para el usuario para poder reclamar y / o luchar por sus derechos. El desconocimiento de los usuarios con la diabetes en los resultados de sus derechos en la falta de ejercicio efectivo de la autonomía. Las dificultades señaladas, como el acceso a consultas médicas, la impersonalidad de la relación entre los profesionales de la salud y los usuarios apuntan a la voluntad de humanización de la atención en los servicios de salud. Esperamos que los resultados presentados aquí en el conocimiento de los usuarios con diabetes acerca de sus derechos y beneficios de la legislación puede contribuir a la asistencia de enfermería y profesionales de la salud. Así pues, la necesidad de una adecuada información a los usuarios de los servicios de salud se refiere a la función social que tiene la enfermería, como un enlace entre los usuarios y los actuales modelos existentes de la salud.

Palabras-clave: Enfermería. Diabetes Mellitus. Derechos del Paciente. Políticas Públicas. Bioética. 


\section{LISTA DE TABELAS}

Tabela 1 - Distribuição numérica e percentual dos sujeitos atendidos no Centro de Pesquisa e Extensão Universitária segundo o sexo, idade, escolaridade, estado civil, renda familiar, ocupação. Ribeirão PretoSP, 2009.

Tabela 2 - Distribuição numérica e percentual dos usuários com diabetes atendidos no Centro de Pesquisa e Extensão Universitária segundo o tipo de diabetes, tempo de doença, tratamento atual, forma como obtém os medicamentos e instituição de saúde em que realiza acompanhamento. Ribeirão Preto-SP, 2009.

Tabela 3 - Distribuição numérica e percentual dos usuários com diabetes atendidos no Centro de Pesquisa e Extensão Universitária segundo realização de monitorização de glicemia capilar, recebimento de glicosímetro e tiras e participação em programa educativo. Ribeirão Preto-SP, 2009. 


\section{LISTA DE QUADROS}

Quadro 1 - Temas e categorias encontrados nos depoimentos dos participantes. 64 


\section{LISTA DE SIGLAS}

\begin{tabular}{ll} 
ABRASCO & Associação Brasileira de Pós-Graduação em Saúde Coletiva \\
ADA & American Diabetes Association \\
COREN & Conselho Regional de Enfermagem \\
DCCT & Diabetes Control and Complications Trial \\
DM & Diabetes Mellitus \\
EERP & Escola de Enfermagem de Ribeirão Preto \\
EUA & Estados Unidos da América \\
GEDAPS & Grupo de Estudos de La Diabetes en la atención primaria de salud \\
IDF & Internacional Diabetes Federation \\
LOS & Lei Orgânica da Saúde \\
NPH & Neutral Protamine Hagerdorn \\
OMS & Organização Mundial da Saúde \\
OPAS & Organização Pan-Americana de Saúde \\
PET & Programa Especial de Treinamento \\
SBD & Sociedade Brasileira de Diabetes \\
SIH & Sistema de Informação Hospitalar \\
SUS & Sistema Único de Saúde \\
UBS & Unidade Básica de Saúde \\
UBDS & Unidade Básica Distrital de Saúde \\
UKPDS & United Kingdom Prospective Diabetes Study Group \\
USP & Universidade de São Paulo \\
\hline
\end{tabular}




\section{SUMÁRIO}

1.1 O Diabetes mellitus como condição crônica....................................................18

1.2 Políticas de saúde e Legislação Brasileira em Diabetes mellitus ........................25

1.3 Bioética e o exercício dos direitos pelos usuários com Diabetes mellitus 36

2 JUSTIFICATIVA

3 OBJETIVOS 50

4 METODOLOGIA 52

4.1 Tipo de estudo. 53

4.2 Local do estudo 53

4.3 Participantes do estudo...... 54

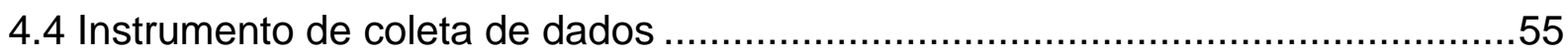

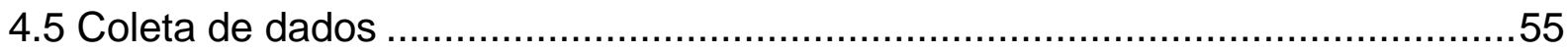

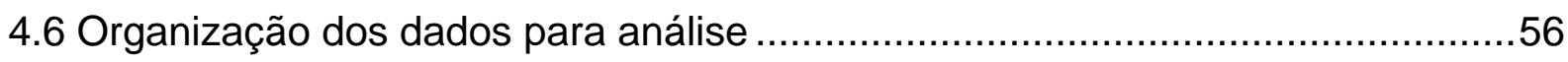

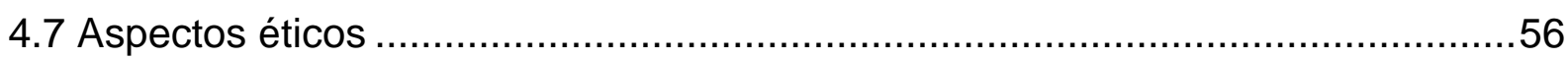

5 RESULTADOS E DISCUSSÃO

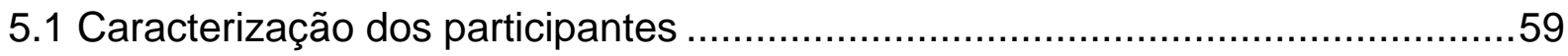

5.2 A não-consciência dos usuários com diabetes mellitus acerca dos seus direitos. 
5.2.1 O (des)conhecimento dos usuários com diabetes mellitus sobre seus direitos

5.2.2 O exercício não-consciente dos direitos pelos usuários com diabetes mellitus

5.3 A co-responsabilidade em saúde no que diz respeito ao fornecimento de informações e à efetivação dos direitos dos usuários com diabetes mellitus.............77

5.3.1 O papel do poder público na divulgação das informações ...............................78

5.3.2 As competências e responsabilidades dos profissionais de saúde: dever ético-moral em informar .85

5.3.3 A participação ou isenção dos usuários na busca por informações 90

5.4 A qualidade da interação profissional-usuário nos serviços de saúde 95

5.4.1 A (des)humanização do atendimento nos serviços de saúde 96 106

APÊNDICES 137

APÊNDICE A - Instrumento de coleta de dados 138

APÊNDICE B - Roteiro de Entrevista Semi-Estruturada 140

APÊNDICE C - Termo de Consentimento Livre e Esclarecido 
APRESENTAÇÃO 
O meu interesse pela temática Diabetes mellitus (DM) teve início logo quando ingressei na Graduação em Enfermagem pela Escola de Enfermagem de Ribeirão Preto da Universidade de São Paulo (EERP/USP), em 2001, quando tive meu primeiro contato com o tema, na qualidade de aluna do Programa BolsaTrabalho/COSEAS até 2002, junto ao Projeto de Pesquisa: Estratégias para o enfrentamento de problemas de pessoas com DM, coordenado pela Prof. Dra. Maria Lúcia Zanetti.

Em 2002, fui aprovada no processo seletivo para bolsistas do Programa Especial de Treinamento (PET), subvencionado pela Secretaria de Educação Superior do Ministério da Educação, e iniciei a pesquisa de Iniciação Científica: "O cuidado a pessoa diabética sob a ótica do paciente e de seus familiares", sob orientação da Prof. Dra. Maria Lúcia Zanetti até final de 2004, ano em que conclui minha graduação.

Durante a graduação, inseri-me na Liga de Diabetes da Escola de Enfermagem de Ribeirão Preto, no ano de 2002, na qualidade de monitora até 2003, no Centro de Saúde Escola "Joel Domingos Machado" - Sumarezinho, da Secretaria Municipal de Saúde de Ribeirão Preto. Em fevereiro de 2003, fui Presidente da Liga de Diabetes da EERP, permanecendo no cargo até julho de 2004. Essas atividades permitiram o desenvolvimento de habilidades educativas, científicas, teóricas e assistenciais relacionadas ao manejo do diabetes, que contribuíram para o meu crescimento profissional.

Foi então que a pesquisa desenvolvida, na qualidade de bolsista do PET, resultou em um artigo científico, que foi publicado na Revista Latino- Americana de Enfermagem, no volume 13, em maio/junho de 2005, sob o título: “O cuidado sob a ótica do paciente diabético e de seu principal cuidador".

Recém-formada e ansiosa com o ínicio da prática assistencial em Enfermagem, ingressei em fevereiro de 2005 no Programa de Residência em Enfermagem em Emergência Geral do Hospital da Restauração da Secretaria de Saúde do Estado de Pernambuco, em Recife, concluindo-o em fevereiro de 2007. Gostaria de destacar que foi nesse ambiente que me interessei pela temática da Bioética em saúde, o que culminou na escolha do tema para o Trabalho de Conclusão de Curso: "Percepção, julgamento e dilemas éticos: profissionais de 
Enfermagem no cuidado de pacientes vítimas/agressores" sob a orientação da Prof. Magaly Bushatsky, da Universidade de Pernambuco.

Em agosto de 2006, iniciei atividades como enfermeira assistencial no Centro de Terapia Intensiva da Unidade de Emergência do Hospital das Clínicas da Faculdade de Medicina de Ribeirão Preto, através do concurso da Fundação de Amparo ao Ensino, Pesquisa e Assistência, retornando novamente a Ribeirão Preto - SP.

Com a volta para Ribeirão Preto-SP e a proximidade do término da Residência em Enfermagem, busquei realizar o antigo desejo de iniciar o Mestrado em Enfermagem pela EERP. Como a paixão antiga, a temática Diabetes mellitus, continuava a me atrair, apenas com uma diferença, agora tinha me encantando também com a Bioética em saúde. Foi quando, após muito estudo, tive a idéia e o total apoio da minha orientadora, de trabalhar com os direitos do usuário com Diabetes mellitus. Assim, surgiu o projeto de pesquisa intitulado como: "Direitos do usuário com diabetes: da legislação à prática". Participei do processo seletivo para Mestrado da Pós Graduação da EERP - USP, sendo aprovada e começando as atividades em fevereiro de 2007, sob orientação da Prof. Dra. Carla Regina de Souza Teixeira.

É importante destacar que, o meu interesse para trabalhar com os direitos do usuário com diabetes surgiu em decorrência da minha experiência profissional e principalmente por observar que, diante dos avanços da Legislação sobre Diabetes Mellitus, fica a curiosidade em conhecer como tem se dado o acesso a esses direitos. Por tal motivo, nos propomos a investigar o conhecimento que o usuário com diabetes possui acerca de seus direitos, de acordo com a legislação vigente. 
1 INTRODUÇÃO 


\subsection{O Diabetes mellitus como condição crônica.}

As condições crônicas constituem problemas de saúde que persistem ao longo do tempo e requerem gerenciamento do sistema de saúde de forma permanente (ORGANIZAÇÃO MUNDIAL DA SAÚDE (OMS), 2003; GUILLET, 2004).

Essas, caracterizam-se pela ausência de microorganismos, pelo longo curso clínico e pela sua irreversibilidade. É um processo de acúmulo e latência de estados de doença ou de disfunções que envolvem o meio ambiente no qual as pessoas estão inseridas e que requerem cuidados, suporte e autocuidado para a preservação das funções vitais e a prevenção de complicações advindas do progresso dessas doenças (LESSA, 1998; LUBKIN; LARSEN, 2002).

Observa-se que em decorrência da queda da taxa de mortalidade infantil e do aumento da expectativa de vida, as condições crônicas tornam-se mais freqüentes na atualidade e, cada vez, mais preocupantes em uma sociedade que se encontra em plena transição demográfica (NISSINEN et al, 2002; OMS, 2003).

Dentre as condições crônicas temos o Diabetes mellitus (DM), doença que apresenta alta morbi-mortalidade, e que influencia diretamente na qualidade de vida das pessoas. (OMS, 2003; GOLDNEY et al., 2004; HOOD et al., 2004).

O aumento da incidência de DM nos países em desenvolvimento é especialmente alarmante. Tal doença, como condição crônica, vem sendo o principal fator de risco para cardiopatias e doenças cerebro-vasculares e comumente tem sido associada à hipertensão arterial, a qual constitui outro importante fator de risco para doenças crônicas (OMS, 2003; OMS, 2005).

O aumento do número de indivíduos com DM está relacionado ao crescimento e ao envelhecimento populacional, à maior urbanização, à crescente prevalência de obesidade e sedentarismo, bem como à maior sobrevida da pessoa com DM, o que configura uma transição demográfica e, consequentemente, uma transição epidemiológica (SOCIEDADE BRASILEIRA DE DIABETES (SBD), 2006; SBD, 2007). 
De acordo com o relatório mundial da OMS (2003), as projeções indicam que em 2025, haverá cerca de 300 milhões de pessoas com DM. Além disso, no mesmo relatório há a informação de que os países em desenvolvimento contribuem com $3 / 4$ da carga global de DM. Isso demonstra que o aumento da doença nos países em desenvolvimento será ainda maior do que nos desenvolvidos.

Em estudo multicêntrico sobre a prevalência do DM realizado em nove capitais brasileiras entre 1986 e 1988, encontrou-se uma taxa de 7,6\% de pessoas com DM como média geral na população urbana de 30 a 69 anos, o que vem a confirmar sua importância dentre a lista de prioridades em saúde. A prevalência varia de 2,7\% para o grupo etário de 30 a 39 anos, até 17,4\% para o grupo de 60 a 69 anos (MALERBI; FRANCO, 1992; SBD, 2007). No fim da década de 90, dados apontam para taxas mais elevadas, como $12,1 \%$ no estudo de Ribeirão Preto, SP (TORQUATO et al, 2003).

Para tanto, temos que o DM corresponde a um grupo de alterações metabólicas caracterizadas por hiperglicemia resultante de defeitos na secreção de insulina, na ação da insulina e/ou em ambas (ENGELGAU; NAYARA; HERMAN, 2000; AMERICAN DIABETES ASSOCIATION (ADA), 2005; SBD, 2007).

A classificação atualmente recomendada incorpora o conceito de estágios clínicos do DM, desde a normalidade, da tolerância à glicose diminuída e/ou glicemia de jejum alterada, até o diabetes propriamente dito. A nova classificação baseia-se na etiologia do diabetes, eliminando os termos "diabetes mellitus insulinodependente" (IDDM) e "não insulino dependente" (NIDDM), a saber: tipo 1, tipo 2, outros tipos específicos e gestacional. O DM tipo 1 resulta primariamente da destruição das células beta pancreáticas, geralmente ocasionando deficiência absoluta de insulina com tendência à cetoacidose. Tal destruição das células beta pancreáticas é mediada por auto-imunidade ou por processos idiopáticos. O tipo 2 resulta de vários níveis de resistência insulínica, sendo mais comum em pessoas obesas. Os outros tipos específicos referem-se aos casos decorrentes de doenças pancreáticas, defeitos associados à outras doenças, ou induzidos por fármacos diabetogênicos. Enquanto o DM gestacional ocorre em decorrência da diminuição da tolerância à glicose, de magnitude variável, diagnosticada pela primeira vez na 
gestação, que pode ou não persistir após o parto (EXPERT COMMITTEE..., 2003; SBD, 2006; SBD, 2007).

O tratamento da pessoa com DM tem como finalidade obter um adequado controle metabólico e deve abranger um programa de educação continuada, modificações no estilo de vida, que incluem aumento da atividade física, reorganização dos hábitos alimentares, abolição do fumo e, se necessário, uso de medicamentos (MILECH, 1998; SBD, 2007; ARÁUZ et al., 2001). A pessoa deve ser continuamente estimulada a adotar hábitos de vida saudáveis como manutenção de peso adequado, prática regular de exercício, suspensão do fumo e baixo consumo de bebidas alcoólicas (WASSERMAN; ZINMAN, 1994; FRANZ et al, 1997; GRUPO DE ESTUDO DE LA DIABETES EN LA ATENCIÓN PRIMARIA DE SALUD, 2000 (GEDAPS); THUOMILEHTO et al., 2001; BRASIL, 2002a; ADA, 2004b).

Existem evidências de que o controle metabólico rigoroso tem papel importante na prevenção do surgimento ou da progressão de suas complicações crônicas, conforme ficou demonstrado pelo Diabetes Control and Complications Trial - DCCT - e pelo United Kingdom Propective Diabetes Study - UKPDS - (DCCT, 1993; UKPDS, 1998; SBD, 2007).

No entanto, a falta de adesão ao tratamento é observada mundialmente. Em países com alto grau de desenvolvimento, cerca de $50 \%$ das pessoas com diabetes não aderem ao tratamento. Acredita-se que, em países com menor nível de desenvolvimento, as taxas são, ainda, maiores (ORGANIZAÇÃO PANAMERICANA DE SAÚDE (OPAS), 2003).

A dificuldade do usuário em usar a medicação prescrita, seguir a dieta ou modificar seu estilo de vida, de acordo com as orientações da equipe multidisciplinar, é um problema sempre presente na prática clínica (FARIA, 2008). Estima-se que apenas $1 / 3$ dos usuários de saúde tem adesão adequada ao tratamento (VALLE et al., 2000).

A adesão a regimes terapêuticos tem sido definida como a extensão na qual o comportamento de uma pessoa coincide com as recomendações do médico ou de outros profissionais de saúde (OMS, 2003). O conceito de adesão a terapia medicamentosa, ainda, é controverso, mas, de forma geral, é compreendido como a 
utilização dos medicamentos prescritos ou outros procedimentos em pelo menos $80 \%$ de seu total, observando horários, doses e tempo de tratamento. Representa a etapa final que se sugere como uso racional de medicamentos (LEITE; VASCONCELLOS, 2003; OSTERBERG; BLASCHKE, 2005).

Assim, o fato de o usuário não aderir adequadamente ao tratamento proposto para o DM pode levá-lo a apresentar complicações de ordem fisiológica e psicossociais, que podem afetar de maneira significativa a sua qualidade de vida. Assim, a questão da adesão à terapêutica medicamentosa tem sido discutida e estudada por profissionais de saúde por se tratar de um ponto fundamental para a resolutividade de um tratamento (LEITE; VASCONCELLOS, 2003).

O descontrole metabólico e, consequentemente, o aumento progressivo da glicemia, decorrentes de uma adesão inadequada ao esquema terapêutico, pode resultar em alterações micro e macrovasculares que culminarão em danos a longo prazo, bem como disfunção e insuficiência de vários órgãos (ADA, 2005).

As complicações decorrentes do DM podem ser classificadas em agudas e crônicas. As complicações agudas incluem a cetoacidose, a síndrome de hiperglicemia hiperosmolar e a hipoglicemia. Dentre as complicações crônicas, temos a nefropatia, com possível evolução para insuficiência renal; a retinopatia, com possibilidade de cegueira; a neuropatia, com risco de úlcera nos pés, amputações, artropatia de Charcot e manifestações de disfunções autonômicas, incluindo a disfunção sexual. Além disso, pessoas com diabetes apresentam risco maior de apresentarem doenças vasculares ateroscleróticas, como doença coronariana, arterial periférica e vascular cerebral (ADA, 2004a; BRASIL, 2002a; OPAS, 2004; FONG et al., 2004; GROSS et al., 2005).

É possível observar que, para que se alcance um bom controle metabólico, o DM requer uma mudança nos hábitos de vida. Essa é uma tarefa difícil e deve levar em consideração alguns fatores que se encontram intimamente entrelaçados com as questões instrumentais e comportamentais que podem influenciar a mudança de hábitos. Tais fatores reportam-se a um conjunto de influências interpessoais familiares e de iguais, e que se encontram alicerçados em crenças e valores que interferem na motivação e na capacidade da pessoa enfrentar a sua doença e buscar soluções para controlar o diabetes. Assim é importante entender os padrões 
individuais de resposta da pessoa com diabetes, bem como de sua família em relação aos seus sentimentos, angústias, ansiedades, conflitos e necessidades (SANTOS et al.,2005).

Ademais, a mudança no estilo de vida é difícil de ser obtida, principalmente quando o diabetes surge após os 40 anos, quando os comportamentos relacionados ao estilo de vida já estão arraigados (ZANETTI, 2002).

Tendo em vista a complexidade da doença e do tratamento e de acordo com o que se pode observar, o DM tem sido um problema de importância crescente em saúde pública. Está associado a complicações que comprometem a produtividade, a qualidade de vida e a sobrevida dos indivíduos (BARBOSA; BARCELÓ; MACHADO, 2001; DAVIS et al., 2005; HOLMSTRÖM; ROSENQVIST, 2005).

Além de comprometer a produtividade, a qualidade de vida e a sobrevida das pessoas, o DM envolve altos custos no seu tratamento e na prevenção e/ou tratamento de suas complicações crônicas e agudas (DAVIS et al., 2005).

Tendo em vista o impacto econômico causado pelo DM, temos os custos considerados como diretos ou indiretos para o sistema de saúde e sociedade. Os custos diretos referem-se às hospitalizações, consultas, complicações e medicações e variam de $2,5 \%$ a $15 \%$ dos gastos em saúde, dependendo da prevalência de diabetes do país e da complexidade do tratamento disponível (BARCELÓ; RAJPATHAK, 2001; OMS, 2002b; INTERNATIONAL DIABETES FEDERATION (IDF), 2002; OPAS, 2004; SBD, 2007).

Os custos indiretos são decorrentes da incapacidade temporária ou permanente do usuário com DM, tais como a perda de produtividade no trabalho, a aposentadoria e a mortalidade precoce (BARCELÓ; RAJPATHAK, 2001; OMS, 2002b; OPAS, 2004; SBD, 2007).

Johnson, Tabaei e Herman (2005) constataram que, em 2002, os custos diretos e indiretos do DM foram estimados em cerca de U\$132 bilhões, apenas nos Estados Unidos. Já o custo atribuído ao tratamento medicamentoso de usuários ambulatoriais foi estimado em $\cup \$ 5,5$ bilhões em 2002, ou 6\% da despesa total do cuidado de saúde (DAVIS et al., 2005). 
Segundo a Secretaria de Políticas Públicas do Ministério da Saúde (BRASIL, 2001a), o número de internações por DM registrado no Sistema de Informação Hospitalar do Sistema Único de Saúde (SIH/SUS) é elevado, tendo sido gastos mais de R\$ 39 milhões com hospitalizações no SUS em 2000. Esses custos estão relacionados à alta taxa de permanência hospitalar do usuário com DM e também à severidade de complicações, que muitas vezes demandam procedimentos de alta complexidade.

Em Ribeirão Preto-SP, as internações por DM, no período de 1988 a 1997, mostraram que a taxa de hospitalização por essa doença foi maior do que as hospitalizações por todas as outras causas, e superior à taxa de crescimento populacional. Mesmo considerando que houve uma redução na duração média de permanência no hospital, a hospitalização por diabetes continua aumentando sua contribuição para o custo direto da assistência ao diabetes (FRANCO; ROCHA, 2002; TORQUATO et al., 2003; SBD, 2007).

Além dos custos diretos e indiretos, o DM acarreta um custo social para a pessoa com DM e seu familiar, afetando a sua qualidade de vida frente à dor e a ansiedade que são geradas com o aparecimento da doença (BARCELÓ; RAJPATHAK, 2001; OMS, 2002b; OPAS, 2004; SBD, 2007).

Para reduzir os custos diretos e indiretos a educação em diabetes tem sido considerada uma ferramenta fundamental no tratamento a pessoa e família. A sua importância vem sendo demonstrada em diversos estudos, realizados em países com diferentes características socioeconômicas e culturais. Assim, as metas da educação em diabetes são obter um bom controle metabólico, prevenir as complicações agudas e crônicas e melhorar a qualidade de vida das pessoas com DM (BROWN, 1990).

Dessa forma, a educação em DM consiste em trabalhar com a pessoa tanto os aspectos instrumentais - falta de conhecimento acerca do manejo de equipamentos específicos - quanto os comportamentais - motivos pessoais ou características e objetivos pessoais individuais (LIMA et al., 2004; SANTOS et al., 2005). 
Diante da magnitude do problema, o DM constitui um grande desafio para o Sistema de Saúde de todos os países. Esse desafio é enorme, pois, na maioria dos países, o Sistema da Saúde está organizado em um modelo de atendimento para pessoas que apresentam condições agudas de saúde.

Nessa direção, vários países e instituições de saúde têm adotado estratégias específicas para enfrentamento do DM. Uma dessas estratégias é denominada Iniciativa de Diabetes para as Américas, da Organização Pan-americana da Saúde (OPAS), e tem como meta principal reduzir a carga social e humana do diabetes na população das Américas. Um dos objetivos é estabelecer trabalho colaborativo com os países membros da OPAS para melhorar a qualidade de vida das pessoas com diabetes (OPAS, 2003; OMS, 2003).

De acordo com a OMS (2003), as condições crônicas representam um sério desafio para os atuais sistemas de saúde no tocante à eficiência e efetividade, pois desafiam as capacidades em organizar sistemas que supram as demandas iminentes. Podem causar sérias conseqüências econômicas e sociais em todas as regiões e ameaçam os recursos da saúde em cada país. Então, somente poderão ser minimizadas quando os líderes do governo e da saúde adotarem mudanças e inovações nas políticas públicas.

Tendo em vista a necessidade de empenho dos líderes do governo na criação de mecanismos que minimizem tanto o aparecimento quanto o agravamento da doença, algumas políticas públicas têm sido instituídas, com o intuito de reduzir os custos advindos da não detecção precoce e das complicações relacionadas ao descontrole metabólico no DM.

Dada à necessidade de proporcionar melhores serviços de atenção e de racionalizar custos, vários países estão revendo suas políticas públicas de saúde. Além disso, os modelos de atendimento vigentes, ainda se encontram voltados para pessoas com problemas agudos de saúde e não para aquelas que apresentam problemas crônicos, tal como o diabetes mellitus. 


\subsection{Políticas de saúde e Legislação Brasileira em Diabetes mellitus}

Em nosso país, a saúde encontra-se estruturada sob a égide do Sistema Único de Saúde (SUS) criado pela Constituição Federal de 1988, que contempla em seu artigo $196^{\circ}$ a saúde como direito fundamental do ser humano e dever do Estado. O SUS tem como seus pilares básicos a universalidade no acesso aos serviços, a integralidade da assistência, a preservação da autonomia das pessoas, a igualdade no atendimento, o direito à informação e a eqüidade na distribuição dos recursos. A sua organização pauta-se pelas diretrizes da descentralização e hierarquização com direção única em cada esfera do governo (federal, estadual e municipal); pelo atendimento integral que compatibiliza as atividades preventivas e assistenciais e pelo controle social, exercido através da participação da comunidade nas conferências e conselhos de saúde (BRASIL, 1990a; ELIAS, 1999).

O SUS foi regulamentado em 1990, pelas Leis $n^{\circ} 8080$ e $n^{\circ} 8142$, as quais conformam a Lei Orgânica da Saúde (LOS) na qual se encontra o detalhamento de diretrizes e da operacionalização de alguns aspectos do sistema (BRASIL, 1990a; BRASIL, 1990b; ELIAS, 1999).

Desde então, os municípios têm buscado definir uma política de saúde comprometida com os princípios da reforma proposta pelo SUS e, com isso, avançar na garantia do direito universal e integral à saúde. No entanto, após 20 anos de implementação, essa ainda não é uma realidade uniforme em nosso país, o qual se depara constantemente com problemas que dificultam a obtenção de resultados positivos, bem como da real efetivação da reforma (BAPTISTA, 2005).

Em uma análise ampliada da política e de todas as estratégias adotadas visando à operacionalização do SUS é possível identificar alguns desafios que se apresentam de forma constante. Esses desafios revelam as heranças deixadas pelos anos de centralização decisória e de prática assistencial focada no Modelo Biomédico e que se mostram reproduzidas nas burocracias institucionais, nas práticas dos serviços, nos modelos assistenciais em saúde, bem como no imaginário social (BAPTISTA, 2005). 
Para a Organização Pan-americana em Saúde (OPAS, 2004), modelo assistencial ou de atenção à saúde é a forma como a sociedade, frente aos determinantes sociais e biológicos da saúde, organiza seus recursos humanos, tecnológicos e materiais para prevenir, integralmente, os riscos à saúde e proporcionar os serviços necessários de fomento, prevenção e atenção em saúde.

Nesse sentido, o SUS foi criado em 1988, como fruto de uma necessidade veemente de prover a reorganização da prática assistencial em substituição ao modelo tradicional biologicista, orientado para a cura de doenças. Frente a essa transição vivida no setor saúde, em 1994, o Ministério da Saúde implanta o Programa de Saúde da Família como estratégia para promover a reforma da prática assistencial a partir da atenção básica à saúde (BRASIL, 2000).

Dessa forma, a importância dos recursos mobilizados no setor saúde, a influência macroeconômica no setor saúde, e a forte tendência ao aumento dos custos da saúde, bem como as dificuldades de financiar este crescimento, têm contribuído para a efetivação do SUS (COUTTOLENC, 2002).

Assim, no Brasil, o Ministério da Saúde e sociedades científicas elaboraram o Plano de Reorganização da Atenção à Hipertensão arterial e ao Diabetes mellitus, em 2002. Esse plano teve como objetivo reduzir: o número de internações, a procura pelo pronto atendimento nas Unidades Básicas de Saúde, os gastos com tratamento de complicações, aposentadorias precoces e a mortalidade cardiovascular, e com isso, promover melhoria da qualidade de vida da população (BRASIL, 2002a).

Nesse contexto, tendo como objetivo principal garantir o acesso da população à assistência farmacêutica, foram criadas resoluções no poder executivo relativas aos direitos dos usuários com diabetes mellitus (BRASIL, 2001b; BRASIL, 2004a; BRASIL, 2006b).

Com o advento das políticas públicas de saúde e com a criação de tais leis, os profissionais de saúde se deparam com a crescente necessidade de incorporar tais políticas em suas práticas cotidianas, necessitando para isso de algumas reflexões e admitindo posturas éticas condizentes com as demandas dos próprios usuários dos sistemas de saúde. 
Para tanto, temos que dentre as questões éticas no exercício profissional estão os direitos do usuário, que se encontram assegurados em vários documentos. Esse tema, que deveria ser um assunto já conhecido e preconizado por todos os profissionais de saúde, precisa ainda ser eficientemente focalizado em nossa realidade (SANTOS; EIDT, 2004).

Pode-se dizer que a reflexão sobre práticas humanizadoras em saúde, se iniciou nos anos 1970 e tem seu marco em 1972, com a publicação da primeira Declaração de Direitos dos Pacientes, emitida pelo Hospital Mont Sinai, em Boston USA. Após um ano, a Associação Americana de Hospitais lançou a Patient's Bill of Rights, a qual foi revisada em 1992 (BANDMAN; BANDMAN, 1978; FORTES, 2004).

Em 1995, o estado de São Paulo, a partir de estudos efetuados pelo Fórum Permanente de Patologias Crônicas, elaborou a Cartilha dos Direitos do Paciente, divulgada pelo Conselho Nacional de Saúde do Estado de São Paulo. Essa cartilha contém as diretrizes que nortearam a proposição da Lei Estadual $n^{\circ} 10.241$, promulgada em março de 1999 (SÃO PAULO, 1999). Essa lei refere-se aos direitos dos usuários dos serviços de saúde e das ações realizadas pelos profissionais de saúde no Estado (SÃO PAULO, 1999; FORTES, 2004).

Tal iniciativa teve repercussões em outros estados brasileiros, sendo promulgada em dois de agosto de 2004 a Lei Municipal n 8926 no município de Belo Horizonte/MG, a qual dispõe sobre os direitos do usuário dos serviços e das ações de saúde no município de Belo Horizonte/MG (BELO HORIZONTE, 2004).

Essas iniciativas tiveram como desdobramento a expansão significativa em relação à humanização dos serviços de saúde e consequentemente aos direitos dos usuários. Com isso, em 22 de fevereiro de 2006 foi divulgada a Portaria $n^{\circ} 399$, denominada Pacto pela Saúde. Essa portaria refere-se ao compromisso firmado entre as três instâncias federativas para a gestão do SUS, e estabelece três prioridades, ou seja, o Pacto pela Vida, o Pacto em Defesa do SUS e o Pacto pela Gestão do SUS (BRASIL, 2007a).

É nesse contexto que surge a inquietude dos gestores do Pacto em Defesa do SUS relativa à elaboração da Carta dos Direitos dos Usuários da Saúde publicada em 30 de março de 2006, e regulamentada pela Portaria $n^{\circ} 675$. Essa 
portaria teve como finalidade disseminar as informações relativas aos direitos dos usuários de saúde junto às instâncias gestoras, aos segmentos profissionais e aos movimentos sociais (BRASIL, 2006a).

A Carta dos Direitos dos Usuários da Saúde foi baseada em princípios básicos de cidadania que em conjunto, asseguram ao usuário/cidadão o direito básico de acesso ao sistema de saúde. Os princípios descritos asseguram ao cidadão o acesso ordenado e organizado ao sistema de saúde; o tratamento adequado e efetivo para o seu problema; o atendimento acolhedor e livre de discriminação que respeite os valores e os direitos do usuário. Além disso, contempla as responsabilidades que o cidadão deve ter para que o seu tratamento aconteça de forma adequada e o comprometimento dos gestores para que todos os princípios anteriores sejam cumpridos (BRASIL, 2006a).

Em relação aos usuários com diabetes, em particular, o governo do Estado de São Paulo, em março de 2001, promulgou a lei no 10.782 que define as diretrizes para uma política de prevenção e atenção integral a saúde da pessoa com de diabetes mellitus, no âmbito do SUS (SÃO PAULO, 2001).

Em consonância com esta lei e com o Plano de Reorganização da Atenção à Hipertensão Arterial e ao Diabetes Mellitus, em 2002 a Secretaria Municipal de Saúde de Ribeirão Preto - SP (SMS - RP), elaborou a Lei Municipal n 10.299 de 2004 (RIBEIRÃO PRETO, 2004). Essa, dispõe sobre as normas de proteção ao usuário com diabetes. Dessa forma, em 2005, publicou-se no Diário Oficial de Ribeirão Preto $n^{\circ} 7348$, as diretrizes orçamentárias para viabilizar o monitoramento e o controle glicêmico da população com diabetes, no município de Ribeirão Preto SP.

Destaca-se que, com base nos direitos advindos da Carta dos Direitos dos Usuários da Saúde, sobretudo o direito ao tratamento adequado e efetivo para o seu problema, e dos acordos entre as três esferas nacionais, em 29 de setembro de 2007, entrou em vigor a Lei Federal no 11.347/06 (BRASIL, 2006b). Essa lei dispõe sobre a distribuição gratuita de medicamentos, materiais para aplicação de insulina e monitorização da glicemia capilar. Tal distribuição está condicionada ao cadastramento e participação dos usuários com diabetes em programas de educação para diabetes. A promulgação dessa lei encontra-se em concordância 
com a Lei $n^{\circ} 8080$, de 1990, que em seu Art. $5^{\circ}$ já previa a assistência terapêutica integral, inclusive farmacêutica, aos usuários de saúde (BRASIL, 1990a).

A fim de regulamentar na prática o cumprimento da Lei Federal $n^{\circ} 11.347 / 06$, foi aprovada pelo Ministério da Saúde, em outubro de 2007, a Portaria n 2.583/07. Essa define o elenco de medicamentos e insumos que devem ser disponibilizados na rede do SUS, destinados ao monitoramento da glicemia capilar dos usuários com DM (BRASIL, 2007b).

De acordo com a Portaria $n^{0} 2.583 / 07$, os medicamentos que devem ser distribuídos gratuitamente aos usuários com diabetes mellitus constituem antidiabéticos orais, como a glibenclamida, o cloridrato de metformina, e a glicazida e insulinas humanas, como a Neutral Protamine Hagerdorn (NPH), que possui ação intermediária e a Regular, que possui ação rápida (BRASIL, 2007b).

No que tange a distribuição de insumos, devem ser disponibilizadas seringas com agulhas acopladas para aplicação de insulina; tiras reagentes para realização de glicemia capilar e lancetas para punção digital (BRASIL, 2007b). Para usufruir De tais direitos, os usuários com DM devem estar cadastrados na Unidade Básica de Saúde mais próxima de sua residência.

As Unidades Básicas de Saúde devem providenciar a inscrição dos usuários com diabetes ao SUS e a carteira de identificação dos mesmos, denominada, cartão SUS (BRASIL, 2006b; BRASIL, 2007b). Além disso, para a aquisição do material previsto na legislação é necessário apresentar o relatório médico com a especificação e forma de tratamento do DM e o receituário médico com todos os itens necessários ao controle da doença. Após esses procedimentos os usuários com diabetes têm acesso na farmácia da Unidade Básica de Saúde aos medicamentos e insumos acima mencionados (RIBEIRÃO PRETO, 2006).

Entretanto, apesar dos avanços alcançados pelas leis acima mencionadas, constata-se que a implementação das mesmas, ainda, carece de ajustes para a operacionalização na prática. Nesse sentido, Garrafa (1993) reforça que é necessário adicionar o progresso moral já verificado na legislação, aos comportamentos públicos. 
Ressalta-se que os comportamentos públicos estão entrelaçados a uma série de dificuldades / deficiências no que se refere à atenção ao diabetes na rede pública de saúde em nosso país. A promulgação da lei não garante a regulamentação dos recursos necessários, tais como os materiais e aparelhos para verificação de glicemia capilar, e os medicamentos e insumos de forma regular e eqüitativa para todos os usuários com diabetes (ASSUNÇÃO; SANTOS; GIGANTE, 2001), bem como não garante também a capacitação da equipe multiprofissional de saúde para o atendimento desse usuário com diabetes (ASSUNÇÃO; SANTOS; GIGANTE, 2001; ASSUNÇÃO, SANTOS, COSTA, 2002).

No que diz respeito aos medicamentos padronizados pelo Programa Nacional de Assistência Farmacêutica para Hipertensão Arterial e Diabetes Mellitus (BRASIL, 2002b) e pela Portaria 2.583 (BRASIL, 2007b), o fornecimento dos análogos da insulina, tal como, a insulina Glargina não está disponibilizado de forma gratuita na rede pública de saúde. No entanto, algumas vezes, esse medicamento, é indispensável para um adequado controle glicêmico do usuário com diabetes, embora seja de alto custo.

Como conseqüência da falta de alguns medicamentos para o controle metabólico do DM para aqueles usuários de difícil controle glicêmico, têm-se verificado a utilização crescente de recursos jurídicos para o acesso aos medicamentos ou insumos necessários aos seus tratamentos (BRASIL, 2005).

Nesse contexto reconhece-se que o Legislativo, o Judiciário e a sociedade civil organizada, além do Poder Executivo, têm assumido papel relevante no processo de implementação de um sistema de saúde de acordo com as diretrizes definidas na Constituição de 1988 (BRASIL, 2005).

O principal instrumento de resposta do Poder Legislativo à pressão da sociedade civil é o Projeto de Lei (BRASIL, 2005). Em um levantamento realizado em outubro de 2004, identificou-se 76 proposituras em tramitação no Congresso Nacional referente à temática saúde, sendo 41 iniciadas na Câmara dos Deputados e 35 no Senado Federal. Das 76 proposituras, 50 (65,8\%) tratavam da garantia dos direitos à saúde referente à aquisição de medicamentos e ao acesso a tratamentos específicos (BRASIL, 2005). 
Por todo o país são inúmeros os casos de medicamentos que passam a ser fornecidos regularmente por força de decisão judicial porque o medicamento não consta da lista oficial do Ministério da Saúde (BRASIL, 2005). Nesse sentido, tem-se a Judicialização da Saúde. Essa pode ser entendida como a atuação do Poder Judiciário com o intuito de intervir nas ações de saúde visando à proteção dos direitos dos usuários legitimados pela constituição de 1988 (BARROSO, 2008).

Nesta situação, temos cidadãos buscando individualmente e através de procedimentos judiciais comuns a efetivação de interesses relacionados ao direito social à saúde, não efetivados na esfera Executiva. No entanto, é preciso que tal processo de Judicialização da Saúde respeite as políticas públicas em vigência, principalmente, no que diz respeito à Política Nacional de Atenção Farmacêutica e as responsabilidades das três esferas governamentais: federal, estadual, municipal (BORGES, 2007).

Nesse sentido, Messeder, Osório-de-Castro e Luiza (2005) realizaram um estudo, com o objetivo de analisar os mandados judiciais para fornecimento de medicamentos aos usuários, impetrados contra a Secretaria Estadual de Saúde do Rio Janeiro, no período de janeiro de 1991 a dezembro de 2002. Os resultados desse estudo apontam para a missão constitucional dos governos, de atender às necessidades de saúde da população. Em contrapartida, a falta de esclarecimento, inclusive da defensoria pública, quanto à divisão das responsabilidades entre as esferas governamentais, parece não assegurar a melhoria de acesso aos medicamentos pelo cidadão além de impedir a concretização da descentralização.

Dessa forma, as ações judiciais, são respaldadas pelo princípio do direito à atenção integral sem limitações e são, portanto, aplicáveis a qualquer tratamento que um usuário necessite e que não tenha provisão pelo Estado. Dados do Ministério da Saúde apontam que no Estado de São Paulo as determinações judiciais para fornecimento de medicamentos e tratamentos específicos passaram de 80 para 600 solicitações mensais, perfazendo um aumento de 650\%. (BRASIL, 2005).

Assim, Varaldo (2003) refere que, o Poder Judiciário pode ser considerado o melhor dos hospitais pelos doentes crônicos de várias doenças e, ainda, reconhece que recorrer à justiça favorece os mais informados. 
Nesse contexto, o SUS depara-se com um paradoxo entre as diferentes demandas de saúde e o conflito ético que diz respeito à alocação dos recursos em saúde. Se por um lado, os usuários requerem por meios judiciais o acesso a medicamentos de alto custo, por outro, a Rede Básica de Saúde, ainda, enfrenta dificuldades para oferecer o atendimento universal e integral preconizado pelo Ministério da Saúde. Acresça-se a isso, que às vezes, também ocorrem problemas relacionados à regularidade no fornecimento de medicamentos já preconizados pelos programas de saúde (BORGES, 2007).

Diante das considerações acima mencionadas, três apontamentos são necessários: o primeiro refere-se à importância do conhecimento das iniciativas do Poder Legislativo como termômetro das pressões sociais, seja na área da saúde ou em qualquer outra. Esses dados mostram, no caso da saúde, a forte preocupação da sociedade com a extensão da cobertura das prestações do SUS, em particular quanto à distribuição dos medicamentos (BRASIL, 2005).

O segundo apontamento, diz respeito à baixa eficácia direta desse tipo de ação legislativa, uma vez que o caminho entre a apresentação da proposta e a sanção presidencial é, sabidamente, longo, tortuoso e, por muitas vezes, lento. Contudo, o Projeto de Lei cumpre um papel importante como fator de mobilização política e social, face a pressão que a sociedade ou parte dela exerce sobre o Executivo (BRASIL, 2005).

A lentidão do poder legislativo, entretanto, não se reproduz no judiciário. A razão é o instituto do Mandado de Segurança com a concessão de Liminar, uma ferramenta rápida de defesa de direitos do cidadão. Com isso, os pedidos de liminares passaram a ser freqüente no campo da saúde e visam, invariavelmente, a garantia do tratamento (BRASIL, 2005).

Desse último aspecto deriva, por fim, um terceiro apontamento quanto aos motivos da necessidade de se recorrer ao Poder Legislativo, aparentemente redundantes, face que a integralidade é um princípio constitucional que dispensaria leis individualizando cada doença, tratamento ou medicamento. Cabe destacar, ainda, que o princípio da integralidade não foi regulamentado por lei (BRASIL, 2005). 
A esse respeito uma das recomendações do estudo realizado pelo Ministério da Saúde (2005), com o objetivo de estudar o financiamento (federal) e o acesso aos serviços de maior custo unitário e/ou densidade tecnológica providos pelo SUS, é que os princípios da universalidade e da integralidade sejam regulamentados por lei, uma vez que como podemos ver:

O fato é que universalidade e integralidade não podem ser entendidas como tudo para todos compatível com um sistema de livre demanda. Não se trata, porém, de instituir restrições, mas criar, democraticamente, regras claras e transparentes. Nem se intenta ferir direitos, mas dar-lhes o necessário sentido social e eqüitativo (BRASIL, 2005, p.15).

É possível notar que, apesar da saúde ter seu arcabouço legal mínimo definido desde a década de 90, suas conseqüências, ainda, não surtiram os efeitos previstos e extremamente necessários para dar conta da estruturação e do funcionamento pleno do SUS. Exemplo disso ocorre com a descentralização, à qual têm se concretizado de forma limitada e limitante, pois tem sido tutelada pela esfera federal, operada por meio de financiamento e demarcada muito mais por seu componente racionalizador do que pelas possibilidades de democratização da instância municipal. Além disso, os problemas relativos ao financiamento persistem e, o controle social, ainda, está em fase de consolidação, abrindo caminhos no seio de uma sociedade desestimulada e desacostumada às ações de cidadania e de um Estado hostil à idéia de ter seus atos fiscalizados pela sociedade (ELIAS, 1999; ZOBOLI, 2003).

Desse modo, pode-se detectar que, a introdução e a adoção de novas maneiras de estruturar o sistema de saúde trazem no seu bojo problemas que exigem uma abordagem ao mesmo tempo crítica e de busca de soluções criativas. Existe uma necessidade crescente de profissionais da saúde que sejam simultaneamente competentes do ponto de vista dos domínios: científico, tecnológico e ético. O século XXI cria a necessidade de um novo paradigma: os profissionais da saúde devem dispor da mesma competência nos três domínios e 
simultaneamente devem ter a habilidade de exercer sua especialidade em diferentes realidades sociais (GOLDIN; FRANCESCONI, 2005).

Com isso, a nossa sociedade deve estar cada vez mais atenta a este desafio e, conseqüentemente, cabe aos profissionais de saúde esforçarem-se para colocar em prática a indissociabilidade das três competências para que resulte, em uma prática clínica na qual os profissionais sejam simetricamente competentes do ponto de vista científico, tecnológico e ético (GOLDIN; FRANCESCONI, 2005).

Assim, é possível encontrar estudos realizados por enfermeiros que tratam as questões éticas, porém mais precisamente a problemática dos direitos dos usuários hospitalizados (CHAVES; COSTA; LUNARDI, 2005; DESLANDES, 2005; VELOSO; ESPINDOLA, 2005). Esses estudos enfocam as questões éticas relacionadas aos direitos em saúde sob diferentes ângulos, tais como: a formação ética dos enfermeiros no Brasil, os modelos éticos relacionados à prática da enfermagem e o conhecimento da equipe de enfermagem acerca dos direitos do usuário hospitalizado.

Tendo em vista a necessidade de se pesquisar acerca dos problemas éticos vivenciados pelos profissionais de saúde e usuários, fora do ambiente hospitalar, em 2003, Zoboli defende sua tese desenvolvida junto ao Programa de Saúde da Família, que teve como objetivo, identificar e comparar, a partir dos relatos dos enfermeiros e médicos, os problemas éticos por eles vivenciados e os fundamentos que balizam o equacionamento da tomada de decisão nesses tipos de situação.

Os problemas éticos apontados pelos dois grupos de profissionais entrevistados confirmam a idéia de que, na atenção básica, estes são constituídos, de maneira geral, por preocupações do cotidiano da atenção à saúde e não por situações críticas e dramáticas que requerem soluções imediatas, como as enfrentadas no contexto da atenção hospitalar e que são mais exploradas na literatura de Bioética. De certa forma, por não serem problemas gritantes, como no âmbito hospitalar ocorre uma dificuldade de percepção pelos profissionais de saúde de quais são os problemas éticos presentes no cotidiano da atenção à saúde (ZOBOLI, 2003). 
Segundo Zoboli (2003) para fazer frente ao desafio de concretização do SUS, parece cabível a urgência de se lidar com os problemas de ordem ética vivenciados nos serviços e sistema de saúde, especialmente na atenção básica. Uma vez que, de acordo com Elias (1999), os serviços de atenção básica correspondem a 78\% dos estabelecimentos de saúde.

Entretanto, constata-se uma lacuna de conhecimento acerca dos direitos do usuário que buscam atendimentos à saúde na rede básica de saúde. Nessa direção, há a necessidade de maior reflexão e discussão acerca dos direitos do cidadão usuário do SUS, pelos profissionais de saúde (SANTOS E EIDT, 2004).

Por fim, o modelo de saúde vigente demanda a aquisição de novas competências pelos profissionais, de novas informações que acompanhem a perspectiva dinâmica do processo saúde-doença, que tenham potencial adaptativo e que respeitem, sobretudo, a ética, o direito e a autonomia dos usuários.

Os direitos do usuário com DM previstos em lei, para que sejam implementados necessitam ser divulgados de modo a torná-los conhecidos da população e dos próprios profissionais de saúde. Tendo a enfermagem como um elo entre os usuários e os atuais modelos de saúde vigentes, fica claro que, cada vez mais, há a necessidade da equipe de enfermagem conhecer e educar os usuários com o intuito de oferecer informações acerca de suas doenças, seus tratamentos e agora dos seus direitos enquanto pertencentes aos sistemas de saúde.

Assim, Gauderer (1998) afirma que, o conhecimento dos direitos dos usuários é essencial para o desenvolvimento de uma consciência democrática, responsável e reflexiva do cidadão, tanto no papel de usuário quanto no de profissional da saúde.

Destaca-se que, conforme Garrafa (1995), pouco se tem trabalhado, em bioética, no campo da saúde pública acerca dos papéis e das responsabilidades éticas de cada um, usuário e profissional de saúde.

Dessa maneira, torna-se evidente a responsabilidade do profissional de saúde, enquanto seres pró-ativos, de incorporarem uma postura reflexiva e ética que contemple a adoção de novos conhecimentos e de novas habilidades necessárias para a efetiva comunicação com os usuários de saúde, configurando uma ambiente 
em que a humanização seja aspecto indispensável. Nisso, reside um dos principais papéis da Bioética.

\subsection{Bioética e o exercício dos direitos pelos usuários com Diabetes mellitus}

Em busca de uma abordagem secular, interdisciplinar, prospectiva, global e sistemática para os temas de ética, em consonância com a afirmação e a construção dos direitos humanos que marcam o mundo moderno nos anos 70 , tem se instaurado na área da saúde, nas últimas três décadas, a Bioética. Antigas concepções verticalizadas, autoritárias, com deveres e princípios absolutos, não são mais aceitas e passam a ser substituídas por alternativas de caráter horizontal e democrático, com responsabilidades recíprocas e bilaterais (GRACIA, 1989; DURANT, 1995, ZOBOLI, 2003).

O neologismo Bioética foi criado por Potter, professor da Universidade de Wiscousin, dos Estados Unidos da América (EUA), em seu livro publicado em 1971. Antes disso, na Universidade de Dakota do Sul, em palestra comemorativa, após 22 anos de pesquisa em oncologia em 1962, ele lançou a idéia do que viria a conformar sua compreensão de Bioética decidindo falar de algo que tinha em mente e que nunca havia sido expresso. Em uma apresentação intitulada "Ponte para o futuro, um conceito de progresso humano" ele questionou o progresso; para onde o avanço materialista da ciência e da tecnologia estaria levando a cultura ocidental; o tipo de futuro que estaríamos construindo e se havia opções. Em 1970, a palestra foi publicada e em janeiro de 1971 o livro, que se tornaram conhecidos do público em geral através de reportagem veiculada pela Revista Time, em 19 de abril de 1971. A partir de então, a palavra emplacou na mídia e a expressão Bioética tornou-se parte da linguagem cotidiana, tendo, seu significado original redefinido, principalmente pelos especialistas em ética médica (POTTER, 1998; PESSINI; BARCHIFONTAINE 2000; ZOBOLI, 2003).

O vocábulo Bioética, literalmente, significa ética da vida. O termo, de raiz grega, bios designa o desenvolvimento observado nas Ciências da vida, como a Ecologia, a Biologia e a Medicina, dentre outras, enquanto ethos busca trazer à 
consideração os valores implicados nos conflitos da vida (GRACIA, 1998a; PESSINI; BARCHIFONTAINE 2000; ZOBOLI, 2003).

Entre os paradigmas comuns, há diferentes tendências que configuram formas de sistematizar e tratar a análise teórica em bioética de modos diferenciados. Dentre tais paradigmas, destacam-se o do liberalismo, que tem nos direitos humanos a justificativa para o valor central da autonomia do indivíduo sobre seu próprio corpo e as decisões relativas à sua vida; o das virtudes que coloca a tônica na boa formação do caráter e da personalidade das pessoas ou dos profissionais; o da casuística que incentiva a análise de casos a fim de elaborar características paradigmáticas para analogias em situações semelhantes; o narrativo que entende a intimidade e a identidade experimentadas pelas pessoas ao contarem ou seguirem histórias como um instrumental facilitador da análise ética; o do cuidar que defende a importância das relações interpessoais e da solicitude e o principialista, baseado nos princípios da beneficência, não maleficência, autonomia e justiça (ANJOS, 1997; PESSINI; BARCHIFONTAINE 2000; ZOBOLI, 2003).

Dentre os paradigmas discutidos anteriormente, o principialismo mostra-se atrativo para a prática da atenção em saúde por propiciar uma linguagem simples, objetiva e que possibilita a verbalização de percepções e sentimentos éticos, permitindo uma abordagem sistematizada dos problemas práticos do atendimento. Possui como protagonistas, Tom Beauchamp e James Childress e sua obra Principles of Biomedical Ethics teve a primeira edição em língua inglesa lançada em fins de 1978 e a quinta em 2002. Os autores propõem quatro princípios como orientadores referenciais para a análise dos problemas éticos: o respeito à autonomia, a não maleficência, a beneficência e a justiça. (BEAUCHAMP; CHILDRESS, 1979).

$\mathrm{Na}$ moral comum, segundo os autores, encontram-se princípios que são básicos para a ética biomédica. Após terem examinado os juízos éticos respeitados e a maneira pela qual as crenças morais ganham consistência, eles defendem quatro agrupamentos de princípios que consideram centrais para a ética biomédica e que podem funcionar como guias de conduta para a ética profissional. Estes incluem o respeito à autonomia (respeito à capacidade de tomar decisão das pessoas autônomas); a não maleficência (evitar causar danos); a beneficência 
(prover benefícios e ponderar benefícios, riscos e custos) e a justiça (a distribuição justa de benefícios, riscos e custos). A escolha dos princípios e a especificação de seu conteúdo decorrem da tentativa dos autores unirem a moral comum e as tradições médicas em um único e coeso pacote (BEAUCHAMP; CHILDRESS, 1979).

De acordo com Oliveira (1997), quatro são as grandes escolas de Bioética: a Escola de Bioética Norte-americana (microbioética - individual/privado), voltada para a defesa dos direitos individuais da pessoa; a Escola de Bioética Européia, centrada na função social das ciências biológicas (macrobioética - coletivo/público); a Escola de Bioética Latino-americana, direcionada para as questões de defesas dos direitos coletivos; e a Escola de Bioética de Inspiração Filosófica Oriental, com uma visão holística da vida, caracterizada pelo humanitarismo, as quais configuram várias correntes de pensamento na Bioética, oriundas de diferentes interpretações filosóficas do mundo e da vida (SANTOS; EIDT, 2004).

Diante das várias abordagens bioéticas, pode-se observar a presença de articulação entre alguns modelos para a busca de respostas ou soluções em situações como as encontradas, por exemplo, em saúde coletiva.

Para Selli (2003) a Bioética não deve se ocupar somente de questões de fronteira, tais como a finitude da vida ou a biogenética, pois assim se limita a uma minoria da população. A seu ver, a Bioética faz parte do cotidiano de todo ser humano e, portanto deve ser enfatizada e voltar-se para os conflitos/dilemas do diaa-dia, como os direitos do usuário e o conteúdo do conceito de cidadania em saúde.

No que tange os direitos do usuário e o exercício de cidadania em atenção básica a saúde, é importante salientar que, de acordo com Brody (1989); Gracia (1998b); Fetters e Brody (1999) e Mayer-Braunack (2001), alguns fatores indicam que os problemas éticos enfrentados na atenção básica devem diferir dos identificados nas demais esferas de atendimento, como por exemplo, o cenário.

Em cada tipo de serviço de saúde há um cenário diferente e isto tem importância na medida em que os problemas de ordem ética emergem do contexto no qual se inserem. Nas unidades básicas de saúde, os encontros entre os profissionais de saúde e os usuários são mais freqüentes e em situações de menor urgência. Assim, "a emergência, a imediatidade e a dramaticidade das situações 
vivenciadas", por exemplo, em situações de emergências, fazem com que os problemas éticos sejam freqüentemente mais evidentes, enquanto nas unidades básicas de saúde apresentam-se tipicamente de maneira mais sutil, passando, muitas vezes, desapercebidos (ZOBOLI; FORTES, 2004, p.1691).

Além disso, as soluções encontradas para situações éticas similares podem diferir nos diversos serviços de atenção à saúde, pois ainda que se observe a mesma estrutura de raciocínio ético, os sujeitos éticos e o contexto são distintos (ZOBOLI, 2003).

Assim, a partir destas considerações pode-se observar com Gracia (1998b) que:

...Fica evidente que a atenção primária não só lida com eixos distintos que a terciária, como também pertence a um mundo de valores de maior amplitude e complexidade (...) dito de outra maneira, a atenção primária exige um manejo de Bioética Clínica que não é diferente, mas mais complexo do que na atenção terciária. Isso, oferece uma boa idéia sobre a importância da formação em Bioética pelos programas de atenção familiar e comunitária (p. 100).

Algumas mudanças sociais ocorreram nos últimos tempos e essas, guardam uma relação direta com as mudanças observadas nos usuários e também nos profissionais de saúde. Destacam-se as organizações de grupos em minorias, nas quais grupos de determinadas doenças, como o diabetes e outras, tornam-se cada vez mais organizados e articulados na busca de soluções para os problemas ligados aos seus grupos. Isso desencadeia mudanças na organização e no próprio financiamento do sistema de saúde, o qual passa a lidar com pressões legais, em decorrência da ascensão da medicina defensiva e dos direitos dos usuários (CASSEL, 1993).

Assim, a partir dos anos 80, a Bioética começou a ampliar seu foco vislumbrando a relação clínica com o contexto de sistema de saúde e, consequentemente, incorporando reflexões acerca das questões relativas à 
estrutura, à gestão e ao financiamento deste sistema (PESSINI; BARCHIFONTAINE 2000; ZOBOLI, 2003).

Neste período, a difusão da Bioética em direção aos países do hemisfério sul, especialmente a América Latina, onde convivem "ilhas de excelência tecnológica em saúde com a extrema pobreza da maioria das populações", torna-se fundamental a inclusão dos problemas da coletividade na agenda das discussões, com temas como o acesso aos serviços de saúde, a alocação de recursos em saúde, as questões demográficas e populacionais, a responsabilidade social e coletiva sobre as condições de saúde, bem como os direitos desses usuários à saúde (FORTES; ZOBOLI, 2003).

Para tanto, o Programa Regional de Bioética para a América Latina e Caribe, desde seu estabelecimento pela Organização Pan-americana da Saúde, em 1994, define dentre as prioridades temáticas em Bioética para a região, a ética em Saúde Pública (OPAS; OMS, 1995).

No fim da década de 90, de acordo com Wikler (1997) inicia-se a chamada Bioética da saúde das populações. Nesse momento, entra em cena com mais vigor os Direitos Humanos e as Ciências Sociais e Humanas, conferindo, desta maneira, um maior destaque às questões da eqüidade e da alocação de recursos em saúde (PESSINI; BARCHIFONTAINE, 2000).

Logo, passa-se a discutir o acesso aos serviços de saúde, a tecnologia neles incorporada e a forma como os direitos dos usuários são concretizados na prática. Além disso, há a preocupação com as questões demográficas; a priorização dos países em desenvolvimento; a necessidade de um novo marco conceitual que, apropriando-se de conceitos e teorias de outros campos do conhecimento humano, dê conta das demandas de reflexão geradas por esta Bioética da saúde das populações (ZOBOLI, 2003).

Portanto, sem desconhecer a relevância dos temas tratados mais enfaticamente pela Bioética até o momento, é urgente ampliar e redirecionar as atuais orientações. Esta tarefa torna-se mais prioritária ainda para os que estudam e refletem a Bioética no Brasil. Isto porque, como alerta Clotet (1995), da forma que vem sendo tratada, a Bioética tem se ocupado de problemas que afetam apenas um 
número reduzido de pessoas nos países, o que pode lhe impor o risco de isolar-se do fluxo de exigências e experiências comuns a todos e/ou que dizem respeito aos grupos menos privilegiados de países pobres.

Tendo em vista essa necessidade de redirecionamento, uma linguagem que vem sendo utilizada em Bioética é a de que o exercício dos direitos, pelos usuários, deve visar o alcance da humanização dos serviços de saúde, além de garantir a cidadania em saúde. Nesse contexto, o direito à saúde passa a constituir o "valor-mor" do paradigma bioético (GARRAFA et al, 1997; PESSINI; BARCHIFONTAINE 2000).

Para Fortes (1994), o direito é o elemento principal da ordem da cidadania. Dessa maneira, o respeito aos direitos dos cidadãos funciona como um dos principais indicadores de qualidade no planejamento e na gestão dos serviços de saúde. Para tanto, temos com Zoboli (2003) que a justiça distributiva, refere-se à distribuição dos direitos e responsabilidades na sociedade, incluindo os direitos civis e políticos.

Atualmente, as pessoas com DM, dispõem no mercado de uma ampla variedade de medicamentos, insumos e aparelhos para o controle da sua doença. Constata-se que, a criação de normas e rotinas creditadas e validadas por leis e portarias, podem vir a configurar uma legislação ativa, eficaz, com um pensamento ético vigente, contemplando a participação social e o pleno exercício da cidadania.

No entanto, apesar dos avanços conquistados por meio das leis, verifica-se que os usuários de saúde, ainda hoje, têm pouco acesso a esses benefícios tecnológicos, exercendo minimamente seus direitos como cidadãos (BOSI; AFFONSO, 1998; SAWYER; LEITE; ALEXANDRINO, 2002; BERLINGUER, 2004).

Para tanto temos com Baptista (2005) que, o processo de construção de nossa cidadania esbarrou em obstáculos de toda ordem no decorrer da história, tais como a segmentação dos direitos por classes sociais, etnia e sexo; a valorização do trabalhador, através da cidadania regulada. Assim como, o estímulo ao corporativismo extremado no conflito de interesses de cada categoria, além dos períodos de ditadura em momentos-chave de transformação política e social.

Uma das prioridades do Pacto pela Saúde é reforçar o SUS como uma política de Estado que tem seus princípios garantidos na Constituição Federal. Configura-se em um compromisso entre os gestores do SUS para a efetivação de 
iniciativas que ampliem a mobilização social e promovam a cidadania, favorecendo o acesso e maior qualidade aos serviços de saúde (BRASIL, 2007a).

Assim sendo, verifica-se a necessidade de um apoio efetivo, fornecido por uma equipe de saúde capacitada para a educação permanente da pessoa com DM. Essa equipe deve informar, instruir, orientar, acompanhar e se mostrar solícita, a fim de que exista a criação de um vínculo efetivo, com o objetivo principal de promover a melhoria da qualidade da assistência às pessoas com DM (TEIXEIRA; ZANETTI, 2006).

Portanto, não se trata apenas de construção de normas, portarias, ou leis, mas da praticidade de implementação das mesmas, visando a melhora do controle metabólico dos usuários com DM, priorizando a individualidade inata de cada ser humano e propiciando a formação de cidadãos capazes de exercer seus direitos e autonomia, perante um quadro de justiça distributiva.

Tal praticidade pode encontrar seu respaldo de duas formas, a primeira é a garantia ao usuário com DM às informações sobre seus direitos legais de cidadãos, que deverão ser fornecidas por uma equipe de saúde capacitada. A segunda, diz respeito à provisão de recursos, bem como a alocação adequada dos mesmos, para que o acesso seja atingido de forma justa e eqüitativa.

Tendo em vista ainda a configuração atual da saúde brasileira, nota-se a incongruência entre a oferta de medicamentos, insumos, aparelhos e a utilização adequada desses pelos usuários. De acordo com o Ministério da Saúde, os fatores mais comuns para as demandas judiciais, no caso de medicamentos são: falta do remédio, droga não padronizada pelos programas e outros fatores, como por exemplo, medicamentos não disponíveis no mercado nacional (BRASIL, 2005).

No que diz respeito à utilização adequada dos materiais e às condutas a serem tomadas frente aos resultados obtidos dos exames de glicemia capilar realizadas no domicílio observa-se falta de acolhimento nos serviços de saúde, relacionada às informações necessárias para o manejo da doença, o que configura uma falha direta na comunicação efetiva entre profissionais de saúde e usuários, bem como a ausência de formação de um elo eficaz entre os mesmos (ADA, 2004b; SBD, 2006). 
Em uma pesquisa realizada em serviços de atenção básica no Kentuchy (EUA) com diversos profissionais de saúde (médicos, enfermeiros, fisioterapeutas etc.), Robillard et al. (1989), obtiveram resultados que confirmam o fato das ocorrências éticas mais comuns na atenção básica configurarem as preocupações pragmáticas do dia-a-dia, especialmente as ligadas à prática clínica. Nessa pesquisa, os doze primeiros problemas apontados como os mais freqüentes não são dramáticos ou tampouco merecedores de destaque na mídia, mas ocorrem repetidamente. Dentre eles, temos: a falta de preparo e atualização dos profissionais de saúde; o tratamento desrespeitoso para com os usuários; a informação inadequada fornecida aos usuários; dentre outros.

A necessidade de informação adequada aos usuários dos serviços de saúde nos remete ao papel social que a Enfermagem possui. No que diz respeito à informação, temos com Selli (2003), que essa faz parte do cuidado ao usuário, sendo uma atitude justa orientá-lo devidamente para que ele possa buscar os recursos que a sociedade coloca à sua disposição para o tratamento.

Discussões atuais, advindas da criação dos direitos dos usuários, referenciam a Bioética como moderadora das ações de saúde e das repercussões dessas ações, conduzindo a reflexões acerca direitos dos usuários, acesso a esses direitos e disseminação de informações relativas ao uso adequado desses direitos pelos serviços de saúde.

Diante disso, Pessini e Barchifontaine (2000) inferem que a Bioética propõe questões acerca da humanização e da personalização dos serviços de saúde, bem como a promoção dos direitos do paciente, promovendo a articulação entre Ética e Ciências biomédicas. A interdisciplinaridade e a interculturalidade aliada à valorização do diálogo constituem um dos métodos privilegiados da humanização e da conseqüente, personalização dos serviços de saúde.

Assim, torna-se claro a importância da Bioética permear todos os passos da Enfermagem, norteando suas práticas, diante de qualquer usuário, e em particular aquele com DM, que já conquistou seu espaço diante da formulação de leis e se encontra no estágio de operacionalização com praticidade das mesmas (SELLI, 2003). 
Uma das abordagens bioéticas que mais se utiliza na saúde, atualmente, se refere ao Modelo Principialista. Esse encontra-se baseado em quatro princípios fundamentais, os quais são definidos como autonomia, beneficência, nãomaleficência e justiça. Por autonomia entende-se a capacidade que a pessoa possui em autogovernar-se, de possuir liberdade de escolha e de agir em conformidade com sua própria vontade. A beneficência está intrinsecamente relacionada ao comportamento ético de fazer o bem, visando à promoção do bem estar das pessoas. A não-maleficência diz respeito à necessidade de prevenir e retirar possíveis danos às pessoas, resumindo-se a não fazer o mal. O princípio da justiça exige eqüidade na distribuição de bens, benefícios e serviços prestados na saúde (BEAUCHAMP, CHILDRESS, 1979).

Dentre os princípios acima discutidos, o princípio da justiça é essencial quando se trata dos direitos dos usuários com DM. Tal princípio, segundo Pessini e Barchifontaine (2000), pode garantir uma distribuição justa, eqüitativa e universal dos benefícios dos serviços de saúde, perspassando ainda por questões como o exercício da cidadania e do direito à saúde.

Ainda no que tange a distribuição eqüitativa dos benefícios nos serviços de saúde, é importante ressaltar que a incorporação de novas tecnologias em saúde, deve levar em consideração quais serão as repercussões sociais do novo método, assegurando sempre que o bem proveniente da nova técnica ou tecnologia seja distribuído de maneira igualitária a toda população e não a apenas uma parcela de abastados, que podem pagar (GOLDIN; FRANCESCONI, 2005).

Nisso consiste a consciência ética das inovações técnicas e tecnológicas. Não se pode, ou não se deve oferecer tratamentos ou insumos diferentes para usuários com condições sociais e econômicas diferentes. A priori, a oferta pelo sistema de saúde deve ser eqüitativa e igualitária, em obediência ao princípio Bioético da Justiça.

Outro aspecto que também deve ser considerado é o da alocação de recursos escassos dentro da nossa situação socioeconômica. Quando se contempla a saúde de uma região, o administrador dos recursos econômicos deve considerar tanto aspectos técnicos relacionados à aquisição de novos equipamentos, quanto os 
aspectos éticos relacionados à priorização dos diferentes custos dentro de um macroperspectiva de política de saúde (GOLDIN; FRANCESCONI, 2005).

Assim, de acordo com Garrafa, Oselka e Diniz (1997) a equidade é um princípio instrumentalizador do direito à saúde, uma vez que promove o reconhecimento de necessidades diferentes, de sujeitos também diferentes, para atingir direitos iguais.

Tendo em vista a alocação de recursos, a legislação que define o elenco de medicamentos e insumos disponibilizados pelo Sistema Único de Saúde aos usuários com diabetes mellitus segue o princípio da equidade. Tal fato pode ser evidenciado, através das recomendações para a monitorização da glicemia capilar. Os usuários com DM tipo 2, que utilizam para o tratamento antidiabéticos orais, devem realizar a monitorização da glicemia na própria unidade de saúde. Os usuários com diabetes tipo 1 , têm o direito de receber, gratuitamente do serviço de saúde, o glicosímetro e as tiras reagentes necessárias para a realização da glicemia capilar em domicílio (BRASIL, 2007b). Dessa forma, tem-se a distribuição dos benefícios em saúde, de acordo com as necessidades de cada usuário, o que configura o respeito à equidade e à justiça distributiva.

Nesse sentido, problematizar questões relacionadas à escassez de recursos e alocação dos mesmos poderá dar origem a estratégias que beneficiem a desconstrução de práticas vigentes, contribuindo para que haja o exercício da cidadania do usuário com DM, no âmbito de uma justiça distributiva. Assim esperase que, os direitos dos usuários com diabetes sejam respeitados e possam ser compreendidos e agregados às práticas diárias dos profissionais de saúde e dos próprios usuários do SUS. Dessa forma, torna-se evidente a responsabilidade do profissional de saúde de incorporar uma postura reflexiva e ética que contemple a adoção de novos conhecimentos e de novas habilidades necessárias para a efetiva comunicação com os usuários dos serviços de saúde.

Assim sendo, nos propomos à seguinte questão de investigação: O que os usuários com DM conhecem acerca dos seus direitos e como os tem utilizado diante da legislação vigente sobre diabetes? 
2 JUSTIFICATIVA 
Segundo, Wild et al (2004), uma epidemia de DM está em curso. Em 1985 estimava-se que existissem 30 milhões de adultos com DM no mundo; esse número cresceu para 135 milhões em 1995, atingindo 173 milhões em 2002, com projeção de chegar a 300 milhões no ano 2030. Cerca de dois terços desses indivíduos com DM vivem nos países em desenvolvimento, onde a epidemia tem maior intensidade, com crescente proporção de pessoas afetadas em grupos etários mais jovens (SBD, 2007).

No Brasil, no final dos anos 1980, a prevalência de DM na população adulta foi estimada em 7,6\% (MALERBI; FRANCO, 1992); no fim da década de 90, dados apontam para taxas mais elevadas, como $12,1 \%$ no estudo de Ribeirão Preto, SP (TORQUATO et al, 2003).

A natureza crônica, a gravidade de suas complicações e os meios necessários para controlá-las torna o DM uma doença muito onerosa, não apenas para os indivíduos afetados e suas famílias, mas também para o sistema de saúde. Os custos dos cuidados de saúde para um indivíduo com DM nos EUA foi estimado em duas a três vezes maiores do que o de um sem a doença (SBD, 2006).

No entanto, a falta de adesão nos tratamentos é observada no âmbito mundial. Em países com alto grau de desenvolvimento, cerca de 50\% das pessoas com DM não aderem ao tratamento. Em países com menor nível de desenvolvimento, acredita-se que, as taxas são ainda maiores (OPAS, 2003).

Dessa forma, há necessidade de estabelecer políticas públicas voltadas para a criação de mecanismos que minimizem tanto 0 aparecimento quanto 0 agravamento da doença, com o intuito de reduzir os custos advindos da falta de detecção precoce e das complicações relacionadas às dificuldades de controle metabólico no DM (OMS, 2003).

Nesse sentido, em 29 de setembro de 2007, entrou em vigor a Lei Federal $\mathrm{n}^{\circ}$ 11.347/06, que dispõe sobre a distribuição gratuita de medicamentos e materiais necessários à sua aplicação e à monitorização da glicemia capilar aos usuários com DM inscritos em programas de educação para diabetes, em consonância com a Lei $n^{\circ} 8080$, de 1990, que em seu Art. $5^{\circ}$ já previa a assistência terapêutica integral, inclusive farmacêutica (BRASIL, 1990a; BRASIL, 2006b). Com o objetivo de detalhar 
e regulamentar a distribuição gratuita dos benefícios advindos da Lei Federal $\mathrm{n}^{\circ}$ 11.347/06, a Portaria no 2.583/07, define o elenco de medicamentos e insumos que devem ser disponibilizados aos usuários com DM, no âmbito do SUS.

Por outro lado, para que sejam implementados os direitos do usuário com DM previstos na legislação, é necessário que esses sejam divulgados de modo a tornálos conhecidos da população e dos próprios profissionais de saúde. Sendo a Enfermagem um elo de ligação entre os usuários e os atuais modelos de saúde vigentes, fica claro que, cada vez mais, há a necessidade da equipe de enfermagem conhecer e educar os usuários com o intuito de oferecer informações acerca de sua doença, seu tratamento e os seus direitos enquanto pertencentes aos sistemas de saúde.

Dessa maneira, torna-se evidente a responsabilidade de todo profissional de saúde, como seres pró-ativos, de incorporarem uma postura reflexiva e ética que contemple a adoção de novos conhecimentos e de novas habilidades necessárias para a efetiva comunicação com os usuários de saúde, configurando um ambiente em que a humanização seja aspecto indispensável. Nisso reside um dos principais papéis da Bioética (PESSINI; BARCHIFONTAINE, 2000).

Tendo em vista a necessidade de redirecionamento da prática assistencial, uma linguagem preconizada pela Bioética é a de que o exercício dos direitos, pelos usuários, deve visar o alcance da humanização dos serviços de saúde, além de garantir a cidadania em saúde. Nesse contexto, o direito à saúde passa a constituir o "valor-mor" do paradigma Bioético (GARRAFA et al, 1997; PESSINI; BARCHIFONTAINE 2000).

Para tanto, e com o intuito de promover a humanização dos serviços de saúde, há duas formas de garantir os direitos dos usuários com DM. A primeira é a garantia às informações sobre seus direitos legais de cidadãos, que deverão ser fornecidas por uma equipe de saúde capacitada. A segunda diz respeito à provisão de recursos, bem como a alocação adequada dos mesmos, para que o acesso seja alcançado de forma justa e eqüitativa.

Sabendo que, o conhecimento dos direitos dos usuários é essencial para o desenvolvimento de uma consciência democrática, responsável e reflexiva do 
cidadão, tanto no papel de usuário quanto no de profissional da saúde, conhecer os direitos é o primeiro passo para diminuir as barreiras enfrentadas pelos usuários com diabetes mellitus para 0 acesso pleno a seus direitos de cidadania (GAUDERER, 1998). Nesse sentido, o presente estudo tem por objetivo investigar o conhecimento dos usuários com diabetes mellitus acerca dos seus direitos e como eles têm se apropriado dos benefícios em saúde advindos da legislação vigente. 
3 OBJETIVOS 
Analisar o conhecimento do usuário com diabetes mellitus acerca dos direitos e benefícios em saúde advindos da legislação vigente. 
4 METODOLOGIA 


\title{
4.1 Tipo de estudo
}

Trata-se de um estudo de caráter exploratório-descritivo. Segundo Triviños (1995) os estudos exploratórios permitem ao investigador aumentar sua experiência em torno de um determinado problema, e os estudos descritivos pretendem descrever (e também analisar) os fatos e fenômenos de uma determinada realidade.

Para este estudo foi utilizada uma abordagem qualitativa a qual segundo Minayo (2001, p.21):

\begin{abstract}
...responde a questões muito particulares. Ela se preocupa, nas Ciências Sociais, com um nível de realidade que não pode ser quantificado. Ou seja, ela trabalha com o universo de significados, motivos, aspirações, crenças, valores e atitudes, o que corresponde a um espaço mais profundo das relações, dos processos e dos fenômenos que não podem ser reduzidos à operacionalização de variáveis.
\end{abstract}

Segundo Pope e Mays (2005), a pesquisa qualitativa está relacionada aos significados que as pessoas atribuem às suas experiências do mundo social e como as pessoas compreendem esse mundo. Tentando, portanto, interpretar os fenômenos sociais como interações, comportamentos, etc., em termos dos sentidos que as pessoas thes dão; sendo em função disso comumente referida como pesquisa interpretativa. Dessa forma, a escolha do método qualitativo possibilita apreender como os usuários com diabetes percebem os seus direitos e utilizam os benefícios advindos da legislação em diabetes.

\subsection{Local do estudo}

O estudo foi realizado no Centro de Pesquisa e Extensão Universitária do interior paulista. Neste Centro funciona o Grupo de Educação em Diabetes, onde 
são desenvolvidas atividades de ensino, extensão e pesquisa vinculados ao Departamento de Enfermagem Geral e Especializada da Escola de Enfermagem de Ribeirão Preto, da Universidade de São Paulo.

A equipe interdisciplinar é composta voluntariamente por duas docentes da Escola de Enfermagem de Ribeirão Preto - USP, uma enfermeira de apoio da Escola de Enfermagem de Ribeirão Preto, dois nutricionistas clínicos, um psicólogo docente da Faculdade de Filosofia, Ciências e Letras de Ribeirão Preto - USP, dois psicólogos clínicos, quatro educadores físicos e alunas do curso de psicologia e enfermagem. A coordenação geral do Serviço é realizada por uma docente da Escola de Enfermagem de Ribeirão Preto da Universidade de São Paulo.

O grupo atende às terças-feiras, no horário das 14:00h às 17:00h e o programa educativo tem duração de quatro meses. Sua proposta prevê que cada equipe de Psicologia, Nutrição, Educação física e Enfermagem tenham um encontro de duas horas com cada grupo, a cada semana, alternando-se para outra equipe na semana subseqüente. Para o desenvolvimento do programa educativo a equipe opta por um tema por mês, o qual constitui o eixo de trabalho para todas as equipes. Os temas são abordados na seguinte ordem: conhecendo o diabetes mellitus, alcançando a alimentação saudável, praticando o exercício físico, a terapia medicamentosa em diabetes, e prevenindo as complicações agudas e crônicas. Após a participação na atividade grupal, os usuários com diabetes realizam a mensuração de glicemia capilar, pressão arterial, peso corporal e circunferência abdominal que são registrados em seus prontuários.

O convite para a participação no programa educativo é divulgado na mídia, onde os usuários procuram o serviço por livre demanda. No período de agosto a dezembro de 2008, foram cadastrados no Centro, 41 usuários com diabetes.

\subsection{Participantes do estudo}

Participaram do estudo, 12 usuários com diabetes do tipo 1 e 2, de ambos os sexos, vinculados ao Grupo de Educação em Diabetes de agosto a dezembro de 2008. 


\subsection{Instrumento de coleta de dados}

Para a coleta de dados objetivos foi utilizado um questionário contendo variáveis sócio-demográficas (sexo, idade, escolaridade, estado civil, renda familiar e ocupação), variáveis clínicas (tipo de DM, tempo de doença, tratamento atual, modo de aquisição do medicamento e instituição de saúde em que realiza o acompanhamento da doença), e variáveis relacionadas à monitorização da glicemia capilar (realização da monitorização da glicemia capilar, recebimento de glicosímetro e tiras reagentes para glicosimetria e partipação em programa educativo (APÊNDICE A).

Para os dados subjetivos, optou-se pela entrevista semi-estruturada, devido seu caráter flexível, na medida em que não apresenta uma padronização de pergunta e resposta, oferecendo a possibilidade do sujeito alcançar uma maior liberdade e espontaneidade para falar. De acordo com Triviños (1995), a entrevista semi-estruturada é aquela que oferece amplo campo de interrogativas à medida que o entrevistado fornece suas respostas e, deste modo, obtém resultados mais aproximados da verdade. Para tanto, o estudo teve a seguinte questão disparadora (APÊNDICE B): quais as informações que o (a) senhor (a) possui acerca de seus direitos como usuário com diabetes nos serviços de saúde e como o (a) senhor (a) têm utilizado os seus direitos?

\subsection{Coleta de dados}

A coleta de dados ocorreu no período de setembro a dezembro de 2008. Os dados foram coletados pelo pesquisador após a participação do usuário na atividade do grupo.

Para a coleta de dados procedeu-se a explicação da natureza da pesquisa e os objetivos do trabalho. Com a anuência dos sujeitos e a permissão para gravação em áudio da entrevistas, era solicitado a assinatura do Termo de Consentimento 
Livre e Esclarecido. As entrevistas foram aplicadas individualmente em situação face a face, em ambiente preservado e com condições adequadas de conforto, com duração média de 30 minutos.

Por ser esta uma pesquisa de cunho qualitativo, 0 critério de representatividade da amostra para o encerramento da coleta de dados não foi o numérico, mas a variabilidade que permitiu abranger a totalidade do problema investigado em suas múltiplas dimensões, ou seja, o da saturação do discurso. Segundo Pope e Mays (2005) tal amostra se dá como esgotada ou satisfatória quando se obtém respostas com profundidade para os questionamentos estabelecidos, em associação à repetição do discurso por outros entrevistados.

\subsection{Organização dos dados para análise}

Os dados objetivos referentes às variáveis sócio-demográficas, clínicas e relacionadas à monitorização da glicemia capilar, foram digitados no programa Microsoft Excel, para a análise descritiva com freqüência numérica e percentual.

Os dados obtidos mediante a realização da entrevista foram transcritos integralmente e se realizou uma leitura exaustiva do material empírico. A seguir, foram selecionadas partes do material, procurando buscar as idéias relevantes que constituíram as unidades de significado, as quais foram codificadas e organizadas em categorias relacionando-as aos temas. A análise dos temas foi fundamentada nos documentos oficiais identificados através do levantamento acerca dos direitos do usuário em diabetes em saúde e dos princípios da Bioética.

\subsection{Aspectos éticos}

O projeto de pesquisa foi aprovado pelo Comitê de Ética em Pesquisa da Escola de Enfermagem de Ribeirão Preto da Universidade de São Paulo, atendendo 
à resolução 196/96 do Conselho Nacional de Saúde sobre Ética da Pesquisa em Seres Humanos, número de protocolo 0869/2008 (ANEXO).

Todos os participantes assinaram e receberam uma cópia do Termo de Consentimento Livre e Esclarecido. Em nosso estudo os nomes citados nas falas dos participantes foram traduzidos para nomes fictícios, respeitando-se o princípio do anonimato. 
5 RESULTADOS E DISCUSSÃO 
Os resultados serão apresentados de acordo com a caracterização dos participantes da pesquisa e a análise dos temas que emergiram das entrevistas.

\subsection{Caracterização dos participantes}

Dos 12 (100\%) usuários com diabetes entrevistados, 6 (50,0\%) eram do sexo masculino e $6(50,0 \%)$ do sexo feminino. A idade variou de 42 a 74 anos de idade, predominando $5(41,7 \%)$ pessoas na faixa etária de 60 a 69 anos, seguido de 4 $(33,3 \%)$ na faixa etária de 50 a 59 anos. Quanto à escolaridade, houve predomínio de $8(66,7 \%)$ usuários com o segundo grau completo e $8(66,7 \%)$ são casados. A renda familiar predominante foi de 4 (33,3\%) salários-mínimos, e 6 (50\%) participantes eram aposentados conforme Tabela 1. 
Tabela 1- Distribuição numérica e percentual dos sujeitos atendidos no Centro de Pesquisa e Extensão Universitária segundo o sexo, idade, escolaridade, estado civil, renda familiar, ocupação. Ribeirão Preto-SP, 2009.

\begin{tabular}{|c|c|c|}
\hline & \multicolumn{2}{|c|}{$\mathrm{n}=12$} \\
\hline Sexo & $n^{0}$ & $\%$ \\
\hline Feminino & 6 & 50,0 \\
\hline Masculino & 6 & 50,0 \\
\hline Total & 12 & 100 \\
\hline \multicolumn{3}{|l|}{ Idade } \\
\hline 40 a 49 anos & 1 & 8,3 \\
\hline 50 a 59 anos & 4 & 33,3 \\
\hline 60 a 69 anos & 5 & 41,7 \\
\hline 70 a 79 anos & 2 & 16,7 \\
\hline Total & 12 & 100 \\
\hline \multicolumn{3}{|l|}{ Escolaridade } \\
\hline $1^{\circ}$ grau completo & 3 & 25,0 \\
\hline $2^{\circ}$ grau completo & 8 & 66,7 \\
\hline $3^{\circ}$ grau completo & 1 & 8,3 \\
\hline Total & 12 & 100 \\
\hline \multicolumn{3}{|l|}{ Estado Civil } \\
\hline Casado & 8 & 66,7 \\
\hline Viúvo & 3 & 25,0 \\
\hline Divorciado & 1 & 8,3 \\
\hline Total & 12 & 100 \\
\hline \multicolumn{3}{|l|}{ Renda Familiar } \\
\hline 3 salários mínimos * & 3 & 25,0 \\
\hline 4 salários mínimos & 4 & 33,3 \\
\hline 5 salários mínimos & 3 & 25,0 \\
\hline 6 salários mínimos & 1 & 8,3 \\
\hline > que 7 salários mínimos & 1 & 8,3 \\
\hline Total & 12 & 100 \\
\hline \multicolumn{3}{|l|}{ Ocupação } \\
\hline Do lar & 4 & 33,3 \\
\hline Aposentado & 6 & 50,0 \\
\hline Assalariado & 1 & 8,3 \\
\hline Autônomo & 1 & 8,3 \\
\hline Total & 12 & 100 \\
\hline
\end{tabular}

* Salário mínimo vigente R\$ 465,00 calculado com base na Medida Provisória 456/2009, que dispõe sobre 0 salário mínimo a partir de $1^{\circ}$ de fevereiro de 2009 (http://www.planalto.gov.br).

Quanto ao tipo de diabetes, 9 (75\%) eram do tipo 2 (75\%), e 7 (58,3\%) tinham o tempo de diagnóstico entre 6 e 10 anos. Vale ressaltar que, dos 12 participantes entrevistados, $2(16,6 \%)$ não souberam informar o tipo de diabetes. No que se refere ao tipo de tratamento utilizado pelo usuário para o diabetes, 6 (50\%) utilizavam 
antidiabético oral; $16,6 \%$ insulina; $16,6 \%$ antidiabético oral associado com insulina e 16,6\% apenas com exercício físico e dieta (Tabela 2).

Em relação à maneira como os usuários obtinham os medicamentos, 50\% referiram adquirir os medicamentos nas Unidades Básicas de Saúde; 16,6\% nas UBS ou nas farmácias populares e 16,6\% em farmácias particulares ou farmácias dos convênios de saúde (Tabela 2).

No que diz respeito à instituição de saúde em que os participantes faziam seguimento para o controle do diabetes, 33,3\% o realizavam em Unidades Básicas de Saúde (UBS); 8,3\% em Unidades Básicas Distritais de Saúde (UBDS); 25\% apenas em serviços de convênios de saúde; e 33,3\% em UBS ou UBDS em conjunto com os serviços de convênios (Tabela 2). 
Tabela 2 - Distribuição numérica e percentual dos usuários com diabetes atendidos no Centro de Pesquisa e Extensão Universitária segundo o tipo de diabetes, tempo de doença, tratamento atual, forma como obtém os medicamentos e instituição de saúde em que realiza acompanhamento. Ribeirão Preto-SP, 2009.

\begin{tabular}{|c|c|c|}
\hline \multirow[b]{2}{*}{ Tipo de diabetes } & \multicolumn{2}{|c|}{$\mathrm{n}=12$} \\
\hline & $\mathbf{n}$ & $\%$ \\
\hline Tipo 1 & 1 & 8,3 \\
\hline Tipo 2 & 9 & 75,0 \\
\hline Não soube informar & 2 & 16,7 \\
\hline Total & 12 & 100 \\
\hline \multicolumn{3}{|l|}{ Tempo de doença } \\
\hline Até 1 ano & 1 & 8,3 \\
\hline 6 a 10 anos & 7 & 58,3 \\
\hline 11 a 15 anos & 4 & 33,3 \\
\hline Total & 12 & 100 \\
\hline \multicolumn{3}{|l|}{ Tratamento atual } \\
\hline Antidiabético oral & 6 & 50,0 \\
\hline Insulina & 2 & 16,7 \\
\hline Antidiabético Oral + Insulina & 2 & 16,7 \\
\hline Exercício Físico + Dieta & 2 & 16,7 \\
\hline Total & 12 & 100 \\
\hline \multicolumn{3}{|l|}{ Como obtém o medicamento } \\
\hline Unidade Básica de Saúde & 6 & 50,0 \\
\hline UBS ou Farmácia Popular & 2 & 16,7 \\
\hline Farmácia Particular/Convênio & 2 & 16,7 \\
\hline Não faz uso de medicamento & 2 & 16,7 \\
\hline Total & 12 & 100 \\
\hline \multicolumn{3}{|c|}{$\begin{array}{l}\text { Instituição de saúde em que realiza o } \\
\text { acompanhamento }\end{array}$} \\
\hline UBS + UBDS & 5 & 41,7 \\
\hline UBS/UBDS + Convênio & 4 & 33,3 \\
\hline Convênio & 3 & 25,0 \\
\hline Total & 12 & 100 \\
\hline
\end{tabular}

Em relação à monitorização da glicemia capilar, verificou-se que 50\% dos participantes realizavam a monitorização da glicemia, e 50\% não a realizam. 33,3\% dos usuários entrevistados possuíam o glicosímetro e recebiam as tiras para realização das glicemias capilares em domicílio; 16,7\% realizavam a monitorização da glicemia capilar nas unidades de saúde. Quanto à participação em programas educativos, constatou-se que a totalidade dos participantes nunca haviam participado de programa educativo. 
Tabela 3 - Distribuição numérica e percentual dos usuários com diabetes atendidos no Centro de Pesquisa e Extensão Universitária segundo realização de monitorização de glicemia capilar, recebimento de glicosímetro e fitas para glicosimetria e participação em programa educativo. Ribeirão Preto-SP, 2009.

\begin{tabular}{l|c|c}
\hline & \multicolumn{2}{|c}{$\mathrm{n}=12$} \\
\hline Monitorização de glicemia capilar & $\mathbf{n}$ & $\%$ \\
\hline Realiza & 6 & 50,0 \\
Não realiza & 6 & 50,0 \\
Total & 12 & 100 \\
\hline Recebeu glicosímetro na UBS & & \\
\hline Sim & 4 & 33,3 \\
Não & 8 & 66,7 \\
Total & 12 & 100 \\
\hline Recebe tiras para glicosimetria na & & \\
UBS & & \\
\hline Sim & 4 & 33,3 \\
Não & 8 & 66,7 \\
Total & 12 & 100 \\
\hline Participou de algum programa & & \\
educativo antes & & - \\
\hline Sim & - & 100,0 \\
Não & 12 & 100 \\
Total & & \\
\hline
\end{tabular}

$\mathrm{Na}$ análise das entrevistas realizadas com os usuários com DM emergiram três temas: a não consciência dos usuários com diabetes mellitus acerca dos seus direitos; a co-responsabilidade em saúde no que diz respeito ao fornecimento de informações e à efetivação dos direitos dos usuários com diabetes mellitus; a qualidade da interação profissional-usuário nos serviços de saúde, conforme Quadro 1 apresentado a seguir: 
Quadro 1- Temas e categorias encontrados nos depoimentos dos participantes.

\begin{tabular}{|c|c|c|}
\hline Temas & Categorias & \\
\hline \multirow{2}{*}{$\begin{array}{lrr}\text { A não-consciência } \\
\text { dos usuários com } \\
\text { diabetes mellitus } \\
\text { acerca dos seus } \\
\text { direitos }\end{array}$} & s direitos & E8. \\
\hline & $\begin{array}{l}\text { O exercício não-consc } \\
\text { pelos usuários com dia }\end{array}$ & $\begin{array}{l}\text { E1, E4, E7, E11, } \\
\text { E12, E9, E10, E5, } \\
\text { E3. }\end{array}$ \\
\hline \multirow{3}{*}{$\begin{array}{lr}\text { A co-responsabilidade } \\
\text { em saúde no que diz } \\
\text { respeito } \\
\text { fornecimento } \\
\text { informações e ao } \\
\text { efetivação dos direitos } \\
\text { dos usuários com } \\
\text { diabetes mellitus }\end{array}$} & $\begin{array}{l}\text { oder público na divulgação } \\
\text { jes }\end{array}$ & $\begin{array}{l}\text { E8, E10, E4, E7, } \\
\text { E1, E2, E9, E3, } \\
\text { E12, E6. }\end{array}$ \\
\hline & $\begin{array}{l}\text { As competência } \\
\text { dos profissionais } \\
\text { moral em inform }\end{array}$ & E10, E9, E6, E2. \\
\hline & $\begin{array}{l}\text { A p } \\
\text { nat }\end{array}$ & $\begin{array}{l}\text { E3, E9, E7, E4, } \\
\text { E2. }\end{array}$ \\
\hline \multirow{2}{*}{$\begin{array}{l}\text { A qualidade da } \\
\text { interação } \\
\text { profissional-usuário } \\
\text { nos serviços de } \\
\text { saúde }\end{array}$} & $\begin{array}{l}\text { A des(humanização) do atendimento nos } \\
\text { serviços de saúde }\end{array}$ & $\begin{array}{l}\text { E2, E10, E9, E1, } \\
\text { E4, E12, E7, E6, } \\
\text { E3. }\end{array}$ \\
\hline & $\begin{array}{l}\text { A percepção da necessidade de } \\
\text { transformação da prática assistencial }\end{array}$ & $\begin{array}{l}\text { E4, E9, E1, E11, } \\
\text { E10, E6. }\end{array}$ \\
\hline
\end{tabular}

\subsection{A não-consciência dos usuários com diabetes mellitus acerca dos seus direitos.}

Neste tema, de acordo com as falas dos participantes constatou-se, que a maioria desconhece os seus direitos. Por outro lado, parecem utilizar os seus direitos, sem a devida consciência do seu exercício. Portanto, as categorias que emergiram foram: o (des)conhecimento dos usuários com diabetes acerca dos seus direitos e o exercício não-consciente dos direitos pelos usuários com diabetes.

\subsubsection{O (des)conhecimento dos usuários com diabetes mellitus sobre seus direitos}

O princípio da autonomia, de acordo com Beauchamp e Childress (1979), assegura o direito das pessoas terem pontos de vista próprios, fazer escolhas, tomar 
atitudes baseadas em crenças e valores pessoais. Portanto, respeitar a capacidade de autonomia das pessoas significa prover toda a informação necessária para que a pessoa possa tomar a melhor decisão de acordo com o seu interesse.

Os dados do nosso estudo convergem para o desconhecimento dos usuários sobre seus direitos, fato este que pode ser verificado através da fala que se segue:

Meus direitos como usuário com diabetes? Olha eu não conheço nenhum direito. Eu não sei. (E4)

Em estudo realizado com o objetivo de compreender os motivos que levavam enfermeiras a interferirem na capacidade de autonomia de usuários com doenças crônicas, observou-se que dentre os motivos tem-se o não reconhecimento da capacidade de autonomia dos clientes; o desconhecimento dos usuários de seus direitos; o perfil de dependência dos clientes, dentre outros (COSTA, LUNARDI, LUNARDI FILHO, 2007).

Assim, é possível observar que, ainda parece haver carência de informações para que esses usuários do SUS possam, mediante o conhecimento de seus direitos, vir a exercê-los enquanto cidadãos, em um contexto onde a justiça e a equidade sejam pressupostos fundamentais para a correção das desigualdades na saúde. Para tanto, Pellegrini Filho (2004) defende a tese de que a informação e o conhecimento são bens públicos essenciais, e que as desigualdades de acesso a esses bens são importantes determinantes das possíveis iniqüidades em saúde.

No caso brasileiro, o desafio que se coloca é o de materializar em práticas as conquistas estabelecidas no plano legal (BOSI; AFFONSO, 1998). Dentro do que se denomina processo de construção dos direitos em saúde, destacamos dois aspectos como fundamentais: o primeiro deles, a construção de uma consciência sanitária entendida como "a tomada de consciência de que a saúde é um direito da pessoa" (BERLINGUER, 1978, p.50); o segundo aspecto, intrinsecamente associado ao primeiro, a participação popular como mecanismo fundamental no referido processo. 
Em nosso estudo, entretanto, foi possível perceber que os entrevistados desconhecem a legislação vigente referente ao que os usuários com diabetes podem usufruir nos sistemas de saúde.

Eu até te confesso que eu nem sabia que eu tinha direito. Então eu não posso conhecer nada, porque eu não sei nem quais são os direitos que eu tenho enquanto diabético. (E6)

O Projeto Saúde, realizado pelo Ministério da Saúde em conjunto com a Fundação Oswaldo Cruz e a Organização Pan - americana de Saúde, com o objetivo de contribuir para a ampliação da visão dos problemas relativos ao cuidado à saúde do cidadão brasileiro, aponta para o desconhecimento dos usuários quanto aos seus direitos (BRASIL, 2003b). Na pesquisa referida o desconhecimento dos usuários estaria associado a uma lógica clientelista no SUS, conforme o que se pode ver:

...há uma grande ignorância sobre o sistema e, por outro, sendo o SUS uma política de direito social, não interessa informar; em termos da consciência do cidadão sobre seu direito, o discurso sanitário brasileiro é uma reserva de poder para pequeno grupo de iniciados e para o público em geral não é acessível, inteligível (BRASIL, 2003, p.25).

Dessa maneira, a fala que se segue parece estar em concordância com os achados do Projeto Saúde 2004 (BRASIL, 2003b). O usuário a seguir, assim como outros, refere não ter recebido informações sobre seus direitos como usuário com diabetes:

Nada, ninguém me falou, nunca, nada sobre isso meus direitos como diabético. (E9) 
Além disso, a falta da "concretização dos direitos que não saem do papel" aparece na fala do usuário a seguir, assim como a percepção de que no Brasil há iniqüidades no que tange a distribuição de bens em saúde (BOSI; AFFONSO, 1998, p.360).

Bom, se for ver a constituição brasileira eu tenho todo direito a saúde, e na realidade eu não tenho. A saúde no Brasil é um caos total, e aqui ainda é bom, é melhor um pouco. Mas você vai por aí, a coisa é triste. (E2)

Assim temos com Pellegrini Filho (2004, p. 342) que:

As iniqüidades de acesso a conhecimentos e informações são especialmente dramáticas, pois ao reforçar a exclusão, têm um enorme poder de gerar e ampliar outras iniqüidades. No caso da saúde, as iniqüidades de informação podem ser consideradas um importante determinante das iniqüidades de saúde, na medida em que o acesso iníquo a conhecimentos e informações prejudica a atuação individual e coletiva dos membros de uma sociedade para a mudança de estruturas, comportamentos e políticas. O acesso universal à informação deve, portanto ser parte essencial do processo de definição de políticas de saúde voltadas para a eqüidade.

Portanto, a democratização do conhecimento entendida desta maneira pode "empoderar" os cidadãos, permitindo que participem das decisões relativas à definição e implantação de políticas que lhes garantam o alcance ao direito à saúde (SELLI; VIAL, 2006). A partir da informação então, é possível julgar situações, assumir condutas e exercer direitos como pessoas pró-ativas, autônomas e cidadãs. A fala a seguir exemplifica a percepção que o usuário possui sobre a importância de se conhecer direitos para se posicionar de maneira autônoma: 
Quando a gente tem conhecimento dos nossos direitos a gente tem mais autonomia para reivindicar. A gente só reivindica o que a gente conhece que é de direito nosso, não é? Por isso que eu acho que todo mundo tem que ter acesso a essas informações, sobre os nossos direitos. (E4)

Trata-se, então, de "viabilizar a igualdade para todos na possibilidade de desenvolverem sua autonomia ética", fornecendo subsídios à sociedade através da disponibilização das informações em saúde, para que todos possam exercer seus direitos e não somente os mais favorecidos (SELLI; VIAL, 2006). Isso pôde ser percebido através da fala que se segue:

A gente exerce os direitos da gente quando a gente tem o conhecimento, se não tem o conhecimento você não pode exigir aquilo que você não conhece. A mesma coisa de dar o que você não tem informação. Se você não tem informação, você nem usufrui do direito e nem pode passar pro outro porque você não tem a informação. $A$ pessoa fica sem saber e não sabendo ela não sabe o que ela deve fazer ou deixar de fazer. Ela se torna dependente de alguém que saiba, ou então não vai saber nunca. Ela não é livre pra decidir, ela não sabe nem entre o que ela pode decidir, o que ela pode escolher. A informação é o ponto chave, depois que a pessoa tem o conhecimento, aí sim ela tem condição de optar pelo sim ou pelo não, de querer tentar conseguir o medicamento gratuito ou de querer comprar. Mas ela tem que ter o conhecimento pra optar. (E8)

Na percepção do usuário a seguir, o conhecimento sobre os direitos confere aos usuários a possibilidade de ser digno de ao menos receber uma satisfação, quando, por exemplo, ocorre a falta de medicamentos: 
Eu sinto que tem pessoas, que às vezes se ela não tiver um pouquinho de conhecimento... Eles (profissionais da farmácia) atendem bem, mas também se a pessoa (usuário de saúde) às vezes fala 'e quando é que vai chegar?' Eles (profissionais da farmácia) falam: 'Não sei, espera'. Também não é assim, né? Se é direito de cidadão tem que dar uma satisfação, dizer: "olha vai chegar tal dia”. Eu vejo que se você não tiver um pouquinho de conhecimento ali, aí já é mais problemático. (E4)

Assim, o direito dos usuários em ser informado sobre os motivos do atraso na dispensação dos medicamentos/insumos está contemplado na lei 11.347/06, que dispõe sobre a distribuição gratuita de medicamentos e materiais necessários à sua aplicação e à monitoração da glicemia capilar aos usuários com diabetes inscritos em programas de educação para pessoas com Diabetes mellitus. Nesse sentido, a lei 11.347/06 diz em seu Art. $3^{\circ}$ que:

É assegurado ao diabético o direito de requerer, em caso de atraso na dispensação dos medicamentos e materiais citados no art. $1^{\circ}$, informações acerca do fato à autoridade sanitária municipal.

No entanto, apesar dos avanços do SUS desde sua criação, "o Estado ainda falha em garantir o acesso da população brasileira aos medicamentos essenciais" (VIEIRA; ZUCCHI, 2007, p. 216). Com isso, atualmente, um fenômeno vêm ocorrendo reiteradamente no país: a judicialização da saúde. Tornou-se freqüente a reivindicação por parte dos usuários, via judiciário, para a aquisição de medicamentos excepcionais (de alto custo) e algumas vezes os essenciais, que deveriam estar disponíveis na rede básica de assistência à saúde (VIEIRA; ZUCCHI, 2007). Na fala a seguir, o usuário revela a instauração de um processo jurídico através do Ministério Público, com o objetivo de obter a insulina Glargina do Estado, necessária ao seu tratamento. Essa não faz parte da Relação de Medicamentos de Dispensação Excepcional e possui um custo elevado. 
Segundo essa médica que eu fui, essa última médica, ela me falou que pode se conseguir a insulina, certo? Então, lá no Ministério Público, eu dei entrada, não sei se eu vou conseguir, né? (E8)

Para tanto, A OMS (2002a) define medicamentos essenciais como aqueles que "satisfazem às necessidades de saúde prioritárias da população, os quais devem estar acessíveis em todos os momentos, na dose apropriada, a todos os segmentos da sociedade". Enquanto os medicamentos denominados excepcionais, de dispensação em caráter excepcional ou de alto custo, são aqueles medicamentos cuja aquisição, governamental, é feita em caráter excepcional, individual, e com recursos financeiros independentes daqueles destinados aos medicamentos da Relação Nacional de Medicamentos Essenciais, utilizando critério especial para dispensação (SILVA, 2000).

Vale destacar que, após a instituição da Política Nacional de Medicamentos, as competências de cada nível de gestão foram definidas de modo a haver uma ação coordenada entre os três níveis de gestão da saúde. Assim, à gestão municipal cabe a responsabilidade de executar as ações, incluindo a dispensação de medicamentos essenciais financiados pelo município; à gestão estadual cabe a responsabilidade de organizar e coordenar as ações de assistência farmacêutica dentro do Estado, além da responsabilidade especifica quanto à dispensação de medicamentos de alto custo ou excepcionais. Por fim, à gestão federal cabe regular todo o sistema, providenciar os mecanismos de financiamento, bem como propor as diretrizes das ações a serem implantadas pelos Estados e Municípios (BRASIL, 1999).

Fica claro, então, que a Judicialização da Saúde diz respeito ao papel do Poder Judiciário, que em um Estado constitucional democrático, consiste em interpretar a Constituição e as leis, e resguardar direitos, além de assegurar o respeito ao ordenamento jurídico (BARROSO, 2008). Nesse caso, temos que a saúde é um direito de todos e dever do Estado, assegurado constitucionalmente, e o judiciário,por sua vez, atua em uma arena que requer a proteção dos princípios constitucionais, em outras palavras, a proteção dos direitos dos usuários legitimados pela Constituição de 1988. 
Um estudo sobre as características da judicialização do direito à saúde no Brasil, que abrangeu mais de 10.000 casos, em cinco Estados brasileiros, no período de 1994 a 2004, demonstrou que somente 2\% dos processos eram coletivos, predominando as ações de pessoas físicas contra o Estado em busca de medicamentos ou tratamentos médicos. Dentre os medicamentos solicitados, muitos são classificados pelo SUS como "excepcionais" e associados a condições crônicas. Por fim, o estudo conclui que há um considerável impacto financeiro dessas decisões (SILVA, 2007).

Dessa forma, gastos extras do Ministério da Saúde com remédios concedidos judicialmente para todos os tipos de doença aumentaram de 188 mil reais em 2003 para 26 milhões de reais em 2007. Em 2004, o Estado de São Paulo despendeu 48 milhões de reais com medicação ganha em litígio, de um orçamento para a saúde total de 480 milhões de reais. O Ministério da Saúde calcula que, em todos os Estados, gastos extras associados a litígios tenham sido, só em 2007, no montante de R\$1 bilhão. São remédios de alto custo e tratamentos de longo prazo de doentes crônicos que elevam esses valores (HOFFMAN; BENTES, 2008).

Com o objetivo de descrever os efeitos das ações judiciais que requerem o fornecimento de medicamentos, em relação a aspectos da política nacional de medicamentos, um estudo foi realizado durante o ano de 2005. Foram analisados todos os processos movidos por cidadãos contra a Secretaria Municipal de Saúde de São Paulo e observou-se que o diabetes foi a doença mais referida nas ações judiciais totalizando 37\% das ações (VIEIRA; ZUCCHI, 2007).

Temos, então, com o estudo de Vieira e Zucchi (2007) que 40,8\% da origem das prescrições de ações judiciais contra a Secretaria Municipal de Saúde de São Paulo, no ano de 2005, foram provenientes de serviços privados. Como encontramos em nosso estudo o usuário entrevistado, que faz seu acompanhamento em convênio de saúde, e recebeu a prescrição da insulina Glargina, um medicamento de alto-custo em diabetes.

De acordo com Barroso (2008), a intervenção do Poder Judiciário, mediante determinações da Administração Pública para que forneça gratuitamente medicamentos em uma variedade de hipóteses, procura realizar a promessa constitucional de prestação universalizada do serviço de saúde. Assim, temos que: 
Alguém poderia supor, a um primeiro lance de vista, que se está diante de uma colisão de valores ou de interesses que contrapõe, de um lado, o direito a vida e a saúde e, de outro, a separação de Poderes, os princípios orçamentários e a reserva do possível. A realidade, contudo, é mais dramática. O que está em jogo, na complexa ponderação aqui analisada, é o direito à vida e à saúde de uns versus o direito à vida e à saúde de outros. Não há solução juridicamente fácil nem moralmente simples nessa questão. Sempre que a Constituição define um direito fundamental ele se torna exigível, inclusive mediante ação judicial (BARROSO, 2008, p.4).

Esse conjunto demonstra que, apesar da jurisprudência ter-se orientado por uma interpretação favorável à eficácia das normas constitucionais de saúde, o modo como se desenvolveu a judicialização do direito à saúde no Brasil permite a determinados indivíduos - muitas vezes de classes abastadas - ter acesso a benefícios que não são oferecidos para toda a população, prejudicando a eqüidade e a eficiência do sistema público. Na raiz dessas dificuldades, encontra-se uma compreensão imperfeita dos princípios que regem às políticas de saúde no Brasil. Portanto, o aprofundamento da reflexão sobre a exigência judicial do direito à saúde deve partir da análise da organização institucional do sistema público de saúde. Essa análise deve levar em consideração a escassez dos recursos disponíveis e a conseqüente necessidade de estabelecer prioridades no gasto público, instrumentos indispensáveis para o planejamento adequado de políticas que visem à universalização dos direitos sociais (LOPES, 2006; SILVA, 2007b).

Deste modo, a Judicialização do direito à saúde deve transcender as causas individuais e permitir que o judiciário colabore com a distribuição mais eqüitativa dos bens relacionados à saúde, cumprindo com sua função de garantir os direitos fundamentais (MAUÉS, 2003).

Diante do exposto, em nosso estudo, parece evidente que há desconhecimento pela maioria dos usuários com diabetes, sobre seus direitos à saúde e sobre a legislação vigente sobre DM. Em contrapartida, foi possível verificar que, a maioria dos usuários com diabetes mellitus utiliza os benefícios advindos da legislação sobre DM, de maneira não consciente. 


\subsubsection{O exercício não-consciente dos direitos pelos usuários com diabetes mellitus}

Tendo em vista o princípio Bioético da justiça, de acordo com Beauchamp e Childress (1979), temos que o reconhecimento do direito obrigatório a um mínimo de assistência à saúde pode assegurar a distribuição justa dos recursos em saúde, além de incorporar de modo coerente os padrões utilitaristas e igualitários, os quais norteiam nosso sistema de saúde. Dessa forma, tal princípio prevê que todos os usuários de saúde devem ter acesso igual aos serviços de saúde e as mesmas oportunidades de acesso às informações que lhes são necessárias para a promoção, prevenção e recuperação da saúde.

Embora, 10 (83\%) dos entrevistados tenham referido (des)conhecimento com relação aos direitos dos usuários com diabetes, alguns no decorrer da entrevista demonstraram o reconhecimento de seus direitos, como identificado nas falas que se seguem:

Eu não tô sabendo de nada ainda... Silêncio... Ah eu acho que pegar a insulina lá no postinho, né? E as fitas, né que eu pego. (E1)

Não sei... Acho que os medicamentos, consultas no posto de saúde, que eu saiba é mais ou menos isso, eu penso. (E4)

Direitos... Olha, tem direito a fazer o tratamento digno, seria o acompanhamento, ou seja, em clínica particular, ou seja, através do SUS, é um direito adquirido do programa do governo, esses seriam os direitos. (E7) 
O padrão de utilização de serviços de saúde de um determinado grupo populacional é predominantemente explicado por seu perfil de necessidades em saúde (HULKA; WHEAT, 1985). A disponibilidade, o tipo, a quantidade de serviços e recursos (financeiros, humanos, tecnológicos), a localização geográfica, a cultura médica local, a ideologia do prestador, entre outros, são aspectos da oferta dos serviços de saúde que influenciam o padrão de consumo dos indivíduos (WENNBERG, 1985).

Assim sendo, temos com a fala a seguir a percepção do usuário que discorre sobre a aquisição de informações que foram obtidas em um processo educativo:

Olha, segundo que tenho aprendido no grupo, o diabético agora têm direitos adquiridos nessa área. A gente tem direito nos aparelhinhos (glicosímetros), direitos aos medicamentos, prioridades em consultas, e eu acho que é, as coisas básicas né, do diabético. (E11)

Por outro lado, as escolhas individuais também são importantes, uma vez que nem todas as necessidades individuais se convertem em demandas para os serviços de saúde e nem todas as demandas são atendidas (GAIOSO, 2007). Assim, nem todos os usuários têm as mesmas necessidades e, portanto desfrutam de formas diferentes dos benefícios que lhes são assegurados, conforme a seguir:

Direitos? Eu sei que eles dão os remédios de graça, mas só que eu nunca fui atrás, porque eu compro, né? Eu prefiro comprar e deixar esses (medicamentos) que o governo dá pra quem não tem condições para comprar, né?(E12)

De uma maneira implícita, a fala acima demonstra um sentimento de solidariedade para com os menos favorecidos economicamente, ao mesmo tempo em que é possível perceber certa "naturalização de tal situação pelos usuários, que 
terminam por reconhecer o serviço disponível como um favor ou doação e não como um direito" (TRAVERSO-YÉPEZ; MORAIS, 2004, p.84). O sentimento de gratidão, segundo Bernhart (1999) seria comum em países periféricos.

Segundo Anjos (2001, p.38), "mais que configurados os direitos necessitam ser acessíveis e materializáveis". A fala que se segue parece ilustrativa nesse sentido, os usuários utilizam o que lhe são de direito, conforme o previsto na lei 11.347/06 e Relação Nacional de Medicamentos Essenciais:

Eu pego a Insulina no posto, pego as seringas no posto, pego o ASS (ácido acetil salicílico) no posto, mas só o glifage XR (retard) que eu não pego, se fosse o glifage normal eles davam, mas como é o XR (retard), que ela receitou, eles não dão. (E9)

A única coisa que eu sei que eu tenho direito é a medicação. Eu pego o remédio no posto. Eu tenho uma sobrinha que o diabetes dela é bem forte, e ela não gasta nada pra tratar, ela ganha as agulhinhas, as fitas e até o aparelhinho, eles dizem que quando o diabetes é forte do jeito do dela, aí eles dão o aparelhinho, mas como o da gente é controlado, eles não dão esse aparelho. (E13)

Assim, ao se pensar no manuseio da informação adquirida, temos com Marchi (1998) que, a capacidade de agir significa capacidade para o exercício de direitos. Capacidade esta que vai além da busca de informações, mas objetiva a resolutividade dos problemas relacionados à saúde. Importante ressaltar que, capacidade jurídica significa a capacidade de gozo de direitos, isso quer dizer que, legalmente o direito à saúde existe e, portanto todas as pessoas têm capacidade jurídica de desfrutar ou não desse direito.

A fala a seguir expõe outra conduta do usuário de saúde que é consciente de seus direitos e, expressa sua capacidade de agir: 
Eu já peço e falo: "eu tenho direito a isso e eu quero, porque é um direito meu", se não fosse ficava quieto. (E4)

Em estudo realizado por Mafra (2007) com o objetivo de analisar as trajetórias dos usuários de Itajaí - SC que receberam medicamentos via mandatos judiciais contra o Estado de Santa Catarina, bem como suas motivações e percepções sobre essa forma de acesso aos medicamentos, observou-se que as trajetórias desses usuários revelaram as tentativas de busca pelo medicamento através de políticos e da assistência social, conforme as falas que apresentamos a seguir:

A médica do posto é candidata a vereadora lá na cidade, então ela já passou uma receita pra seis meses. Então, durante seis meses eu vou lá e pego (medicamento). Vale por seis meses. (E4)

Porque agora ó, época de eleição, o que você precisar, você consegue. Você vai num político, você fala ó, eu precisaria disso, aí eles dizem: "eu vou te arrumar", principalmente aqueles que são médicos, né? Então eu vejo que existe um interesse por trás das coisas, sempre tem um interesse. (E5)

De acordo com Mafra (2007), tais relações entre políticos, médicos e usuários de saúde revelam a percepção pelo usuário de que um "favor" de uma pessoa foi motivador para a concessão de benefícios. Assim, é necessário que haja a interferência de alguém para que se consiga alcançar benefícios legalmente já assegurados, mas não presentes na consciência desses usuários como direito, mas como "favor". Com isso, a conscientização dos direitos dos usuários com diabetes, não se encontra plenamente absorvida entre eles.

Além disso, outro usuário com diabetes, não consciente de seus direitos, se vale de relações pessoais de amizade para alcançar o que se deseja. Isso parece refletir um modelo pré-estabelecido nas instituições brasileiras e arraigado na cultura 
popular, onde o "jeitinho brasileiro" é utilizado como meio para se obter benefícios (DAMATTA, 1997, DAMATTA, 2000).

Chegar até o prefeito mesmo, graças a Deus eu tenho essa "boa sorte"... Risos... Eu posso chegar e falar diretamente com ele se eu quiser, ele me conhece, nós somos amigos e estudamos juntos. (E3)

Assim, faz-se necessário salientar que, há a urgente necessidade de favorecer a conscientização dos usuários com diabetes sobre seus direitos, sobretudo no que se refere ao entendimento de que os benefícios existem e devem ser entendidos não como "favores", mas como fruto decorrente de uma política de saúde que prevê e dispõe de instrumentos legais para sua concretização. Para tanto, a informação é imprescindível nesse processo que tem por objetivo informar os usuários com diabetes sobre seus direitos e desenvolver a efetivação dos direitos desses usuários.

\subsection{A co-responsabilidade em saúde no que diz respeito ao fornecimento de informações e à efetivação dos direitos dos usuários com diabetes mellitus}

Neste tema foi possível perceber, de acordo com as falas dos entrevistados, que existem responsabilidades as quais devem ser compartilhadas entre o governo, os profissionais de saúde e os usuários de saúde com DM. O cumprimento de tais responsabilidades por todos os envolvidos pode resultar no pleno exercício dos direitos.

Dessa forma, as categorias que emergiram foram: o papel do poder público na divulgação das informações; as competências e responsabilidades dos profissionais de saúde: dever ético-moral em informar e a participação ou isenção dos usuários na busca por informações. 


\subsubsection{O papel do poder público na divulgação das informações}

Por autonomia, princípio básico da Bioética entende-se o autogoverno, a autodeterminação da pessoa em tomar decisões relacionadas à sua vida, sua saúde, sua integridade físico-psiquíca e suas relações sociais, presumindo a existência de opções, liberdade de escolha e requerendo que o indivíduo seja capaz de agir de acordo com as deliberações feitas (BEAUCHAMP; CHILDRESS, 1979).

Diante do contexto de saúde atual, no qual a saúde é um direito de todos e dever do Estado, é possível notar através da fala a seguir que há a necessidade de divulgação da informação relacionada aos direitos dos usuários pelo governo.

Eu acho que deveria ter uma melhor divulgação, uma divulgação precisa. Porque quem não tem conhecimento não pode ir atrás do que não conhece! Ele só vai atrás quando ele é informado (E8).

Importante é destacar que na percepção do usuário em questão a atitude de exercer direitos está atrelada ao conhecimento desses direitos. Tal fala expressa necessidades que vão de encontro ao que Veloso e Ferreira (2007), pressupõem ao partir do princípio que uma pessoa ao não ter clareza sobre os seus direitos, pode vir a ter limitações no exercício de sua cidadania.

Nas sociedades modernas, estruturadas como democracias representativas, todos os direitos, de alguma forma, relacionam-se com o direito à informação. Com isso, pressupõe-se que o alargamento do direito à informação pode resultar em um alargamento no exercício da cidadania. Assim, a informação representa um pressuposto básico para o processo de construção de uma sociedade democrática (GENTILLI, 2005).

Em um estudo realizado no Rio de Janeiro com o objetivo de caracterizar as representações sociais da cidadania por usuários de um serviço de saúde e compreender suas ações frente ao que Ihes é oferecido, as autoras concluem que 
as representações sociais da cidadania, de acordo com os resultados do estudo, estão relacionadas ao conhecimento que esses usuários possuem sobre normas, regulamentos e leis (VELOSO; FERREIRA, 2007). Assim sendo, temos com Pinsky e Pinsky (2003), que a cidadania configura "a expressão concreta do exercício da democracia".

Para a ordem jurídica, a informação é o pressuposto inerente para que o indivíduo realize suas escolhas no contexto de uma coexistência equilibrada em sociedade (MARCHI; SZTAJN, 1998). Assim sendo, vontade e capacidade parecem não ser suficientes para o pleno exercício da autonomia.

O entendimento de que o acesso à informação é uma porta de acesso a outros direitos nos leva a pensar que, sendo a saúde um direito social garantido constitucionalmente, é função do Estado prover e garantir o acesso às informações relativas ao SUS, dentre essas os direitos dos usuários envolvidos no processo de saúde-doença (GENTILLI, 2005).

De acordo com a Associação Brasileira de Pós-Graduação em Saúde Coletiva (ABRASCO) (1994), o acesso à informação constitui um dos alicerces do projeto de conquistas sociais e de construção da cidadania. Assim temos que, o acesso à informação pode potencialmente vir a consistir num direito que assegurará outros direitos, conferindo condições de igualização de sujeitos diante das políticas de saúde. Isso quer dizer que, se todos dispuserem da mesma informação, todos poderão mobilizar os recursos necessários para o exercício da autonomia, além de estabelecer uma rede de comunicações efetiva para a difusão das informações em saúde. A fala abaixo é esclarecedora nesse sentido:

As informações deveriam ser divulgadas nos veículos de comunicação de massa, que atinjam a maior quantidade de pessoas, para que todos ficassem sabendo. Se tivesse isso aí depois cada um passa pro outro, quer dizer família, colegas, amigos e assim vai se ampliando o conhecimento. (E8) 
Tendo em vista a importância da informação, como recurso na busca de pessoas autônomas e conseqüentemente, a efetivação do exercício dos direitos pela sociedade, a questão que emerge está relacionada com as responsabilidades sobre essa informação. Através das falas que se seguem, é possível apreender que há uma expectativa por parte dos usuários em relação ao poder público no que se refere à divulgação de informações e a utilização dos veículos de comunicação para isso:

O governo deveria correr atrás disso de divulgar, orientar e ajudar as pessoas (E10).

Os órgãos responsáveis, porque se ele tá dando esse direito a população ele também deveria divulgar melhor. Porque senão só quem sabe, que é orientado, usufrui desse direito, se é que tem! (E8)

O próprio governo devia usar os meios de informações, veículos de comunicação, né? No caso jornal, televisão, rádio. (E4)

Eu acho que deveria ter uma campanha no rádio, na televisão que diabético tem direito a esses medicamentos, que tem muita gente, é remédio no posto. (E7)

A esse respeito temos que os meios de comunicação são verdadeiros agentes da participação social e a imprensa seu esteio principal. Assim, destacamos o importante papel, por exemplo, do rádio no Brasil. Esse está presente em cerca de $90 \%$ dos lares e é acessível à quase totalidade da população. Portanto, trata-se de fornecer subsídios para que esses profissionais de comunicação do nosso país se sintam capazes de discutir questões relativas às políticas públicas instituídas, com o 
intuito final de democratizar a informação em saúde e desenvolver o exercício da cidadania (BRASIL, 2007c).

Além disso, é possível notar que há certa desconfiança do usuário relacionada ao fato de que talvez não seja interesse do governo propagar informações relacionadas aos direitos dos usuários em saúde, conforme expresso na fala que se segue:

Mas eu acho que isso também depende dos nossos governos, que não estão nem aí pro povão e que não estão interessados em fazer divulgação dos direitos do povo, né? (E1)

As falas dos entrevistados transpareceram a carência de informação dos usuários, os quais assumiram a posição de receptores de informações. Além disso, percebe-se que houve responsabilização das instâncias governamentais pela falta sentida pelos usuários de divulgação de informações sobre os direitos dos usuários com diabetes. No entanto, outros atores estão envolvidos no processo de (des)informação sobre direitos dos usuários como, por exemplo, os profissionais de saúde e os próprios usuários dos serviços de saúde brasileiro.

Faz-se indispensável salientar que, somente a informação sobre os direitos não resulta no pleno exercício dos mesmos pelos usuários com diabetes, é necessário que exista provisão de recursos por parte do Estado, bem como a sua adequada alocação e otimização, para que a utilização dos benefícios seja alcançada de forma justa e eqüitativa. Nisso consiste o conceito de Justiça Distributiva sob o qual o SUS foi ordenado (MARQUES; DALLARI, 2007).

Em estudo realizado em Francisco Morato, São Paulo, com objetivo de avaliar a assistência à população usuária do Programa de Saúde da Família, dos 72 entrevistados, 31,2\% estavam insatisfeitos. Dentre os principais motivos para a insatisfação, tem-se a falta de medicamentos (PAIVA; BERSUSA; ESCUDER, 2006). 
Tem hora que você vai no posto e não tem nem remédio, você tem que esperar. Nem o mínimo ele (governo) faz. (E2)

... Mas é isso, muitas vezes você vai pegar o remédio no posto e eles (atendentes da farmácia) falam que não tem. Eles falam: "O Sr volta daqui vinte dias". Agora eu posso esperar vinte dias? Isso é um absurdo ouvir isso, não é? (E8)

Conforme os artigos $6^{\circ}$ e $7^{\circ}$ da Lei Orgânica de Saúde $n^{\circ} 8.080$ de 19 de setembro de 1990, a assistência terapêutica e farmacêutica deve ser assegurada integralmente aos cidadãos brasileiros, de acordo com o princípio da integralidade do Sistema Único de Saúde. Ademais, a lei 11.347 garante a assistência terapêutica e farmacêutica aos usuários com diabetes incluindo medicamentos e insumos necessários ao tratamento desses usuários (BRASIL, 1990a; BRASIL, 2006b).

Diante da falta de medicamentos, os usuários com diabetes recorrem a alternativas que implicam em custos adicionais. Dos doze entrevistados, oito afirmaram receber gratuitamente o medicamento nas unidades de saúde, quando esse se encontra disponível o serviço. Porém, quando por algum motivo há falta de medicamentos, os mesmos compram ou buscam em unidades vizinhas. Tal fato vai de encontro aos resultados obtidos no estudo de Paiva, Bersusa e Escuder (2006), no qual os indivíduos quando na falta de medicamentos disponíveis nas unidades de saúde, compram o medicamento, procuram em unidades próximas ou esperam o medicamento chegar. As falas a seguir são representativas do que ocorre e demonstram as dificuldades enfrentadas por esses usuários no momento da falta de medicamentos ou insumos:

Eu vou no posto e não é toda hora que tem remédio, então eu preciso comprar, né? (E7) 
Ahh, não chegou. Aí eu sou obrigado a ir num outro posto, chega lá eles falam nós temos esse (medicamento), mas não temos o outro. Então é uma dificuldade. (E4)

Ahh, essa gente que não pode comprar, geralmente, eles sofrem porque às vezes eu vejo até pessoas tendo que pedir dinheiro pra outras pessoas para poderem comprar. Porque ela não tem o medicamento que ela precisa, ela não tem dinheiro, como é que ela faz? Então ela tem que pedir pra alguém, um auxílio. (E9)

Importante ressaltar que, dentre as medidas a serem tomadas com o objetivo de promover a melhoria da atenção à saúde: a ampliação do acesso da população aos medicamentos fornecidos pelo SUS, em especial aos medicamentos utilizados para o controle da hipertensão arterial e diabetes mellitus, tem seu respaldo no Programa mais saúde: Direito de Todos. Para tanto, tal programa objetiva aproveitar as potencialidades oferecidas pelo setor saúde como um dos elos vitais para um novo padrão de desenvolvimento brasileiro, enfrentando os enormes desafios ainda presentes. O programa contempla 73 medidas e 165 metas com um gasto total previsto de $\mathrm{R} \$ 89,4$ bilhões de reais. Esse conjunto de iniciativas permite consolidar a percepção estratégica de que a Saúde constitui uma frente de expansão que vincula o desenvolvimento econômico ao social (BRASIL, 2008).

Embora tais iniciativas configurem uma preocupação em ascensão com os problemas de saúde da população, e em especial dos usuários com DM, percebe-se uma aparente desconfiança dos usuários em relação à distribuição equitativa de bens, bem como a alocação de recursos. As falas abaixo, demonstram preocupação com o desvio de recursos da saúde, pelo poder público, além de transparecer solidariedade para com os menos favorecidos:

É o que a gente vê aí, todo mundo consegue desviar dinheiro. Eles (governantes) têm que parar de roubar! Ser mais justo, ser mais 
honesto. Aí eu acho que vai, porque aí chega em todos os lugares as coisas direitinho. Os nossos governantes estão sendo um pouco desumanos com o ser humano. Eles compram aqui e ali, mas em certos lugares as coisas não chegam... (E3)

As coisas não chegam em certos lugares. A gente sabe que aqui no estado de São Paulo tem, mas vai lá saber se em Manaus, no Acre, na Bahia, vai lá saber se tem alguma coisa! Tem alguma coisa, algum remédio? Você tá me entendendo? Se parasse com isso nós teríamos uma saúde melhor pra todos. Então sempre é aquele maldito desvio, que hoje todo mundo vê. (E12)

Eles (governantes) dizem que faz. Mas a gente não sabe se chega. É caminhão que rouba, é desvio que não foi, é isso, é aquilo. No fim você só vê isso, manipulação! Entre eles (governantes) cada um quer pegar mais que o outro, aí pega. Vai outro e cagueta ele e aí vira aquela confusão na mídia. Mas o mais importante é que aquele desvio não retorna pra população, e assim, mais uma vez as coisas não chegam na mão de quem precisa, do povo. Eles ficam naquele bate-boca, envergonham o país todo. É porque a gente aqui não vê isso tudo tão de perto, mas a gente sabe que em outros estados as coisas não são como aqui, o povo passa necessidade até de comida, criancinha ainda morrendo no nosso país! Sabe, aí eles falam: mas foi mandado tantos milhões de recursos para lá, mas chegou quando? Tá na mão de quem? Onde tá? É isso que eu falo, que não dá... Eu acho que os nossos governantes têm que olhar mais pra gente, porque é assim enquanto na minha casa tiver arroz e feijão e na do vizinho não tem, eu não tô nem aí... Nós deixamos de ser humano. Enfim esse negócio de solidariedade só sai da gente, deles lá (governantes) eu não espero mais nada. (E3) 
Nós vivemos num país em que a corrupção é o que mais impera, né? Você vê que hoje em dia, dinheiros que são desviados, que poderiam ser aplicados tanto em saúde, educação e, no entanto, não são né? (E6)

Assim, de acordo com Drane e Pessini (2005, p.216):

Por maior que seja o racionamento decretado, não se fornecem igualitariamente benefícios de saúde a todas as pessoas. Os ricos, os socialmente bem relacionados, as celebridades, os menos honestos sempre acham um meio de contornar o racionamento por mais que o sistema tente promover a equidade.

Nesse contexto, cabe à administração pública organizar os serviços, visando atender, de forma integral e universal, o direito à assistência farmacêutica e terapêutica dos usuários, bem como os demais direitos relacionados à saúde (MARQUES; DALLARI, 2007). Assim, é função dos profissionais de saúde fornecer as informações necessárias para que o atendimento em saúde seja eficaz e resulte no pleno exercício do direito desses usuários, contribuindo para a formação da cidadania dos usuários com DM.

\subsubsection{As competências e responsabilidades dos profissionais de saúde: dever ético-moral em informar}

A necessidade de prover informação adequada aos usuários remete ao papel social da equipe multiprofissional de saúde e configura a exigência prevista no principio bioético da Beneficência. Assim, informar os usuários dos serviços de saúde é fazer o bem. Entretanto, o que a fala a seguir revela é a falta de orientação, por parte dos profissionais de saúde, percebida pelo usuário: 
Eles (profissionais de saúde) sabendo de tudo tinha que orientar os pacientes, que isso é uma falha grande de não orientar o paciente. Que o paciente vai lá para ser orientado e ele não dá orientação, como é que fica? (E10)

Para que as ações de saúde tenham o sentido transformador que o modelo de saúde vigente requer, elas precisam estar respaldadas no fato de que as informações sobre os direitos legais de cidadãos devem ser fornecidas por uma equipe multiprofissional de saúde capacitada e competente.

Para isso, um dos eixos que o "Programa Mais Saúde: Direito de Todos" aponta como indispensável para a evolução do SUS, diz respeito à força de trabalho em saúde e tem como diretriz a ampliação e a qualificação do trabalho em saúde (BRASIL, 2008).

Nesse sentido, "uma medicina humana baseada nas necessidades do paciente faz a divulgação de informações e da educação do paciente uma obrigação profissional importante" (DRANE; PESSINI, 2005, p.62).

No entanto, apesar de todos os esforços no sentido de que haja uma capacitação profissional, a fala a seguir pode ser representativa no sentido de que os usuários parecem sentir falta de orientações básicas, como, por exemplo, "aprender a aplicar uma injeção". Vale a pena destacar que, o usuário entrevistado em questão, faz uso de insulina subcutânea e foi orientado sobre como realizar as aplicações por um amigo.

Acho que (os profissionais de saúde) deveria informar melhor os pacientes. Dizer das políticas de saúde. Dizer dos direitos. Mas se eles não falam nem como aplica uma injeção, se acha que eles vão falar outra coisa? (E9) 
Para Veloso e Ferreira (2007), a Enfermagem pode ajudar o sujeito "a tomar decisões, a ser ativo, a ter uma ação mais participativa", favorecendo a formação de sujeitos conscientes de seus direitos e deveres e capazes de transformar suas realidades.

O Código de Ética em Enfermagem, em seu Art. 41 afirma que, é responsabilidade e dever do profissional de Enfermagem, prestar informações completas e fidedignas necessárias para assegurar a continuidade da assistência. Assim sendo, é função do profissional de Enfermagem informar os usuários dos serviços de saúde (Conselho Regional de Enfermagem (COREN) - SP, 2007).

Além disso, Lunardi e Soares (2002) afirmam que a Enfermagem deve alcançar os objetivos à que se propõe ao promover assistência ao usuário como pessoa. Isso significa ter atitudes e ações de respeito, de diálogo, e reconhecer o usuário como capaz de pensar e de ter direito a ser esclarecido acerca dos seus direitos.

Isso nos atenta para a necessidade de repensar o quanto a atuação profissional tem refletido falta de compromisso com os usuários do SUS, demonstrando, sobretudo, o quanto esses profissionais não estão conscientes de seus papéis no modelo vigente, agindo de modo divergente do proposto pelo sistema (ERDMANN et al., 2008).

Em um estudo realizado com 73 enfermeiras, em dois hospitais brasileiros, com objetivo de conhecer a percepção delas acerca de suas atuações frente aos direitos dos clientes, os resultados apontaram que os direitos dos usuários mais respeitados pelas enfermeiras investigadas dizem respeito à preservação da individualidade desse cliente, seguidos pelos direitos relativos ao respeito da autonomia do cliente, à identificação pessoal e, por último, o respeito ao direito dos clientes referentes à informação para a tomada de decisão (ALVES et al, 2008).

Nesse sentido, "ignorar as necessidades de informação de um paciente é uma forma de crueldade" (DRANE; PESSINI, 2005, p.63) e contraria o principio bioético da Não - maleficência. Esse princípio consiste na obrigação de não causar prejuízos ou danos às pessoas (SELLI, 2003). Não informar os usuários sobre seus direitos nega, sobretudo, tal princípio. 
Nos EUA, as ocorrências éticas nos serviços de atenção básica foram achados importantes do estudo realizado com diversos profissionais de saúde. Dentre essas ocorrências têm-se a falta de preparo e atualização dos profissionais de saúde; o trato desrespeitoso e o fornecimento de informações inadequadas aos usuários (ROBILLARD et al, 1989).

Assim, dentre os papéis globais atribuídos à Enfermagem devemos corresponder com excelência à confiança depositada em nós, enquanto profissionais de saúde responsáveis pelo cuidado à saúde desses usuários. Para Nunes (2006), a confiança que nós temos nos outros pode ser assegurada pela responsabilidade que eles, os outros, têm para conosco. A fala a seguir, no entanto, revela a perda da confiança do usuário nos profissionais de saúde:

A gente pensa que pode confiar neles (profissionais de saúde), mas de repente quando a gente fica sabendo que eles sabendo de alguma coisa não disseram nada a gente, essa confiança cai por água abaixo... (E6)

De acordo com os resultados do European Trusted Brands de 2002, no qual se pesquisou sobre o grau de confiança nas profissões e nas políticas dos governos, em Portugal, as profissões que os sujeitos pesquisados declararam depositar muita ou bastante confiança são em ordem decrescente: pilotos de aviação (86\%), farmacêuticos (85\%), enfermeiros (82\%), médicos (78\%), sendo que os restantes aparecem com menos de 50\%. Importante enfatizar que os profissionais de saúde classificaram-se dentre os grupos que em que os cidadãos depositam maior confiança, o que implica em grande responsabilidade (NUNES, 2006).

Além da responsabilidade do profissional de Enfermagem, prevista no Código de Ética, de informar os usuários, é também lhe atribuída a responsabilidade de "encaminhar a pessoa, família e coletividade aos serviços de defesa do cidadão, nos termos da lei", conforme disposto no Art. 23 (COREN-SP, 2007). Como podemos ver na fala abaixo: 
Tinha que ter assim um lugar pras pessoas reclamar, né? Porque não tem. Pelo menos eu não sei se tem algum lugar que a gente possa ta reclamando. Eu acredito que muitas pessoas acabam até ficando sem tomar o remédio porque não tem o dinheiro pra comprar e não sabe onde reclamar. Muita gente não tem o conhecimento da onde reclamar as coisas, como eu não tenho! (E10)

Face à insatisfação, o usuário teria direito a reclamar, fato que pouco se evidencia na prática, justamente porque as pessoas desconhecem a quem recorrer com as reclamações. Em uma reflexão sobre quem seriam os chamados "advogados do usuário", Nunes (2006, p.211) conclui que "não há um grupo profissional com o monopólio ou a exclusividade da advocacia do doente e que todos os profissionais têm o dever de cuidar dos que se entregam aos seus cuidados e confiam neles".

Assim sendo, em relação aos papéis dos profissionais da saúde em informar e orientar, as falas abaixo mostram a percepção dos usuários entrevistados da forma como essa informação é fornecida, principalmente, quando há falta de medicamentos ou insumos.

Ah eles dizem que não chegou, que não fez a concorrência, que não tem, é um descaso total. (E2)

Eles (profissionais das unidades de saúde) tratam os pacientes assim: é sim, não, e vai procurar em outro lugar, "É olha aqui não tem". Eles não explicam as coisas direito, com paciência. (E9)

A educação em diabetes para a obtenção do bom controle metabólico comporta a freqüência apropriada de automonitorização da glicose sangüínea, a terapia nutricional, a atividade física regular, os esquemas terapêuticos 
farmacológicos, as instruções sobre a prevenção e tratamento das complicações crônicas e agudas, a educação contínua e o reforço e avaliação periódica dos objetivos do tratamento (ADA, 2004b; BROWN, 1999; NORRIS; ENGELGAU; NARANYAN, 2001; NORRIS et al, 2002; NORRIS, 2003; DEAKIN et al, 2005).

Diante do exposto, fica evidente o papel da equipe de saúde em informar e orientar esses usuários sobre sua doença e também sobre os seus direitos enquanto cidadão, com o intuito de alcançar verdadeiramente a humanização em saúde. Os serviços de saúde no Brasil precisam ir além de prevenir, curar e reabilitar: devem contribuir para o aumento da capacidade reflexiva e de intervenção de diferentes sujeitos sobre o social, conscientes de seus direitos e do "direito de ter direitos" (CARVALHO, 2004). Por fim, os serviços de saúde podem contribuir para a formação de cidadãos, que participem no processo de busca de informações de sua saúde como um direito.

\subsubsection{A participação ou isenção dos usuários na busca por informações}

A participação dos usuários nos serviços de saúde consiste na busca de informações, fato esse que, proporciona a ampliação dos conhecimentos sobre os aspectos relacionados à saúde, como um direito, e resulta na efetivação da saúde como direito de todos (VÁSQUEZ et al, 2003). Assim sendo, o usuário a seguir discorre sobre a importância de se buscar informações sobre o que lhe diz respeito:

Eles (usuários dos serviços de saúde) tem que se informar mais, melhor, perguntar as coisas pras pessoas quem sabem... (E3)

Em estudo realizado em dois municípios do Nordeste do Brasil, tendo como população usuários do SUS e líderes comunitários, com o objetivo de analisar os conceitos de participação social nos serviços de saúde e como estas concepções poderiam influenciar na implementação da política de participação em saúde, pode- 
se perceber que, em ambos os municípios, as pessoas entrevistadas tiveram dificuldades para definir esses conceitos (VÁSQUEZ et al, 2003).

Assim, tem-se a responsabilidade desses usuários na aquisição de conhecimentos e na busca por informações relativas à sua saúde e aos seus direitos. Destaca-se o papel do usuário como ser ativo e não apenas receptor de informações. Para o entrevistado a seguir, parece existir uma "falta de interesse" na busca de informações, por parte dos usuários da saúde:

Falta de interesse. Porque não tá precisando, porque quando você tá precisando você vai atrás dos seus interesses. Você pode perguntar pra um ex-presidiário, ele sabe tudo da lei, do crime que ele cometeu. Ele sabe tudinho de cor e salteado. E também porque tem muita gente que é acomodado. Se meu irmão, por exemplo tiver diabetes ele não vai atrás de nada, ele é muito tranqüilo. (E9)

A informação segundo Nunes, Dupas e Ferreira (2007) é primordial para usuários com diabetes. Entretanto, faz-se necessário dizer que, o manuseio da informação torna-se importante quando "potencializa o triângulo terapêutico: equipe multidisciplinar, família e equipamentos sociais" (ZANETTI et al., 2008).

No entanto, como já visto a capacidade de gozo de direitos nem sempre resulta na capacidade de agir para exercer direitos (MARCHI, 1998). Assim, as pessoas nem sempre estão empoderadas para exercerem seus direitos e nem sempre conseguem "erguer sua voz para sugerir modificações ou reclamar" (NUNES, 2006). A esse exemplo, temos a fala a seguir:

Olha pra ser bem sincera eu não sei como lutar. Eu não sei como fazer isso, você entendeu? Eu não sei como porque já diz o ditado: "A corda arrebenta pelo lado do mais fraco". Então é difícil. (E7) 
Importante salientar que, a fala acima denota uma relação de dependência e a percepção de impotência do usuário frente às adversidades impostas pelas conformações do sistema de saúde. Além disso, confere a esse usuário um perfil de categoria social destituída de poder que não consegue se organizar e vocalizar as suas demandas (VAITSMAN; ANDRADE, 2005).

Por dependência entende-se o estado em que a pessoa é incapaz de existir de maneira satisfatória sem a ajuda de outras pessoas, podendo ter seu poder de autonomia reduzido ou anulado (BALTES; SILVERBERG, 1995; COSTA; LUNARDI; LUNARDI FILHO, 2007).

Aqui faz-se necessário dizer que, por meio do Decreto 4.726, 09 de junho de 2003, foi criada a Ouvidoria Geral do SUS, a qual tem por finalidade servir como um canal de articulação entre o usuário de saúde e a gestão pública de saúde. Dentre suas atribuições, encontra-se o recebimento de solicitações, denúncias, reclamações, elogios e sugestões. Além disso, compete à Ouvidoria também assegurar aos cidadãos o acesso às informações sobre o direito à saúde e informações sobre como exercer esse direito (BRASIL, 2003a; BRASIL, 2007a).

Além disso, a participação contínua da sociedade na gestão pública é um direito assegurado pela Constituição Federal e permite que os cidadãos participem da formulação de políticas públicas e fiscalizem de forma permanente a aplicação dos recursos. Para tanto, os Conselhos de Saúde, órgãos permanentes e deliberativos reúnem representantes do Governo, dos profissionais de saúde e dos usuários do SUS (BRASIL, 1990b; BRASIL, 2008).

É possível notar que o usuário entrevistado revela através de sua fala que além do constitucionalmente verificado são necessárias outras atribuições para que os usuários possam exercer seus direitos:

Perante a lei, todo mundo é cidadão, mas na realidade as coisas não funcionam dessa forma, se você precisa de uma determinada coisa, se você não tiver um determinado estudo, conhecimento você não consegue. Isso a lei, a constituição diz que os direitos são iguais pra todos, mas não é o que você vê na verdade. Porque as pessoas que 
tem mais conhecimento sabem melhor fazer valer os seus direitos. Até para saber dialogar é diferente. (E4)

Importante ressaltar que a justiça, aqui entendida, enquanto princípio bioético, está estreitamente interligada à equidade. Assim, a justiça estabelece padrões de distribuição de bens e a equidade é um desses padrões. Ao entender o conhecimento como um bem indispensável à legitimação dos direitos, de acordo com a fala acima, pode-se inferir que esse bem talvez não esteja sendo distribuído de maneira equânime e, portanto justa nos serviços de saúde para os usuários com diabetes (DRANE, PESSINI, 2005).

Sem a necessária e suficiente informação torna-se quase impossível para qualquer pessoa ser "capaz de reivindicar e/ou lutar pelos seus direitos, não tendo condições e nem argumentos para questionar, dificultando, dessa forma, o exercício de sua autonomia" (CHAVES; COSTA; LUNARDI, 2007, p.55). Nesse sentido, o usuário abaixo revela suas limitações em reivindicar seus direitos, sem a orientação de outras pessoas:

Eu? RISOS... Ah eu sou muito lenta pra essas coisas... Acho que alguém teria que me orientar...RISOS...Não sei não o que eu poderia fazer, como poderia participar... (E1)

Desta forma, se configuram as dificuldades dos usuários em vislumbrar possibilidades de participação na construção da cidadania e do controle social nas políticas públicas de saúde do Brasil. Aqui uma ressalva para o fato de que, o controle social deve ser entendido como uma parte da participação social cidadã. Esse controle, se encontra articulado, integralmente, à atuação da política pública, no sentido de controlar o desenvolvimento das políticas que são definidas para atender às necessidades dos usuários dos serviços de saúde (TOVAR, 2007).

Se por um lado, ainda há incapacidade de alguns usuários em exercerem seus direitos, por outro alguns usuários dispõem de mecanismos informais que 
podem resultar no exercício do direito. Embora, muitas vezes, eles tenham que abrir mão da cordialidade e reclamar para que sejam reconhecidos como pessoas autônomas e portadoras de direitos. A fala a seguir, é ilustrativa nesse sentido:

Eu falo, um dia eu falei lá pra moça, você quer ser bem atendida? Chuta o balcão aqui, fui até grosso, cospe na cara da menina, apesar dela não ter nada a ver com isso, mas pelo menos vai chamar a atenção, aí vão arrumar remédio pra você. (E2)

O mesmo entrevistado faz referência ao fato de que as pessoas que não possuem escolaridade sofrem mais no atendimento. Nesse sentido temos, com alguns estudos que a baixa escolaridade pode dificultar o acesso às informações e, consequentemente, reduzir a capacidade dos usuários para exercer seus direitos (ALVES, 2005; PAIVA, BERSUSA, ESCUDER, 2006; DELAMATER, 2006). Em nosso estudo, houve o predomínio de $8(66,6 \%)$ usuários com segundo grau completo. Assim, temos a fala a seguir:

E ainda que eu tenho curso superior eu chego lá e falo, falo alto e falo bravo! Então eu consigo ser atendido, agora calcula esse povo que não tem escolaridade nenhuma, o que isso sofre, minha filha, é brincadeira! Dá dó, é penalizador! (E2)

Com o objetivo final de ser respeitado em seus direitos, alguns usuários buscam soluções que envolvem autoridades de Municípios, como apreende-se nas falas que se seguem:

Fazer uma reclamação pra quem é de direito, por exemplo, numa cidade pequena como a que eu moro, vai falar lá no gabinete do 
prefeito, lá com a parte social, assistente social, tem que meter a boca, né? Eu acho assim, se é direito do cidadão, então vai reclamar. (E4)

Eu acho que ai deveria primeiramente convocar uma reunião com a enfermeira que é a chefe para ver o que é que está acontecendo, se ela não resolver, você tem que ir atrás do prefeito da cidade, por exemplo, para ver como pode ser feito, secretário da promoção social, que atua também nessa área, que ele ajuda, eu acho que seria por ai. (E7)

Assim, é necessário que haja uma co-participação entre poder público, profissionais de saúde e usuários dos serviços de saúde para que o pleno exercício dos direitos dos usuários seja reconhecido. O Poder público deve prover recursos, informar os usuários e favorecer o processo de formação de profissionais competentes para o cuidado humanizado.

Para tanto, a humanização, como prática adotada nos serviços de saúde deve configurar um ambiente, no qual os princípios éticos e morais permeiem as interações entre profissionais - usuários, com o intuito de positivar tais relações.

\subsection{A qualidade da interação profissional-usuário nos serviços de saúde}

Neste tema foi possível mostrar, de acordo com as falas dos entrevistados, que os usuários com diabetes parecem descontentes com a maneira que o atendimento em saúde tem sido oferecido. Por outro lado, os entrevistados aparentam discernimento para vislumbrar quais seriam as mudanças necessárias para que se alcance efetivamente melhor qualidade da interação profissional de saúde-usuário. Assim, as categorias que emergiram foram: A (des)humanização do atendimento nos serviços de saúde e a percepção da necessidade de transformação da prática assistencial. 


\subsubsection{A (des)humanização do atendimento nos serviços de saúde}

O princípio da não maleficência afirma a obrigação de não causar danos aos outros. Deste modo, por cuidado humanizado compreende-se cuidar de maneira suficientemente acolhedora e apropriada para evitar causar danos físicos, psíquicos ou sociais. Para tanto, é necessário que os profissionais sejam prudentes, sensatos e justos em suas ações, com o intuito de atender as necessidades dos usuários dos serviços de saúde. A má prática profissional constitui em um exemplo de negligência que pode ser causada pela inobservância dos padrões éticos inerentes à prática do cuidado (BEAUCHAMP; CHILDRESS, 1979).

Nas entrevistas realizadas, a fala abaixo mostra que as necessidades do participante parece não ser reconhecida pelos profissionais de saúde, o que interfere na relação de escuta e responsabilização, as quais se articulam com a construção de vínculo:

Muitas vezes eles te tratam com descaso, com pressa. Tem certas coisas que eu não tolero, eu fui renovar minha carta, tem que pagar antes e aquela coisa toda, né? E eu não entro se você não me disser que eu posso entrar, eu sou um cara educado! Mas não passa o meu direito não, que aí as coisas mudam. Aí eu fui lá, ele mandou sentar, sentei, mas ele nem me cumprimentou, nem me olhou na cara. E acho isso uma falta de respeito, porque a pessoa... SILÊNCIO... Porque a pessoa mais importante pra mim agora é você que tá na minha frente. Tá certo? Aí ele mandou eu ficar em pé, "fica em pé aí, com a mão direita, levanta a perna da calça da perna direita”, eu levantei. Agora ao contrário, a mão esquerda. Eu fiquei curioso, porque eu nunca ouvi falar desse exame. Falei: "Doutor que exame o Senhor tá fazendo?" "Pra ver se você não tem perna de pau!" Ahhh, aquilo bateu lá na minha alma, eu falei: "O Senhor não foi na escola de português o dia em que ensinaram, tem uma coisinha que chama semântica, o Senhor não aprendeu isso! E o dia que deram na medicina que ensinaram pro 
Senhor o que que é prótese, o Senhor também não foi! Acabou nosso negócio, assina minha carta que eu tô indo embora. E não fala mais nada pra mim não ficar mais nervoso do que eu tô! Ele assinou a carta e eu fui embora. Tem cabimento ouvir isso de um... SILÊNCIO... Isso é um Zé das Abobra.(E2)

Estudos têm demonstrado precária interação entre usuários de saúde e profissionais de saúde; despreparo dos profissionais para lidar com as dimensões subjetivas dos usuários em suas práticas cotidianas e do desrespeito freqüente aos direitos dos usuários (REIS; MARAZINA; GALLO, 2004; PINHO; SIQUEIRA; PINHO, 2006). Surge então, a necessidade de se pensar em uma Política Nacional de Humanização (BRASIL, 2004b).

O núcleo do conceito de humanização é a idéia de dignidade e respeito à vida humana, que se enfatiza na dimensão ética entre usuários e profissionais de saúde (VAITSMAN; ANDRADE, 2005). Logo, por humanização entende-se a valorização dos diferentes sujeitos implicados no processo de produção de saúde: usuários, trabalhadores e gestores. Os valores que norteiam esta política são a autonomia e o protagonismo dos sujeitos, a co-responsabilidade entre eles, o estabelecimento de vínculos solidários e a participação coletiva no processo de gestão (BRASIL, 2004b).

De acordo com Nunes (2006, p. 208), "cartas e declarações de direitos, assim como manuais de boas práticas, servem para guiar a ação no sentido da humanização dos serviços de saúde", no entanto, seria incorreto dizer que declarações de direitos funcionam como instrumentos de ação imediata e eficaz na mudança de uma realidade.

Logo, é necessário que esse norteamento para "as boas práticas" sejam incorporadas no dia-a-dia dos profissionais de saúde, para que haja satisfação por parte dos usuários de saúde em receber o que lhe é de direito. Para tanto, temos que "a satisfação dos usuários consiste no modo como eles se apercebem dos serviços prestados, dependendo de fatores como expectativas conscientes e as suposições inconscientes, bem como a experiência prévia com o serviço" (NUNES, 2006, p. 210). 
Nesse sentido, o entrevistado a seguir, relata que diante da sua experiência ruim com o profissional de saúde, não retornou mais ao Serviço, e dessa forma pode ter comprometido a continuidade do seu tratamento:

Ela (médica) falou que eu já estava com quase $100 \mathrm{Kg}$. Médica: "Você tá com quase $100 \mathrm{Kg}$, e você pode se considerar uma diabética. Que já deu $126 \mathrm{mg} / \mathrm{dL}$ no seu exame e você tá tudo alterado! Tá colesterol, tá num sei o que, num sei que lá”. Falou um monte de coisa pra mim, que eu não tive nem palavra pra perguntar alguma coisa pra ela, o que que eu deveria fazer, porque eu me senti muito humilhada. Eu me senti humilhada, aí então eu não fiz pergunta e não voltei mais. (E10)

Para Merhy (1992), ao se adotar práticas centradas no usuário, faz-se necessário desenvolver capacidades de acolher, responsabilizar, resolver e autonomizar. Nesse sentido, o trabalho em saúde deve incorporar mais tecnologias leves que se materializam em práticas relacionais, como, por exemplo, acolhimento e vínculo (SOUZA et al. 2008).

O acolhimento, aqui entendido como a recepção do usuário, desde sua chegada, responsabilizando-se integralmente por ele, ouvindo sua queixa, permite que ele expresse suas preocupações, angústias (BRASIL, 2004b). Segundo Gastal e Gutfreind (2007) as representações sociais dos profissionais e da estrutura do sistema de saúde surgem como desprovidos de compreensão, respeito e acolhimento, exemplificado na fala abaixo. O profissional, ao não acolher a pessoa, a estaria privando da satisfação de um direito: o de que o sistema de saúde cumpra funções de apoio social:

Porque eu vou na médica, aí ela fala você precisa emagrecer, dá um papelzinho que é um papelzinho falando que você pode comer um pires disso, um pires daquilo, uma xícaras disso, uma xícaras daquilo. Isso eu sei! (irritação). Isso eu sei poxa! Mas ela não conversa com 
você. É assim: pesou? Sua pressão tá boa? Ah então tá bom. Quanto você toma de insulina mesmo? A pessoa não tem nem a capacidade de ver na pasta quanto eu tomo de insulina. Nem pega na mão, entendeu? É muito rápido. Pode um profissional desse? Poxa eu sou ser humano, digno de respeito, não sou? Se eu vou fazer uma festa pra você e chegar e começar a jogar comida no balcão pra você comer. Você vai dizer, aqui ninguém é porco! Entendeu? Então é mais ou menos isso! A primeira vez que eu fui nela, ela disse: o que que o Senhor deseja? Uai, se eu tô aqui é porque eu preciso de alguma coisa. Ela fez o seguinte: escreveu lá, tira sangue, urina...Eu falei a Senhora não vai me dar a receita de insulina? Ela fez: Você usa insulina?/ Uso. Ah tá, assinou, deu e pronto até logo. Sabe coisa rápida! Só sei que tá uma $m$...! Eles nem te olham na cara! É ser humano que eles tão lidando, a gente não se sente nem um pouco acolhido. (E9)

Dentre as definições para dignidade proposta pela Organização Mundial da Saúde (2000a) temos que dignidade é ser tratado com respeito e consideração em qualquer circunstância, além de ser recebido nas unidades de saúde de maneira atenciosa. Sendo o respeito à pessoa humana um dos valores básicos da sociedade moderna, cada pessoa deve ser vista como um fim em si mesma e não como um meio (FORTES, 2005).

Diante do exposto, o acolhimento deve ser visto como um dispositivo potente para atender a exigência de acesso e, propiciar vínculo entre a equipe e a população, entre o trabalhador e o usuário. Além disso, pode servir como disparador no sentido de promover questionamentos acerca do processo de trabalho, com o objetivo de refletir e praticar o respeito à dignidade humana, desencadeando, por fim, a autonomia dos usuários e o cuidado integral e humanizado (SOUZA et al., 2008).

Tendo em vista o conceito de acesso com uma das ferramentas para o acolhimento, foi possível observar em nosso estudo que, na percepção dos usuários ainda há dificuldades para que esse seja concretizado na prática. Assim, Starfield 
(2004) discute acesso e acessibilidade e demonstra que, embora os dois termos pareçam ambíguos, eles possuem significados complementares. Dessa maneira, "a acessibilidade possibilita que as pessoas cheguem aos serviços, e o acesso permite o uso oportuno dos serviços para alcançar os melhores resultados possíveis" (SOUZA et al., 2008).

O acesso ao agendamento de consultas foi a principal dificuldade encontrada pelos usuários para a realização do seguimento do DM de maneira adequada:

... desde que eu tive hipoglicemia que eu fui internada, eu ainda não consegui marcar uma consulta, não consegue... eu vou lá a moça fala : “ahh não abriu a pasta ainda, ahh não sei o quê...” fica dando desculpa e eu não consigo marcar a consulta...eu acho que eu tenho direito sim de ter a consulta e de ganhar os remédios sim...eu tenho direito dos remédios...não é?? Eu acho que sim... (E1)

A dificuldade maior é marcar as consultas. (E9)

Esse problema burocrático interno das unidades de saúde pode comprometer a recomendação de que a avaliação do usuário com diabetes deve ser realizada, por meio de consulta médica e de enfermagem, a cada três ou quatro meses para aqueles que estão estáveis e com o controle satisfatório e, em menor espaço de tempo para os usuários com controle instável (RIBEIRÃO PRETO, 2006; SBD, 2007).

Dessa forma, com o intuito de alcançar o controle metabólico, na prática, os usuários ainda parecem enfrentar obstáculos para o alcance das recomendações de atendimento preconizadas. Segundo Berlinguer (2004), essas dificuldades configuram uma questão denominada como problemas da bioética cotidiana, uma vez que ocorrem reiteradamente no cotidiano desses usuários. 
Ademais, um dos intuitos da implementação da Política Nacional de Humanização (2004b) é reduzir as filas e o tempo de espera. Entretanto, os entrevistados parecem ainda insatisfeitos com o tempo que eles aguardam para marcar suas consultas e relatam certa inconformidade diante de tal situação:

Toda vez que você vai lá, nunca pode agendar... tem que voltar...dessa vez eu acho que eu já fui umas três vezes...e eu não consigo agendar...não consigo... Imagina uma pessoa diabética ficar seis meses sem consulta...eu não conformo... (E4)

... você tem que esperar abrir a agenda, por exemplo, quando eu entrei aqui eu tinha consultado, foi no dia 4 que eu consultei, aí eu tenho que esperar abrir a agenda, daí três meses pra consultar de novo, aí é que pede os exames pra gente fazer novamente, mas agora como é final de ano, ninguém ta agendando nada. Sabe? (E12)

Diante do exposto, o usuário a seguir faz uma sugestão no sentido de contribuir para o atraso do profissional para as consultas nos serviços. Ele propõe de maneira aparentemente tímida que, os profissionais de saúde deveriam compensar os atrasos do dia anterior:

Eu acho que no posto deveria, por exemplo, fazer uns encaixes, por exemplo, se ela não veio um dia que atrasou, no outro dia, ela (médica) trabalhar para por um pouco mais para agilizar aqueles pacientes que ficaram para trás. (E7).

O principio da Justiça aparece na fala do entrevistado a seguir, na medida em que ele faz o contraponto entre a demora para o atendimento no posto de saúde e a 
grande demanda dos serviços de saúde, revelando a importância de todos serem atendidos:

No posto, normalmente você demora um pouco mais para ser atendido por causa que é pouco profissional às vezes para acompanhar, então a demanda é muito grande, então a gente tem que entender porque todo mundo tem direito a ser atendido. (E7)

Segundo Dinsdale et al., (2000) no setor público, o usuário pode se colocar ora como consumidor, avaliando os serviços do ponto de vista de seus ganhos individuais, ora como cidadão, avaliando os serviços ao levar em conta a sociedade como um todo. Como consumidor, ele pode desejar um tempo de espera menor para a consulta e atendimento mais ágil, mas, como cidadão, pode querer que todas as pessoas sejam atendidas, implicando um tempo de espera maior.

Foi possível notar também que, apesar dos esforços observados com o objetivo de implementar a Política Nacional de Humanização (BRASIL, 2004b) alguns entrevistados ainda, se mostram descontentes com a impessoalidade da relação entre profissionais de saúde-usuários, nos postos de saúde, como podemos ver na fala que se segue:

Profissional de posto é péssimo, é bem grosseiro, né? Não são bons não... Apesar que, eu sou uma pessoa assim, muito na minha, sabe? Eu entro eu falo bom dia, boa tarde, eu sou de tratar bem, se não me fala nada, eu também não falo nada... (E6)

O atendimento é só isso que eu te falei, só pergunta, não te examina, viu? Não examina, médico do postinho, a maioria ele não te põe a mão não, ele fica de lá, você fica de cá, ele faz algumas perguntas e só isso. (E1) 
Chama a atenção um estudo etnográfico realizado em Manaus, Amazonas, com o intuito de analisar os resultados de uma pesquisa avaliativa de Atenção Básica à Saúde com os usuários com hipertensão arterial e/ou diabetes mellitus. Os autores evidenciaram que o cuidado oferecido se restringe às queixas físicas passíveis de abordagem farmacológica, comprometendo dessa maneira a integralidade em saúde (SOUZA; GARNELO, 2008). Tal fato, também pôde ser percebido pelos usuários entrevistados em nosso estudo, conforme a fala a seguir:

No posto eles são mais secos, né? Só perguntam: oi tudo bom e o que você tá sentindo, examina ali e tal, já receita o remédio e pronto. (E4)

Além disso, no estudo de Souza e Garnelo (2008), observou-se que na percepção dos usuários há deficiência na capacidade de escuta dos profissionais de saúde em relação às necessidades dos usuários, conforme podemos perceber também nas falas que se seguem:

No posto é uma grosseria a gente não tem como... Eu vou te falar, a maioria das vezes a gente não é muito bem tratado não, às vezes trata assim com indiferença, sabe, para conversar é muito pouco que conversa. Às vezes as pessoas não entende o que eles (profissionais de saúde) está falando e eles (profissionais de saúde) não torna a explicar, não torna a falar. A maioria (dos usuários) pega a explicação, outros não. (E10)

Que tem muito médico que termina de chegar lá, atende já te dispensa, não tem diálogo, principalmente os médicos mais antigos. Ele chega lá e acha que é dono de todas coisas, ele não tem um dialogo com você, só fala o que você está sentindo aí? Estou passando isso aqui e está dispensado, tchau. Ele nem explica nada... é tchau e pronto. (E7) 
O profissional de saúde deve ouvir a pessoa cuidadosamente e fornecer explicações de modo que o usuário possa entender, dispondo de tempo suficiente para esclarecer todas as suas dúvidas (OMS, 2000b). Dessa maneira, é preciso qualificar os profissionais de saúde para recepcionar, atender, escutar, dialogar, tomar decisão, amparar, orientar e negociar com os usuários (FAGUNDES, 2004).

$\mathrm{Na}$ fala abaixo demonstramos a percepção do usuário de que os profissionais de saúde possuem como obrigação ética fundamental agir para o bem-estar dos usuários, o que constitui no âmbito da Bioética no princípio da beneficência (FORTES, 2001).

Sei lá, acho que tinha que ter mais médicos, um médico mais atencioso, com mais interesse, sabe? Com mais amor... porque os médicos...não...SILÊNCIO...não tem amor no paciente...no próximo, né? Então eles tratam o paciente de qualquer jeito... não como deveria ser... (E1)

Outro dia eu fui no posto e ele (médico) tava lá sentado. Eu falei: eu posso falar com o Senhor? Ele falou: tem hora marcada? Eu disse: não. Ele disse: então não dá. (E9)

Assim, a receptividade dos profissionais de saúde para com os usuários é outro fator indispensável para a formação de vínculo e satisfação do usuário. Dentre as metodologias utilizadas para pesquisa de satisfação de usuários, temos que a proposta por Parasuraman et al (1988) destaca a importância da receptividade, que o autor define como sendo a "prontidão em ajudar e responder às necessidades dos usuários".

Dessa forma, os princípios de beneficência e não- maleficência destinam-se a melhorar o bem-estar das pessoas com que se trabalham (BEAUCHAMP; CHILDRESS, 1979). Segundo Fortes (2005, p. 16), o progressivo afastamento do profissional de saúde de seus usuários, torna a relação entre eles cada vez mais 
distante, impessoal e despersonalizada, fato esse que converge com a percepção do entrevistado a seguir:

É bem assim... não te olhando na cara entendeu? Pega a receita ali, olha, põe lá e não fala nada... não orienta nada...é bem impessoal o tratamento... (E3)

Se eu vou medir a pressão eu boto o braço lá, se não fala nada (profissional da enfermagem) eu também não falo nada... mas é tudo assim no posto, mas eu fico na minha... Eu acho que é um atendimento muito impessoal... teria que melhorar muito, né??? Eles (profissionais da saúde) não estão nem aí com a paçoca.(E6)

Você vai lá elas perguntam o que que é, eu falo:"eu vim tirar minha glicemia”, aí ela vê, mas não fala nada. Só verifica e dá o resultado ali, só isso que elas fazem, mais nada. (E4)

A implementação da Política Nacional de Humanização (2004b) também se justifica devido ao quadro de desvalorização dos trabalhadores de saúde, expressiva precarização das relações de trabalho, baixo investimento num processo de educação permanente desses trabalhadores, pouca participação na gestão dos serviços e frágil vínculo com os usuários, como pôde ser retratado na percepção do usuário a seguir:

O próprio médico não orienta nada, ele tá lá só pra pegar o dinheiro, e ainda tá nervoso porque acham que o salário é pequeno, mas eles têm que ficar lá quatro horas, pra depois pegar o dinheiro e ir embora. Eles nem olham na cara do paciente. Eles são mercenários! Ele não vai por causa do ser humano, ele vai por causa do dinheiro. (E2) 
A esse respeito temos com Fortes (2005, p. 12) que:

\begin{abstract}
Entre os trabalhadores de saúde, componente essencial do sistema de saúde, encontramos, tanto no setor público quanto no privado, inúmeros profissionais em difícil situação para o exercício correto de suas profissões. Desmotivados, trabalhando em dois ou mais empregos, condição que resulta na falta de vínculo adequado com os serviços e a clientela, condição facilitadora da desumanização da assistência à saúde.
\end{abstract}

Diante disso, é de suma importância que as práticas de saúde sejam repensadas bem como a maneira como essas estão sendo desempenhadas, com o intuito de que as ações em saúde reflitam uma assistência humanizada em consonância com o que de fato o direito à saúde se propõe a oferecer.

Assim como a assistência humanizada é o pilar para essa transformação, tem-se com a ADA (2009), que a educação para o auto-cuidado é a pedra angular do tratamento para todas as pessoas com diabetes. Para tanto, a educação em diabetes deve ser desenvolvida por profissionais capacitados, que trabalhem com a possibilidade de desenvolver políticas, procedimentos e protocolos para garantir que sejam reconhecidos nacionalmente a educação e que as orientações sejam aplicadas nas ações diárias.

\title{
5.4.2 A percepção da necessidade de transformação da prática assistencial
}

O estudo foi realizado em um Centro que tem por objetivo promover a educação do usuário com diabetes, instrumentalizando com conceitos essenciais para o entendimento do diabetes mellitus, suas implicações e os recursos necessários para o alcance do bom controle metabólico, conforme recomendações de sociedades, associações e do Ministério da saúde para o atendimento em diabetes (SBD, 2007; ADA, 2005; BRASIL, 2001b; BRASIL, 2002a; BRASIL, 2002b; BRASIL, 2006b; OMS, 2003; OPAS, 2004; ADA, 2009). 
Nesse contexto, a formação de vínculo, a empatia e a disponibilidade para escuta parecem ser cruciais na adesão desses usuários ao grupo. Tal fato, pôde ser evidenciado na fala que se segue e nos remete à necessidade de repensarmos nossa prática assistencial na direção de questionar como estamos desempenhando nossos papéis de profissionais de saúde e de que maneira nossas ações estão sendo interpretadas pelos usuários:

Logo no início que a gente sabe que tem diabetes, a gente não é bem orientado. A gente vai no posto e aí eles dizem: "olha o Sr tem diabetes, o Senhor precisa controlar, fazer exercício". Mas não explica como a gente deve comer, o que a gente deve fazer, né? Porque igual eu, eu tratava do diabetes com comprimido, mas eu comia errado, então eu acho que falta um pouco de educação, orientação. E foi o que eu encontrei aqui, depois de tanto tempo, vocês me ajudaram muito. Vocês escutam as nossas ansiedades e orientam. Vocês esclarecem tudo que a gente tem dúvida e estão de parabéns por isso! É isso que falta na saúde, pessoas como vocês. (E4)

De acordo com Hennington (2005), os programas de extensão universitária desvelam a importância de sua existência na relação estabelecida entre instituição e sociedade, consolidando-se através da aproximação e troca de conhecimentos e experiências entre professores, alunos e população. Na área da saúde, assumem particular importância na medida em que se integram à rede assistencial e podem servir de espaço diferenciado para novas experiências voltadas à humanização, ao cuidado e à qualificação da atenção à saúde.

Chama-nos a atenção o fato de que todos os usuários entrevistados 12 (100\%) referiram nunca ter participado de um programa de educação em diabetes, ao contrário do que está preconizado na legislação vigente em diabetes.

De acordo com Puccini e Cecílio (2004), um dos momentos que exige uma resposta rápida, sob pena de implodir o SUS e com ele o direito à saúde, é 
certamente o desencontro, o descrédito e a desconfiança dos usuários em relação aos serviços de saúde.

Assim, o bom profissional na visão dos entrevistados se define como uma pessoa atenciosa, generosa, disponível e comprometida com o bem-estar dos usuários como um todo:

É diferente você ser atendido por um bom profissional. Teve um dia $q$ eu fiquei 15 dias sem dormir, tava igual uma manga chupada. O doutor Augusto me viu na rua, parou o carro e me disse: Antônio você pode ir no posto me procurar? Eu disse: Posso doutor que horas? Qualquer horário, não precisa marcar horário. Daí eu fui lá ele falou pra secretária que já tava sabendo e pediu pra eu esperar só um pouquinho que ele terminando o paciente que ele tava atendendo ele já conversava comigo. Quando eu entrei ele falou: O que que tá havendo? Você não tá dormindo, tá trabalhando demais? Você não pode ficar sem dormir rapaz! Sabe? Então se preocupou comigo. (E9)

Na saúde deveria ter pessoas que trabalham na saúde com amor, com prazer, com respeito ao paciente. (E1)

Primeiro tem que ser pessoas atenciosas, porque quem procura saúde tá com algum problema. Uma pessoa que tá com problema é uma pessoa que não tá normal. Então esse profissional tem que ser a professora do primário, é a tia, é o tio, é o pai e é a mãe (E11).

Dessa maneira, pode se alcançar o real sentido do princípio da Beneficência, que consiste em fazer o bem. Tal princípio prevê para o profissional de saúde, o "comportamento moral de fazer o bem e promover o bem estar" (SELLI, 2003, p. 45). Nesse sentido, sendo o princípio da Beneficência um dos pilares da Bioética, há a 
necessidade de que as ações desempenhadas pelos profissionais de saúde sejam pensadas e repensadas nesse âmbito, para que comportamentos arraigados possam ser modificados tendo como orientação as atitudes responsáveis e éticas para com os usuários.

Importante salientar que, a noção de que todas as pessoas devem ser atendidas nos remete ao princípio da justiça, outro pilar da Bioética, uma vez que todos têm o direito de ser atendido em suas necessidades, enquanto cidadãos. Tal princípio trata, portanto, do plano social e político no que diz respeito à alocação suficiente de recursos para atender às necessidades da área da saúde (PEGORARO, 2006).

Dessa forma, ao se realizar a alocação de recursos para a implementação do monitoramento da glicemia capilar, ficou estabelecido que para usuários com diabetes que não faz uso de insulina a monitorização da glicemia capilar deve ser realizada na unidade de saúde mais próxima da residência do usuário (BRASIL, 2007b). Na fala a seguir, o entrevistado aponta falhas na distribuição das tiras de glicemia na Unidade de saúde:

A gente vai no posto as moças fala "Ah..." nunca tem fita, não mede. Elas sempre falam que não tem a fita. (E11)

Em contrapartida, encontramos em nosso estudo 4 (33\%) usuários com diabetes em uso de insulina, que receberam o monitor de glicemia e recebem mensalmente as fitas para a automonitorização domiciliar da glicemia capilar.

Agora o que eu tenho assim que é gratuito, seria o aparelhinho, que eu vou medir o Diabetes e as fitinhas que se recebe, que eu pego, fora essa oportunidade que vocês estão dando para gente aqui que é o....Esse...Esse acompanhamento, essa troca de idéias que eu estou gostando muito. (E10) 
Sabe-se que muitos usuários, por razões de ordem econômica, social ou psicológica apresentam dificuldades para a automonitorização. Soma-se a isso, a falta de compreensão dos profissionais de saúde, assim como dos próprios usuários, acerca da importância de realizá-la e como interpretar os resultados obtidos. (ADA, 2004b; SBD, 2006). Nessa direção, embora os usuários com diabetes que fazem uso de insulina tenham o direito a obter o glicosímetro e os insumos necessários para a automonitorização da glicemia em domicílio, em nosso estudo pudemos identificar que um usuário (E9) apesar de possuir o glicosímetro e as tiras reagentes, não realiza a monitorização da glicemia capilar:

Enche o saco furar o dedo todo dia, todo dia... Enche o saco furar o dedo poxa! É muito chato, aí eu falei: "não vou furar mais" e não furei mais. Eu furava de manhã e a tarde... Eles te dão uma ficha de manhã, à tarde e, a noite, uma hora após meio dia, meio dia, após o meio dia, às 18 horas, após a meia noite, certinho ali, em jejum, sempre marcava ali,e entregava lá para eles, aí eles me davam mais fitinhas. Quando eu falei lá pra moça (profissional da farmácia) que eu não ia fazer mais, ela falou: "eu não vou te cobrar, mas você não vai pegar lancetinhas, não vai pegar mais agulha, a partir de um momento que você começar a furar o dedo, o senhor vai ter que me entregar o relatório senão não te dou nada disso (E6).

Por falta de informações, as pessoas com diabetes freqüentemente desconhecem a importância da monitorização glicêmica e quais são as ações mais adequadas a tomar em resposta aos resultados da glicemia, obtidos através do automonitoramento da glicemia (BERGENSTAL; GAVIN, 2005). Nesse sentido, o fornecimento dos insumos parece estar ocorrendo. No entanto, as orientações relativas à importância da automonitorização e às condutas a serem assumidas diante dos resultados obtidos parecem não estar sendo realizadas na prática, pelos profissionais de saúde, conforme a fala do usuário que segue abaixo: 
Eu pego com a farmacêutica, mas não sei se ela é formada....A orientação eles já me deram no dia em que entregaram o aparelho, qualquer dúvida vocês pode nos procurar, então foi isso que eles disseram pra mim...(E10)

Assim, a monitorização da glicemia dentro da educação em diabetes representa um importante avanço no controle metabólico do diabetes mellitus, pois seus resultados são imediatos e quando correlacionados com os valores laboratoriais, permitem a compreensão da interação entre a dieta, medicação e exercícios, além de promover o senso e a responsabilidade de controle nos usuários (ADA, 2004b). Segundo Karter et al (2000), 67\% das pessoas com diabetes tipo 2 e $60 \%$ com diabetes tipo 1 , realizavam os testes de glicemia capilar com uma freqüência menor do que o recomendado pela Associação Americana de Diabetes.

Portanto, de acordo com Fortes (2005, p.18), é fundamental que haja uma reformulação das práticas cotidianas dos serviços de saúde e da cultura prevalente entre os profissionais de saúde. Para tanto, os princípios éticos devem ser adotados como variáveis de qualidade institucional e também como qualidade de ação profissional, e necessitam ser observadas na prática, na constante busca da efetivação dos direitos dos usuários com diabetes. Dessa forma, é necessário primeiramente, que as "ações e os serviços de saúde sejam orientados no sentido de humanizar suas práticas".

Ademais, de acordo com as diretrizes da SBD (2009) as evidências científicas são apenas um dos componentes na tomada de decisão, onde devem ser considerados as preferências dos usuários, que deve ser esclarecido, as circunstâncias do atendimento, o estadiamento da doença, e os recursos disponíveis. A experiência do profissional é fundamental e faz muita diferença, podendo moldar a decisão final e garantir maior benefício e autonomia ao usuário com diabetes, principalmente, em relação ao monitoramento da glicemia capilar.

Logo, fica evidente a possibilidade de agirmos como profissionais transformadores da nossa realidade. Essa transformação deve buscar, sobretudo a humanização das relações entre profissionais de saúde e usuários, como reflexo do respeito à dignidade humana e à autonomia dos sujeitos, para enfim, configurarmos um ambiente em que haja a plenitude do exercício dos direitos dos usuários com diabetes mellitus. 
6 CONSIDERAÇÕES FINAIS 
Neste estudo de abordagem qualitativa investigou-se o conhecimento dos usuários com Diabetes mellitus acerca dos seus direitos e benefícios em saúde advindos da legislação vigente. A abordagem metodológica adotada possibilitou a identificação de três temas: a não-consciência dos usuários com diabetes mellitus acerca dos seus direitos; a co-responsabilidade em saúde no que diz respeito ao fornecimento de informações e à efetivação dos direitos dos usuários com diabetes mellitus e a qualidade da interação profissional-usuário nos serviços de saúde.

O tema A não-consciência dos usuários com diabetes mellitus acerca dos seus direitos mostrou que apesar dos avanços legalmente alcançados pelas políticas públicas, os usuários com diabetes em sua maioria desconhecem seus direitos. Desse tema, emergiram duas categorias: o (des)conhecimento dos usuários com diabetes mellitus sobre os seus direitos e a utilização não-consciente dos direitos pelos usuários com diabetes mellitus. As falas dos participantes apontam para o desconhecimento dos direitos como um direito assegurado constitucionalmente. Entretanto, há a utilização dos benefícios previstos, como por exemplo, a aquisição gratuita de medicamentos, glicosímetros e tiras para realização da monitorização da glicemia capilar. Para os participantes o benefício é entendido como um favor ou doação. Assim, para a obtenção de tais benefícios é necessário que haja uma pessoa motivadora intermediando o alcance desses. Dentre essas pessoas, eles destacam políticos, amigos e médicos. Com isso, os usuários participantes do estudo utilizam seus direitos, de maneira não-consciente, sem a compreensão de que esses são resultantes de uma política de saúde que prevê a prevenção e a atenção integral à pessoa com diabetes mellitus.

A simples existência de leis não configura a praticidade e execução das mesmas no âmbito da saúde. As leis são importantes no sentido de balizarem a consciência humana. No entanto, é preciso proteger esses direitos e criar condições para que sejam exercidos. Tendo em vista que, a informação é indispensável para o processo de construção da cidadania, emergiu o tema a co-responsabilidade em saúde no que diz respeito ao fornecimento de informações e à efetivação dos direitos dos usuários com diabetes mellitus. Três categorias configuram esse tema: o papel do poder público na divulgação das informações, as competências e responsabilidades dos profissionais de saúde: dever ético-moral em informar e a participação ou isenção dos usuários na busca por informações. Desse modo, 
existem responsabilidades as quais devem ser compartilhadas entre o poder público, os profissionais de saúde e os usuários com diabetes mellitus.

Em relação ao poder público, os participantes demonstram expectativa no que se refere à responsabilidade deste na divulgação de informações em saúde. Sugerem ainda, que e a utilização dos veículos de comunicação (rádio, televisão e jornais) deve ser utilizada como estratégia para a propagação dos direitos dos usuários com diabetes mellitus. No que se refere às responsabilidades dos profissionais da saúde em informar e orientar, as falas mostraram a queixa dos usuários entrevistados quanto à forma como essa informação é fornecida, principalmente, quando há falta de medicamentos ou insumos. Por outro lado, a responsabilidade dos usuários na busca por informações relativas à sua saúde e aos seus direitos ainda reflete falta de interesse e desconhecimento de como exercer seus direitos em situações adversas.

A humanização, como prática a ser adotada nos serviços de saúde deve configurar um ambiente, no qual princípios éticos e morais permeiem as interações entre profissionais-usuários, com o intuito de positivar tais relações. Para tanto, o tema a qualidade da interação profissional-usuário nos serviços de saúde, emergiu em decorrência da aparente insatisfação dos usuários com diabetes mellitus referente à forma como o atendimento em saúde tem acontecido. Com isso, temos duas categorias: a des(humanização) do atendimento nos serviços de saúde e a percepção da necessidade de transformação da prática assistencial.

A constituição de vínculo profissional-usuário implica na indispensável relação de escuta e responsabilização. Diante disso, as falas dos entrevistados indicam que os profissionais de saúde parecem não reconhecer as necessidades dos usuários com diabetes mellitus. Dificuldades apontadas, como o acesso a consultas médicas, a impessoalidade na relação entre profissionais de saúde-usuários, contribuem para o anseio de humanização do atendimento nos serviços de saúde. Nesse caso, é de suma importância que as práticas de saúde sejam repensadas, bem como a maneira como essas estão sendo desempenhadas. Assim, esperamos que as ações em saúde reflitam uma assistência humanizada em consonância com o que de fato o direito à saúde se propõe a oferecer. 
Ao contrário do que está preconizado na legislação vigente em diabetes mellitus, os usuários entrevistados referiram nunca terem participado de um programa de educação em diabetes. Em contrapartida, eles apontam a educação em diabetes, como um caminho para a transformação da prática assistencial. Nesse sentido, a transformação da prática assistencial deve ser orientada pelos princípios éticos e morais, com o objetivo de configurar um ambiente no qual o respeito à autonomia dos usuários com diabetes resulte na plenitude no exercício dos direitos dos usuários com diabetes mellitus.

Para tanto, é necessário que os profissionais de saúde conheçam os benefícios advindos das legislações, que vão além de distribuir gratuitamente os insumos, glicosímetros, e os medicamentos de forma regular e eqüitativa para todos os usuários com diabetes. A necessidade de prover todas as informações suficientes para que o usuário com diabetes mellitus possa tomar a melhor decisão em relação ao seu tratamento de maneira autonôma, nos remete à importância da capacitação profissional para educar, orientar e respeitar a capacidade de autonomia dos usuários.

Sem a necessária e suficiente informação, acreditamos ser difícil o usuário se sentir capaz de reivindicar e/ou lutar pelos seus direitos, dificultando, dessa forma, o exercício de sua autonomia. Promover a qualidade da assistência em saúde, por meio do respeito aos direitos dos usuários e, principalmente, por meio de ações informativas, beneficentes e justas que resultem na intensificação do exercício da autonomia desses usuários com diabetes, deve ser, portanto, a meta a ser atingida pelos profissionais de saúde.

É importante destacar que mudar os comportamentos frente às práticas de saúde é uma tarefa difícil, pois exige dos profissionais de saúde: tempo, recursos e capacitação. Ressaltamos a importância de que os líderes do governo e da saúde adotem mudanças e inovações nas políticas públicas, no sentido de reconhecer a abordagem educativa, como uma tecnologia leve a ser valorizada e implementada no atendimento dos serviços de saúde.

Ao levarmos em consideração que a Enfermagem se apresenta como um elo entre os usuários e os atuais modelos de saúde vigentes, verificamos que o fornecimento de informação adequada aos usuários de saúde nos remete à função 
social que a Enfermagem possui. Dessa forma, esperamos que os resultados aqui apresentados sobre o conhecimento dos usuários com diabetes mellitus, acerca dos seus direitos e benefícios advindos da legislação em vigor, possam contribuir para uma assistência de Enfermagem qualificada, responsável e coerente com os princípios bioéticos da beneficência, não-maleficência, justiça e respeito à autonomia dos usuários com diabetes mellitus.

Contudo, destaca-se a necessidade de novos estudos sobre a implementação dos direitos dos usuários com diabetes mellitus, no intuito de fortalecer e subsidiar o planejamento de ações efetivas, bem como servir de base para avaliar o impacto das políticas públicas em saúde. 
REFERÊNCIAS 
ABRASCO. Informação em saúde a serviço da sociedade. In: Ministério da Saúde e ABRASCO. Uso e disseminação de informações em saúde: subsídios para elaboração de uma política de informações em saúde para o SUS. Brasília. 1994. p. 27-44.

ALVES, V. S. Um modelo de educação em saúde para o Programa de Saúde da Família: pela integralidade da atenção e reorientação do modelo assistencial. Interface Comunicação, Saúde e Educação, Botucatu, vol. 9, p. 39-52, 2005.

ALVES, P. C.; LUNARDI, V. L.; LUNARDI, G. L.; LUNARDI FILHO, W. D. A percepção das enfermeiras acerca da sua atuação ante os direitos dos clientes. Revista da Escola de Enfermagem da USP, São Paulo, vol.42, n.2, p.242-8, 2008.

AMERICAN DIABETES ASSOCIATION (ADA). Diagnóstico e classificação do diabetes mellitus. Diabetes Care, v.3, n.2, p.54, jun. 2004a.

AMERICAN DIABETES ASSOCIATION (ADA). Standardizations of diabetics medical care. Diabetes Care, v.3, n.2, p.64-84, jun. 2004b.

AMERICAN DIABETES ASSOCIATION (ADA). Standards of medical care in diabetes. Diabetes Care, v.28, p.S304- S42, jan, 2005.

AMERICAN DIABETES ASSOCIATION (ADA). National standards for diabetes selfmanagement education. Diabetes care, v.32, p.S87- S94, Jan, 2009.

ANJOS, M.F. Bioética: abrangência e dinamismo. O mundo da saúde, São Paulo, v. 21, p. 4-12, 1997, São Paulo.

ANJOS, M. F. Bioética: abrangência e dinamismo. In: BARCHIFONTAINE, C. P.; PESSINI, L. Org. Bioética: Alguns desafios, São Paulo, Editora do Centro Universitário São Camilo, 2001, 347p.

ARÁUZ, A.G.; SÁNCHEZ, G; PADILLA, G.; FERNÁNDEZ, M.; ROSELLÓ. M; GUSMÁN, S. Intervención educativa sobre la diabetes en el ámbito de la atención primaria. Revista Panamericana de Salud Publica, Washington, v. 9, n. 3, p. 145$53,2001$.

ASSIS, M. M. A.; VILLA, T. C. S.; NASCIMENTO, M. A. A. Acesso aos serviços de saúde: uma possibilidade a ser construída na prática. Ciência e Saúde Coletiva, Rio de Janeiro, vol.8, p. 815-23, 2003. 
ASSUNÇÃO, M.C.F.; SANTOS, I.S.; GIGANTE, D.P. Atenção primária em diabetes no Sul do Brasil: estrutura, processo e resultado. Revista de Saúde Pública, São Paulo, v. 35, n. 1, p. 88-95, 2001.

ASSUNÇÃO, M.C.F.; SANTOS, I.S.; COSTA, J.S.D. Avaliação do processo da atenção médica: adequação do tratamento de pacientes com diabetes mellitus, Pelotas, Rio Grande do Sul, Brasil. Cadernos de Saúde Pública, Rio de Janeiro, v.18, n. 1, p. 205-11, 2002.

BALTES, M. M.; SILVERBERG, S. A. A dinâmica de dependência -autonomia no curso de vida. In: NÉRI, A. L. Psicologia do envelhecimento: temas selecionados na perspectiva do curso de vida. São Paulo: Papirus, 1995.

BANDMAN, E.; BANDMAN, B. Bioethics and human rights. Boston, University Press of America Inc., 1978. p. 265-7.

BAPTISTA, T.W.F. O direito à saúde no Brasil: sobre como chegamos no Sistema Único de Saúde e o que esperamos dele. In: VENÂNCIO, J. Políticas de saúde; Rio de Janeiro: Editora Fiocruz, 2005.

BARBOSA, R.B.; BARCELÓ, A.; MACHADO, C.A. Campanha nacional de detecção decasos suspeitos de diabetes mellitus no Brasil: relatório preliminar. Revista Panamericana de Salud Publica, Washington, v. 10, n. 5, p. 5-30, nov. 2001.

BARCELÓ, A.; RAJPATHAK, S. Índice and prevalence of diabetes mellitus in the Américas. Revista Panamericana de Salud Publica, Washington, v. 10, n. 5, p.3008, 2001.

BARROSO, L. R. Da falta de efetividade à judicialização excessiva: direito à saúde, fornecimento gratuito de medicamentos e parâmetros para atuação judicial. Revista Jurídica UNIJUS, Uberaba-MG, vol.11, n. 15, p.13-38, 2008.

BEAUCHAMP, T. L.; CHILDRESS, J. F. Princípios de Ética Biomédica. São Paulo: Edições Loyola, 1979, 574p.

BELO HORIZONTE. Lei no 8926, de 2 de agosto de 2004. Dispõe sobre os direitos dos usuários dos serviços e das ações de Saúde, no municipio. Diário Oficial do Município, Belo Horizonte, MG, 3 ago. 2004. 
BERGENSTAL, R. M.; GAVIN, J. R. The Role of Self-Monitoring of Blood Glucose in the Care of People with Diabetes: Report of a Global Consensus Conference. The American Journal of Medicine, vol.118, n.9A, p.1-6, 2005.

BERLINGUER, G. Medicina e Política. São Paulo: Hucitec; 1978, 247p.

BERLINGUER, G. Bioética Cotidiana. Brasília: Editora Universidade de Brasília; 2004, 280p.

BERNHART, M. H.; WIADNYANA, I. G. P.; WIHARDJO, H.; POHAN, I. Patient satisfaction in developing countries. Social Science \& Medicine, vol. 48, n. 8, p. 989-996, 1999.

BORGES, D. C. L. Uma análise das ações judiciais para o fornecimento de medicamentos no âmbito do SUS: o caso do estado do Rio de Janeiro no ano de 2005. 117f. Dissertação (Mestrado) - Escola Nacional de Saúde Pública Sérgio Arouca, 2007.

BOSI, M. L. M.; AFFONSO, K. C. Cidadania, participação popular e saúde: com a palavra, os usuários da Rede Pública de Serviços. Cadernos de Saúde Pública, Rio de Janeiro, vol.14, p.355-65, 1998.

BRASIL. Ministério da Saúde. Lei no 8.080, de 19 de setembro de 1990. Dispõe sobre as condições para promoção e recuperação da saúde, a organização e o funcionamento dos serviços correspondentes e dá outras providências. Diário Oficial da União, Brasília, DF, 20 set. 1990a.

BRASIL. Ministério da Saúde. Lei n 8.142, de 28 de dezembro de 1990. Dispõe sobre a participação da comunidade na gestão do Sistema Único de Saúde - SUS e sobre as transferências intergovernamentais de recursos financeiros na área da saúde e dá outras providências. Diário Oficial da União, Brasília, DF, dez. 1990b.

BRASIL. Ministério da Saúde. Portaria $n^{\circ} 176$. Estabelece critérios e requisitos para a qualificação dos municípios e estados ao incentivo à Assistência Farmacêutica Básica e define valores a serem transferidos. Diário Oficial da União, Brasília, DF, mar. 1999.

BRASIL. Ministério da Saúde. A implantação da Unidade de Saúde da Família. Brasília: Secretaria de Políticas de Saúde, 2000. 
BRASIL. Ministério da Saúde. Informe da atenção básica. Diabetes e a Reorganização da Atenção, Brasília, v. 2, n.6, p.1, fev. 2001.

BRASIL. Ministério da Saúde. Plano de reorganização da atenção à Hipertensão Arterial e ao Diabetes mellitus: manual de hipertensão arterial e diabetes mellitus. Brasília: Ministério da Saúde, 2002a.

BRASIL, Ministério da Saúde. Portaria n 371, de 6 de março de 2002. Institui o Programa Nacional de Assistência Farmacêutica para Hipertensão Arterial. Diário Oficial da União, Brasília, DF, 6 mar. 2002b.

BRASIL. Decreto no 4.726, de 09 de junho de 2003. Aprova a Estrutura Regimental e o Quadro Demonstrativo dos Cargos em Comissão e das Funções Gratificadas do Ministério da Saúde, e dá outras providências. Diário Oficial da União, Brasília, DF, 17 jun. $2003 a$.

BRASIL. Ministério da Saúde. Fundação Oswaldo Cruz. Organização PanAmericana da Saúde. Projeto Saúde 2004: Contribuição aos debates da $12^{a}$ Conferência Nacional de Saúde. Brasília: Ministério da Saúde 2003b.

BRASIL. Ministério da Saúde. Organização Pan-Americana da Saúde. Avaliação do Plano de Reorganização da Atenção à Hipertensão Arterial e ao Diabetes mellitus: manual de hipertensão arterial e diabetes mellitus. Brasília: Ministério da Saúde, 2004a.

BRASIL. Ministério da Saúde. Secretaria-Executiva. Núcleo Técnico da Política Nacional de Humanização. Humanizasus: Política Nacional de Humanização - a humanização como eixo norteador das práticas de atenção e gestão em todas as instâncias do SUS Brasília: Ministério da Saúde, 2004b.

BRASIL. Ministério da Saúde. Atenção de alta complexidade no SUS: desigualdades no acesso e no financiamento. Brasília: Ministério da Saúde, 2005.

BRASIL. Ministério da Saúde. Carta dos direitos dos usuários da saúde. Brasília: Ministério da Saúde, 2006a.

BRASIL. Ministério da Saúde. Lei no 11.347 de 27 de setembro de 2006. Dispõe sobre a distribuição gratuita de medicamentos e materiais necessários à sua aplicação e à monitoração da glicemia capilar aos portadores de diabetes inscritos em programas de educação para diabéticos. Diário Oficial da União, Brasília, DF, 28 set. $2006 b$. 
BRASIL. Ministério da Saúde. Direitos dos usuários dos serviços e das ações de saúde no Brasil: legislação compilada - 1973 a 2006. Brasília: Ministério da Saúde, 2007a.

BRASIL. Ministério da Saúde. Portaria no 2583 de 10 de outubro de 2007. Define elenco de medicamentos e insumos disponibilizados pelo SUS nos termos da Lei n¹1347, de 2006, aos usuários portadores de diabetes mellitus. Diário Oficial da União, Brasília, DF, 15 out. 2007b.

BRASIL. Ministério da Saúde. Coletânea de comunicação e informação em saúde para o exercício do controle social. Brasília: Editora do Ministério da Saúde, 2007c.

BRASIL. Ministério da Saúde. Mais Saúde: direito de todos: 2008-2011. Brasília: Editora do Ministério da Saúde, 2008.

BRODY, H. Transparency: informed consent in primary care. Hasting Centers Report. p. 5-9, sept/oct.1989.

BROWN, S. A. Studies of educational interventions and outcomes in diabetic adults: a meta-analysis revisited. Patient Educ. Couns., v. 16, p. 189-215, 1990.

BROWN, S. A. Interventions to promote diabetes self-management: state of the science. Diabetes Educator, vol.25, 6 Suppl., p.52-61, 1999.

CARVALHO, S. R. Os múltiplos sentidos da categoria "empowerment" no projeto de promoção à saúde. Cadernos de Saúde Pública, Rio de Janeiro, vol. 23, n.8, p.1835-1095, 2004.

CASSEL, E. The Sorcerer's Broom: medicine's rampant technology. Hastings Center Report, v. 23, n. 6, p. 32-39, 1993.

CHAVES, P. L.; COSTA, V. T.; LUNARDI, V. L. A enfermagem frente aos direitos de pacientes hospitalizados. Texto e Contexto, Florianópolis, vol.14, n.1, p. 38-43, 2005.

CLOTET, J. Bioética: uma ética aplicada em destaque. In: SEMINÁRIO INTERNACIONAL DE FILOSOFIA E SAÚDE, I., 1994, Florianópolis. Anais... 1994 Sociedade de Estudos em Filosofia e Saúde, 1995. p. 115-29. 
CONSELHO REGIONAL DE ENFERMAGEM DE SÃO PAULO. Principais legislações para o exercício da enfermagem. São Paulo, SP, 2007, 48 p.

COSTA, V. T.; LUNARDI, V. L.; LUNARDI FILHO, W. D. Autonomia versus cronicidade: uma questão ética no processo de cuidar em enfermagem. Revista de Enfermagem da UERJ, Rio de Janeiro, vol.15, n.1, p. 53-8, 2007.

COUTTOLENC, B. F. A dimensão econômica da saúde. In: CIANCIRULLO, T.I.; CORNETTA, V. K. Saúde, desenvolvimento e globalização: um desafio para os gestores do terceiro milênio. São Paulo: Ícone; 2002.

DAMATTA, R. Carnavais, malandros e heróis - para uma sociologia do dilema brasileiro. Rio de Janeiro, Rocco, 1997, 272p.

DAMATTA, R. O que faz o Brasil, Brasil? Rio de Janeiro, Rocco, 2000, 126p.

DAVIS, W.A.; KNUIMAN, M.W.; HENDRIE, D.M.A.;DAVIS, T.M.E. Determinants of diabetes-attributable non-blood glucose-lowering medications costs in type 2 diabetes: the Fremantle Diabetes Study. Diabetes Care, v. 28, n. 2, p. 329-36, feb. 2005.

DEAKIN, T.; MCSHANE, C. E.; CADE, J. E. et al. Review: group based education in self management strategies improves outcomes in type 2 diabetes mellitus. Cochrane Database Syst Rev, vol.2, CD003417, 2005.

DELAMATER, A. M. Improving patient adherence. Clinical Diabetes, vol. 24, p. 717, 2006.

DESLANDES, S. F. A ótica de gestores sobre a humanização na assistência nas maternidades municipais do Rio de Janeiro. Ciência e Saúde Coletiva, Rio de Janeiro, vol.10, n.3, p.615-626, 2005.

DIABETES CONTROL AND COMPLICATIONS TRIAL- (DCCT) .Research group: the effect of intensive treatment of diabetes on the development and progression of long term complications in IDDM. New England Journal of Medicine, Andover, n.329, p.977-86, 1993.

DINSDALE, G. B.; MANSON, D. B.; SCHIMIDT, F.; STRICKLAND, T. Metodologia para medir a satisfação do usuário no Canadá: desfazendo mitos e redesenhando roteiros. Brasília, ENAP, nº 20, 2000. 
DRANE, J.; PESSINI, L. Bioética, medicina e tecnologia desafios éticos na fronteira do conhecimento humano. São Paulo: Edições Loyola, 2005, 250 p.

DURANT, G. A bioética: natureza, princípios e objetivos. São Paulo: Paulus, 1995.

ELIAS, P. E. Estrutura e organização da atenção à saúde no Brasil. In: COHN A, E.P.E. Saúde no Brasil: políticas e organização de serviços. 3 ed. São Paulo: Cortez/CEDEC, 1999. p.59-133.

ENGELGAU, M.E.; NAYARAN, K.M.; HERMAN, W.H. Screening for type 2 diabetes.Diabetes Care, v. 23, n. 10, p. 1563-80, 2000.

ERDMANN, A. L, BACHES, D. E.; KLOCH, P.; KOERICH, M.S.; RODRIGUES, A. C. R. L.; DRAGO, L. C. Discutindo o significado de cidadania a partir dos direitos dos usuários da Saúde. Revista de Enfermagem da UERJ, Rio de Janeiro, vol. 16, n. 4, p.477-81, 2008.

EXPERT COMMITTEE on the diagnosis and classification of diabetes mellitus: Follow-up report on the diagnosis of diabetes mellitus. Diabetes Care, v. 26, p. 3160-7, 2003.

FAGUNDES, S. Apresentação. In: ORTIZ, J. N.; BORDIGNON, M. O; GRALHA, R. S.; FAGUNDES, S.; CORADINI, S. R. organizadores. Acolhimento em Porto Alegre: um SUS de todos para todos. Porto Alegre: Prefeitura Municipal de Porto Alegre; 2004. p. 11-2.

FARIA, H.T.G. Fatores relacionados à adesão do paciente diabético à terapêutica medicamentosa. 146 f. Dissertação (Mestrado) - Escola de Enfermagem de Ribeirão Preto da Universidade de São Paulo, 2008.

FETTERS, M.D.; BRODY, H. The epidemiology of bioethics. The Journal of Clinical Ethics, v. 10, p. 107-15, 1999.

FONG, D. S.; AIELLO, L. P.; FERRIS, F.L.; KLENIN, R. Diabetic retinopathy. Diabetes Care, v. 27, p.2540-53, 2004.

FORTES, P.A.C. Qualidade dos serviços de saúde: o planejamento, a gestão e o usuário. In: CONGRESSO BRASILEIRO DE ENFERMAGEM, 46., 1994, Porto Alegre. Anais... Porto Alegre: ABEn, 1994. p. 133-138. 
FORTES, P. A. C. Critérios éticos em microalocação de escassos recursos em saúde. In: BARCHIFONTAINE, C. P.; PESSINI, L. Bioética: alguns desafios. São Paulo, Editora do Centro Universitário São Camilo, 2001, 347p.

FORTES, P. A. C.; ZOBOLI, E. L. C. P. Bioética e saúde pública. Saõ Paulo: Edições Loyola, 2003, 167p.

FORTES, P.A.C. Ética, direitos dos usuários e políticas de humanização da atenção à saúde. Saúde e sociedade. V.13, n.3, p. 30-35, set-dez 2004.

FORTES, P. A. C. Ética e saúde: questões éticas, deontológicas e legais tomada de decisões, autonomia e direitos do paciente, estudos de caso. São Paulo: EPU, 2005.

FRANCO, L. J.; ROCHA, J. S. Y. O aumento das hospitalizações por diabetes mellitus na região de ribeirão Preto, no período 1988-97. Diabetes Clínica, v. 6, n.2, p.108, mar.labr. 2002.

FRANZ, M. J.; BANTLE, J. P.; BEEBE, C. A.;BRUNZELL, J. D.; CHIASSON, J. L..;GARG, A.; HOLZMEISTER, L. A.; HOOGWERF, B.; MAYER-DAVIS, E.; FRIEDMAN,M. Teaching about and for family diversity in nursing. Journal of family nursing, v. 3, n. 3, p. 280-94, 1997.

GAIOSO, V. P. Satisfação do usuário na perspectiva da aceitabilidade no cenário da saúde da família no município de Ribeirão Preto - SP. 152 f. Dissertação (Mestrado) - Escola de Enfermagem de Ribeirão Preto da Universidade de São Paulo, 2007.

GARRAFA, V. Desafios éticos na política de Recursos Humanos frente às necessidades de saúde. Cad. RH Saúde, Brasília, v.1, n.3, 1993.

GARRAFA, V. Dimensão da ética em saúde pública. São Paulo: Faculdade de Saúde Pública/USP, 1995.

GARRAFA, V.; OSELKA, G.; DINIZ, D. Saúde pública, bioética e equidade. Bioética. v.5, n.1, p. 27-33, 1997.

GAUDERER, E.C. Os direitos do paciente. 7. ed. Rio de Janeiro: Record, 1998. 
GASTAL, C. L. C.; GUTFREIND, C. Um estudo comparativo de dois serviços de saúde mental: relações entre participação popular e representações sociais relacionadas ao direito à saúde. Cadernos de Saúde Pública, Rio de Janeiro, v.23, n.8, 2007.

GENTILLI, V. Democracia de massas: jornalismo e cidadania. Estudo sobre as sociedades contemporâneas e o direito dos cidadãos à informação. Porto Alegre: EDIPUCRS, 2005, 180p.

GRACIA, D. Fundamentos de Bioética. Madrid: Eudema; 1989.

GRACIA D. Fundamentación y enseñanza de la bioética. Santa Fé de Bogotá: El Buho, 1998a.

GRACIA D. Bioética clínica. Santa Fé de Bogotá: El Buho, 1998b.

GRUPO DE ESTUDO DE LA DIABETES EN LA ATENCIÓN PRIMARIA DE SALUD (GEDAPS). Guía para el tratamiento de la diabetes tipo 2 en la atención primaria: contribución al programa de acción de la Declaración de St. Vicente. Harcourt, 2000.

GOLDIN, J. R.; FRANCESCONI, C.F. In: CLOTET, J; FEIJÓ, A.G.S; OLIVEIRA, M.G. (Coord.). Bioética: uma visão panorâmica. Porto Alegre: EDIPUCRS, 2005.

GOLDNEY, R. D.; PHILLIPS, P.J.; FISHER, L. J.; WILSON, D. H. Diabetes, depression and quality of life: a population study. Diabetes Care, v. 27 n.5, p. 106670, 2004 may.

GROSS, J. L.; AZEVEDO, M. J.; SILVEIRO, S. P.; CANANI, L. H.; CARAMORI, M. L.; ZELMANOVITZ, T. Diabetic nephropathy: diagnosis, prevention, and treatment. Diabetes Care, v. 28, p. 164-76, 2005

GUILLET, S. E. Understanding cronic illness or disability. In: NEAL, J.L.; GUILLET, S.E.(Ed.). Care of the adult with a chronic illness or disability. Philadelphia: Elsevier Mosby, 2004. p. 1-10.

HENNINGTON, E. A. Acolhimento como prática interdisciplinar num programa de extensão universitária. Cadernos de Saúde Pública, Rio de Janeiro, v. 21, n. 1, 2005. 
HOFFMAN, F. F.; BENTES, F. R. N. M. A Litigância Judicial dos Direitos Sociais no Brasil: uma Abordagem Empírica. In: SOUZA NETO, C. P.; SARMENTO, D. (Coords.). Direitos Sociais. Rio de Janeiro: Lumen Juris, 2008.

HOLMSTRÖM, I.M.; ROSENQVIST, U. Misunderstandings about illness and treatment among patients with type 2 diabetes. Journal of Advanced Nursing, v.49, n. 2, p.146-54, 2005.

HOOD, K.K.; BUTLER, D. A.; VOLKENING, L. K.; ANDERSON, B. J.; LAFFEL, L. M. The blood glucose monitoring communication questionnaire: an instrument to measure affect specific to blood glucose monitoring. Diabetes Care, v. 27, n.11, p. 2610-5, 2004 nov.

HULKA, B. S.; WHEAT, J.R. Patterns of utilization: the patient perspective. New England Journal of Medicine, vol. 23, n.5, p.438-460, 1985.

INTERNATIONAL DIABETES FEDERATION. Complicações do diabetes e educação. Diabetes Clínica, Rio de Janeiro, v.6, n.3, p. 217-220, maio/jun. 2002.

JOHNSON, S.L.; TABAEI, B.P.; HERMAN, W.H. The efficacy and cost of alternative strategies for systematic screening for type 2 diabetes in the U.S. population 45-74 years of age. Diabetes Care, v. 28, n. 2, p. 307-11, feb. 2005.

KARTER, A. J., FERRARA, A.; DARBINIAN, J. A, et al. Self-Monitoring of Blood Glucose: language and financial barriers in a managed care population with diabetes. Diabetes Care, vol.23, p.477-483, 2000.

LESSA, I. O adulto brasileiro e as doenças crônicas da modernidade: epidemiologia das doenças crônicas não transmissíveis. São Paulo: HUCITEC, 1998. 284p.

LEITE, S. N.; VASCONCELLOS, M. P. C. Adesão à terapêutica medicamentosa: elementos para a discussão de conceitos e pressupostos adotados na literatura. Rev. Ciência \& Saúde Coletiva, v. 8, n. 3, p. 775-782, 2003.

LOPES, J. R. L. Direitos Sociais: teoria e prática. São Paulo: Método, 2006.

LUBKIN, I. M.; LARSEN, P. D. Chronic Illness: impact and interventions. Massachussets: Jones and Bartlett Publishers, 2002. 
LUNARDI, V. L.; SOARES, N. V. Os direitos do cliente como uma questão ética. Revista Brasileira de Enfermagem, vol. 55, n.1, p.64-69, 2002.

LIMA, A. A,; ZANETTI, M. L.; MIYAR, L. O.; MACHADO, M. P. S.; SANTOS, M. A. Fatores facilitadores/dificultadores na implementação de um programa educativo por equipe multidisciplinar. Diabetes Clínica, v. 8, n. 6, p. 443-48, 2004.

MAFRA, A. C. Que direito? Trajetórias e percepções dos usuários no processo de acesso a medicamentos por mandatos judiciais em Santa Catarina. Revista Ciência e Saúde Coletiva da Associação Brasileira de Pós-Graduação em Saúde Coletiva, 2007. Disponível em: www.abrasco.org.br/cienciaesaudecoletiva/artigos/ artigo_int.php?id_artigo=2155. Acesso em 10/05/09.

MAYER-BRAUNACK, A. J. What makes a problem an ethical problem? An empirical perspective on the nature of ethical problems in general practice. Journal of Medical Ethics, v. 27, p. 98-103, 2001.

MALERBI, D.; FRANCO, L.J. The Brazilian Cooperative Group on the Study of Diabetes Prevalence. Multicenter Study of the Prevalence of Diabetes Mellitus and Impaired Glucose Tolerance in the urban Brazilian population aged 30-69 years. Diabetes Care, v. 15, n. 11, p. 1509-16, 1992.

MARCHI, M. M.; SZTAJN, R. Autonomia e Heteronomia na Relação entre Profissional de Saúde e Usuário dos Serviços de Saúde. Revista Bioética, vol. 6, n1, p. 39-45, 1998.

MARQUES, S. B.; DALLARI, S. G. Garantia do direito social à assistência farmacêutica no Estado de São Paulo. Revista de Saúde Pública, Rio de Janeiro, vol. 41, n.1, p.101-107, 2007.

MAUÉS, A. G. M.; LEITÃO, A. F. B. Dimensões da Judicialização da Política no Brasil: As ADIns dos Partidos Políticos. In: Scaff, Fernando Facury. (Org.). Constitucionalizando Direitos: 15 Anos da Constituição Brasileira de 1988. 1 ed. Rio de Janeiro: Renovar, 2003, v. , p. 3-40.

MERHY, E. E. A perda da dimensão cuidadora na produção de saúde: uma discussão do modelo assistencial e da intervenção no seu modo de trabalhar a assistência. In: Campos CR, organizador. Sistema Único de Saúde em Belo Horizonte: reescrevendo o público. São Paulo: Editora Xamã; 1998. p. 103-20. 
MESSEDER, A. M.; OSÓRIO-DE-CASTRO, C. G. S.; LUIZA, V. L. Mandados judiciais como ferramenta para garantia do acesso a medicamentos no setor público: a experiência do Estado do Rio de Janeiro, Brasil. Cadernos de Saúde Pública, Rio de Janeiro, vol.21, n.2, p.525-534, 2005.

MILECH, A. Perspectivas no tratamento do diabetes mellitus. Diabetes \& Metabolismo, São Paulo, n. 4, p. 170-171, 1998.

MINAYO, M. C. de S. Ciência, técnica e arte o desafio do pesquisa social. In: MINAYO, M.C. de S. Pesquisa social: teoría, método e criatividade. 19. ed. Petrópolis: vozes, 2001. p. 9-30.

NARAYAN, K.M.V., BOYLE, J.P, THOMPSON, T.J., SORENSEN, S.W., WILLIAMSON, D.F. Life time Risk for Diabetes Mellitus in the United States. JAMA, v. 290, n. 14, p. 1884-90, 2003.

NISSINEN, A.; BERRIOS, X; PUSKA, P. Intervenciones comunitárias contra lãs enfermedades no transmisibles: leccione de los paises desarrollados para los paises em desarrollo. Bol. Org. Panam. Salud, v. 6, p. 47 - 53, 2002.

NORRIS, S. L.; ENGELGAU, M. M., NARANYAN, K. M. V. Effectiveness of selfmanagement training in type 2 diabetes: a systematic review of randomized controlled trials. Diabetes Care, vol. 24, p.561-587, 2001.

NORRIS, S. L.; LAU, J.; SMITH, S. J.; SCHMID, C. H.; ENGELGAU, M. M. Selfmanagement education for adults with type 2 diabetes: a meta-analysis on the effect on glycemic control. Diabetes Care, vol.25, p.1159-1171, 2002.

NORRIS, S. L. Self-management education in type 2 diabetes. Practical Diabetology, vol.22, p.713, 2003.

NUNES, L. Usuários dos serviços de saúde e os seus direitos. Revista Brasileira de Bioética, vol.2, n.2, p. 201-219, 2006.

NUNES, M. D. R.; DUPAS, G; FERREIRA, N. M. L. A. Diabetes na infância/adolescência: conhecendo a dinâmica familiar. Revista Eletrônica de Enfermagem, vol. 9, n.1, p.119-130, 2007.

OLIVEIRA, F. Bioética: uma face da cidadania. São Paulo: Moderna, 1997. 
ORGANIZAÇÃO MUNDIAL DA SAÚDE. Key informant survey. 2000. Disponível em: www3.who.int/whosis/menu.cfm?path=whosis. Acesso em: 07/04/09.

ORGANIZAÇÃO MUNDIAL DA SAÚDE. Perspectivas políticas sobre medicamentos de la OMS: Selección de Medicamentos Esenciales. Genebra: OMS, 2002a.

ORGANIZAÇÃO MUNDIAL DA SAÚDE. The cost of diabetes. Geneva, 2002b. Disponível em: http://111.who.int/mediacentre/factsheets/fs236/em/. Acesso em: 26 maio 2008.

ORGANIZAÇÃO MUNDIAL DA SAÚDE. Cuidados inovadores para condições crônicas: componentes estruturais de ação: relatório mundial. Brasília: OMS, 2003. $105 \mathrm{p}$.

ORGANIZACIÓN PANAMERICANA DE SALUD - ORGANIZACIÓN MUNDIAL DE LA SALUD. Bioética. Cuadernos del Programa Regional de Bioética para América Latina e Caribe, $n^{\circ} .1$, set. 1995.

ORGANIZAÇÃO PAN-AMERICANA DA SAÚDE. CARMEN: iniciativa para a prevenção integrada de doenças não-transmissíveis nas Américas. Brasília: OPAS, 2003.

ORGANIZAÇÃO PAN-AMERICANA DA SAÚDE. Passo a passo no controle de diabetes, Republica Dominicana, 2004. Disponível em: <http://www.paho.org/ Spanish/AD/DPC/NC/diabrochure-2004.htm>. Acesso em: 12 fev. 2008.

OSTERBERG, L.; BLASCHKE, T. Adherence to medication. The New England Journal of Medicine, v. 353, n. 5, p. 487-97, ago 2005.

PAIVA, D. C. P.; BERSUSA, A. A. S.; ESCUDER, M. M. Avaliação da assistência ao paciente com diabetes e/ou hipertensão pelo Programa Saúde da Família do Município de Francisco Morato, São Paulo, Brasil. Cadernos de Saúde Pública, Rio de Janeiro, vol. 22, n.2, p.377-385, 2006.

PARASURAMAN, A.; ZEITHALML, V. A.; BERRY, L. SERVQUAL: a multiple item scale for measuring customer perceptions of service quality. Journal of Retailing, vol.64, p.12-40, 1988. 
PEGORARO, O. A. O lugar da bioética na história da ética e no conceito de justiça como cuidado. In: PESSINI, L.; BARCHIFONTAINE, C. P. Bioética e longevidade humana. São Paulo: Centro Universitário São Camilo: Edições Loyola, 2006, 560p.

PELLEGRINI FILHO, A. Pesquisa em saúde, política de saúde e eqüidade na América Latina, Ciência \& Saúde Coletiva, Rio de Janeiro, vol.9, n.2, p.339-350, 2004.

PESSINI, L.; BARCHIFONTAINE, C. de P. Problemas atuais de bioética. São Paulo, 2000.

PESSINI, L.; BARCHIFONTAINE, C. de P. Problemas atuais de Bioética. 6 ed. São Paulo: Loyola, 2002.

PINSKY, J; PINSKY, C. B. História da cidadania. $2^{a}$ Ed. São Paulo. Contexto, 2003, 591p.

PINHO, I. C.; SIQUEIRA, J. C. B. A.; PINHO, L. M. O. As percepções do enfermeiro acerca da integralidade da assistência. Revista Eletrônica de Enfermagem, vol.8, n.1, p. 48-51, 2006.

POPE, C.; MAYS, N. Pesquisa qualitativa na atenção à saúde. 2. ed. Porto Alegre: Artmed, 2005.

POTTER, V.R. O mundo da saúde. 1998; 22: 370-374. [apresentado no IV Congresso Mundial de Bioética]; 1998, Nov 04-07; Tóquio.

PUCCINI, P. T; CECÍLIO, L. C. O. A humanização dos serviços e o direito à saúde. Cadernos de Saúde Pública, Rio de Janeiro, vol.20, n.5, p.1342-1353, 2004.

REIS, A. O. A; MARAZINA, I. V. M.; GALLO, P. R. A humanização na saúde como instância libertadora. Saúde e Sociedade, vol. 13, n.3, p. 36-43, 2004.

RENDERS, C. M., VALK, G. D.; GRIFFIN, S. J.; WAGNER, E.; EIJK VAN, J. T.; ASSENDELFT, W. J. Interventions to improve the management of diabetes in primary care, out patient, and community settings: a systematic review. Diabetes Care, vol.24, p.1821-1833, 2001. 
RIBEIRÃO PRETO. Lei $n^{\circ} 10.299$, de 22 de dezembro de 2004. Dispõe sobre as normas de proteção à pessoa diabética incluindo o fornecimento de medicamento $\mathrm{e}$ a monitorização da glicemia capilar aos usuários diabéticos cadastrados em programas de educação em diabetes. Diário Oficial do Município, Ribeirão Preto, SP, 23 dez. 2004.

RIBEIRÃO PRETO. Secretaria Municipal da Saúde. Protocolo de atendimento em hipertensão e diabetes, 2006. Acessado em: 25 fev. 2008. Disponível em: http://www.ribeiraopreto.sp.gov.br/ssaude/programas/hipertensao/prot-hipertensao. pdfv.

ROBILLARD, H.M.; HIGH, D.M.; SEBASTIAN, J.G.; PISANESCHI, J.I.; PERRITT, L.J.; MAHLER, D.M. Ethical issues in primary health care: a survey of practioners' perceptions. Journal of Community Health, v. 14, p. 9-17, 1989.

SANTOS, L.R.; EIDT, O.R. Os direitos do cidadão usuário do Sistema Único de Saúde: um enfoque da Bioética na Saúde Coletiva. Acta Paulista de Enfermagem, São Paulo, v. 17, n. 3, 2004.

SANTOS, E. C. B.; ZANETTI, M. L.; MIYAR, L. O.; SANTOS, M. A. O cuidado à pessoa diabética sob a ótica do paciente e de seus familiares. Revista Latinoamericana de Enfermagem, Ribeirão Preto, v. 13, n. 3, p. 397-406; maio/jun. 2005.

SÃO PAULO. Lei no 10.241 de 17 de março de 1999. Dispõe sobre os direitos dos usuários dos serviços e das ações de saúde no Estado e dá outras providências. Diário Oficial do Estado, São Paulo, SP, 18 mar. 1999. Seção 1, p.1

SÃO PAULO. Lei n`10.782, de 9 de março 2001. Define diretrizes para uma política de prevenção e atenção integral à saúde da pessoa portadora de diabetes, no âmbito do Sistema Único de Saúde e dá outras providências. Diário Oficial, São Paulo, SP, 10 mar. 2001.

SAWYER, D. O.; LEITE, I. C.; ALEXANDRINO, R. Perfis de utilização de serviços de saúde no Brasil. Ciência \& Saúde Coletiva, Rio de Janeiro, vol.7, n.4, p.757-776, 2002.

SCHRAMM, J.M.A.; OLIVEIRA, A.F.; LEITE, I.C.; VALENTE, J.G.; GADELHA, A.M.J.; PORTELA, M.C.; CAMPOS, M.R. Transição epidemiológica e o estudo de carga de doença no Brasil. Ciência \& Saúde Coletiva, Rio de Janeiro, v. 9, n.4, p. 897-908, 2004. 
SELLI, L. Bioética na enfermagem. São Leopoldo, RS: Unisinos; 2003.

SELLI, L.; VIAL, E. A. Justiça como autonomia dos indivíduos. Revista Brasileira de Bioética, vol. 2, n.3, p.328-340, 2006.

SILVA, R. C. S. Medicamentos excepcionais no âmbito da assistência farmacêutica no Brasil. Dissertação (Mestrado) - Fundação Oswaldo Cruz, Escola Nacional de Saúde Pública, 2000. 215 p.

SILVA, S. A. Direitos Sociais. Leis Orçamentárias como Instrumento de Implementação. Curitiba: Juruá, 2007.

SOCIEDADE BRASILEIRA DE DIABETES. Diretrizes para Tratamento e acompanhamento do diabetes mellitus, 2006.

SOCIEDADE BRASILEIRA DE DIABETES. Tratamento e acompanhamento do diabetes mellitus, 2007.

SOCIEDADE BRASILEIRA DE DIABETES. Diretrizes da Sociedade Brasileira de Diabetes, 2008.

SOUZA, M. L. P; GARNELO, L. "É muito dificultoso!": etnografia dos cuidados a pacientes com hipertensão e/ou diabetes na atenção básica, em Manaus, Amazonas, Brasil. Cadernos de Saúde Pública, Rio de Janeiro, 24 Sup, n.1, p.591599, 2008.

SOUZA, E. C. F.; VILAR, R. L. A.; ROCHA, N. S. P. D.; UCHOA, A. C.; ROCHA, P. M. Acesso e acolhimento na atenção básica: uma análise da percepção dos usuários e profissionais de saúde. Cadernos de Saúde Pública, Rio de Janeiro, 24 Sup, n1, p.100-110, 2008.

STARFIELD, B. Atenção primária: equilíbrio entre necessidades de saúde, serviços e tecnologia. Brasília: Organização das Nações Unidas para a Educação, a Ciência e a Cultura/Ministério da Saúde; 2004.

TEIXEIRA, R. R. O acolhimento num serviço de saúde entendido como uma rede de conversações. In: Pinheiro R, Mattos RA. Construção da integralidade: cotidiano, saberes e práticas em saúde. Rio de Janeiro: Instituto de Medicina Social, Universidade do Estado do Rio de Janeiro/ABRASCO; p. 49-61. 2003. 
TEIXEIRA, C. R. S. ZANETTI, M. L. O trabalho multiprofissional com grupo de diabéticos. Revista Brasileira de Enfermagem, Brasília, DF, vol.59, n.6, p.812-17, 2006.

TORQUATO, M.T.C.G.; MONTENEGRO Jr, R.N.; VIANA, L.A.L.; SOUZA, R.A.H.G.; IANNA, C.M.M.; LUCAS, J.C.B. et al. Prevalence of diabetes mellitus and impaired glucose tolerance in the urban population aged 30-69 years in Ribeirão Preto (São Paulo), Brazil. São Paulo Medical Journal, v. 121, n. 6, p. 224-30, 2003.

TOVAR, M. T. Participação e controle social para o exercício pleno da cidadania em saúde na América Latina: importância da comunicação e da informação. In: Coletânea de comunicação e informação em saúde para o exercício do controle social. Brasília: Editora do Ministério da Saúde, 2007.

TRAVASSOS, C.; MARTINS, M. Uma revisão sobre os conceitos de acesso e utilização de serviços de saúde, Cadernos de Saúde Pública, Rio de Janeiro, 20 Sup. 2, p. 190-198, 2004.

TRAVERSO-YÉPEZ, M.; MORAIS, N. A. Reivindicando a subjetividade dos usuários da Rede Básica de Saúde: para uma humanização do atendimento. Cadernos de Saúde Pública, Rio de Janeiro, vol. 20, n.1, p.80-88, 2004.

TRIVIÑOS, A. N. S. Introdução à pesquisa em ciências sociais: a pesquisa qualitativa em educação. São Paulo: Atlas, 1995. 175p.

TUOMILEHTO, J.; LINDSTROM, J.; ERIKSSON, J. G.; VALLE, T. T.; HAMALAINEN,H.; ILANNE-PARIKKA, P.; J. et al. Prevention of type 2 diabetes mellitus by changes in life style among subjects with impaired glucose tolerance. $\mathbf{N}$. Engl. J. Med., v. 344, p. 1343-50, 2001.

UNITED KINGDOM PROSPECTIVE DIABETES STUDY GROUP (UKPDS). Intensive blood-glucose control with sulfonylureas or insulin compared with conventional treatment and risk of complications in patients with type 2 diabetes: UKPDS 33.Lancet, New York, v.352, p.837-853, 1998.

VAISTMAN, J.; ANDRADE, G. R. B. Satisfação e responsividade: formas de medir a qualidade e a humanização da assistência à saúde. Ciência \& Saúde Coletiva, vol. 10, n.3, p.599-613, 2005. 
VALLE, E. A.; VIEGAS, E.C.; CASTRO, C.A.C.; TOLEDO JR, A. C. A adesão ao tratamento. Revista Brasileira de Clínica Terapêutica, v. 26, n. 3, p. 83-6, maio 2000.

VARALDO, C. O melhor hospital. O Globo, 22 out. 2003. Caderno 1, p.6.

VÁSQUEZ, M. L.; SILVA, M. R. F.; CAMPOS, E. S.; et al. Participação social nos serviços de saúde: concepções dos usuários e líderes comunitários em dois municípios do Nordeste do Brasil. Cadernos de Saúde Pública, Rio de Janeiro, vol. 19, n.2, p.579-591, 2003.

VELOSO, R. C.; FERREIRA, M. A. Representações sociais da cidadania e seus nexos com as ações dos usuários de um serviço de saúde. Revista de Enfermagem UERJ, Rio de Janeiro, vol.15, n.4, p.527-32, 2007.

VELOSO, R. C.; ESPÍNDOLA, T. A percepção do cliente hospitalizado acerca de seus direitos e deveres. Revista de Enfermagem UERJ, Rio de Janeiro, vol.13, 1, p. 38-43, 2005.

VIEIRA, F. S. ZUCHI, P. Distorções causadas pelas ações judiciais à política de medicamentos no Brasil. Revista de Saúde Pública, São Paulo, vol.41, n.2, p.21422, 2007.

WENNBERG, J.E. On patient need, equity, supplier-induced demand, and the need to assess the outcome of common medical practices. Medical Care, vol. 23, n.5, p. 512-520, 1985.

WASSERMAN, D. H.; ZINMAN, D. Exercise in individuals with IDDM. Diabetes Care, v.17, p. 924-37, 1994.

WIKLER, D. Bioethics and social responsibility. Bioethics, vol.11, p.185-6, 1997.

WILD, S.; ROGLIC, G.; GREEN, A.; SICREE, R.; KING, H. Global prevalence of diabetes: estimates for the year 2000 and projections for 2030. Diabetes Care, v. 27, n. 5, p. 1047-53, 2004.

ZANETTI, M.L. O cuidado com a pessoa diabética no Centro Educativo de Enfermagem para Adultos e Idosos. 91 f. Tese (Livre Docência) - Escola de Enfermagem de Ribeirão Preto da Universidade de São Paulo, 2002. 
ZANETTI, M. L.; BIAGG, M. V.; SANTOS, M. A.; PÉRES, D. S.; TEIXEIRA; C. R. S. $\mathrm{O}$ cuidado à pessoa diabética e as repercussões na família. Revista Brasileira de Enfermagem, Brasília, vol. 61, n. 2, p. 186-192, 2008.

ZOBOLI, E. L. C. P. Bioética e atenção básica: um estudo de ética descritiva com enfermeiros e médicos do Programa de Saúde da Família. 253 f. Tese (Doutorado) - Faculdade de Saúde Pública, Universidade de São Paulo, São Paulo, 2003.

ZOBOLI, E. L. C. P.; FORTES, P. A. C. Bioética e atenção básica: um perfil dos problemas éticos vividos por enfermeiros e médicos do Programa Saúde da Família, São Paulo, Brasil. Cadernos de Saúde Pública, Rio de Janeiro, vol.20, n.6, p.169099, 2004. 
APÊNDICES 


\section{APÊNDICE A}

\section{Instrumento de coleta de dados}

Pesquisa: Direitos dos usuários com diabetes mellitus: do conhecimento à utilização dos benefícios na saúde.

Data da entrevista: __ _ _ _

Inicio da entrevista:
Entrevistador:

Término da entrevista:

\section{Parte I - Variáveis sócio-demográficas}
1) Sexo:
( ) 1. Feminino
( ) 2. Masculino

2) Idade: anos completos

3) Escolaridade:
( ) A. Analfabeto
( ) B. Primeiro grau incompleto
( ) C. Primeiro grau completo
( ) D. Segundo grau incompleto
( ) E. Segundo grau completo
( ) F.Superior Incompleto
( ) G. Superior (universitário) completo
( ) H. Nunca foi à escola

4) Estado civil:
( ) A. Solteiro(a)
( ) B. Casado(a)
( ) C. Mora com companheiro(a)
( ) D. Separado(a)
( ) E. Viúvo(a)

5) Renda familiar:
( ) A. até 2 salários mínimos
( ) B. 3 salários mínimos
( ) C. 4 salários mínimos
( ) D. 5 salários mínimos
( ) E. 6 salários mínimos
( ) F. mais de 7 salários mínimos

6) Ocupação:
( ) A. Desempregado
( ) B. Do lar
( ) C. Estudante
( ) D. Aposentado
( ) E. Trabalhador assalariado
( ) F. Empregado doméstico
( ) G. Pequeno produtor rural
( ) H. Profissional liberal autônomo
( ) I. Empresário
( ) J. Funcionário público
Outros: 


\section{Parte II - Variáveis Clínicas}

1) Tipo de diabetes:

tipo $1($ )

tipo $2($ )

gestacional ( )

não sabe informar ( )

2) Tempo de doença: anos completos

3) Última consulta médica: (mês) (ano)

4) Tratamento atual: (pode ser assinalado mais de uma resposta)
( ) antidiabético oral
( ) insulina
( ) dieta
( ) exercício físico

5) Como a medicação foi obtida?
( ) Farmácia particular
( ) Farmácia do convênio $\%$ desconto
( ) Farmácia popular
( ) Unidade Básica de Saúde/SUS
( ) Outros

6) Instituição de saúde para acompanhamento
A. Unidade Básica de Saúde
B. Unidade Básica Distrital de Saúde
Sim
Não
C. Ambulatório HCFMRP - USP
D. Conveniada
E. Consultório particular
()
()
()
()

Parte III - Variáveis relacionadas à monitorização da glicemia capilar

1) Faz medidas da glicemia capilar ou ponta de dedo?( Se não pule para a questão $n^{\circ} 13$ ) ( ) Sim ( )Não.

2) Como obteve o monitor de glicemia?

3) Ganhou as tiras para a realização de glicemia capilares nos últimos meses?
( ) Sim
( )Não

4) Participa de algum programa educativo?
( ) Sim
( )Não

5) Onde?

6) Há quanto tempo? 


\section{APÊNDICE B}

Pesquisa: Direitos dos usuários com diabetes mellitus: do conhecimento à utilização dos benefícios na saúde.

Data da entrevista: ___ _ _

Duração:

Entrevistador:

\section{Roteiro de Entrevista Semi-Estruturada}

Questão disparadora: Quais as informações que o(a) senhor(a) possui acerca de seus direitos relacionados ao diabetes e como tem utilizado os mesmos?

- Conhecimento sobre direitos/reivindicações/cidadania/autonomia.

- Fornecimento universal/justiça distributiva/conflito ético.

- Aquisição de medicamentos/insulina

- Aquisição de materiais e aparelho.

- Utilização de insumos; lancetas, seringas e fitas.

- Monitorização capilar.

- Atendimento oferecido na Unidade Básica de Saúde (UBS).

- Dificuldades sentidas no acesso à UBS, aos medicamentos e insumos.

- Fonte de informações (médico, enfermeiro, farmacêutico, agente comunitário de saúde).

- Programas de educação.

- Papel do governo na saúde. 


\title{
APÊNDICE C
}

\author{
Universidade de São Paulo \\ Escola de Enfermagem de Ribeirão Preto \\ Departamento de Enfermagem Geral e Especializada
}

\section{Termo de Consentimento Livre e Esclarecido}

Meu Nome é Ellen Cristina Barbosa dos Santos e sou aluna do curso de Mestrado da PósGraduação da Escola de Enfermagem de Ribeirão Preto. Estou desenvolvendo uma pesquisa sobre o que os usuários com Diabetes mellitus conhecem sobre os seus diretos e como utilizam os mesmos. A pesquisa será realizada na casa 5 - Centro Educativo em Enfermagem para adultos e Idosos localizada no Campus da Universidade de São Paulo, em horário previamente combinado nas terçasfeiras. A duração da entrevistas dependerá da sua disponibilidade e será feita por mim e, se você concordar, gravarei para que eu possa ter a sua integral opinião. As gravações serão destruídas após a análise do conteúdo. Sua identificação será mantida em sigilo e os resultados da pesquisa serão apresentados em minha dissertação e em revistas científicas. Caso você tenha dúvidas, estarei à disposição para esclarecimentos. Você pode desistir de participar dessa pesquisa a qualquer momento, sem prejuízos, bastando para isso me comunicar.

Ellen Cristina Barbosa dos Santos

Pesquisadora responsável pela pesquisa

Rua Álvares Cabral, 1152, Ap 62

Centro, Ribeirão Preto - SP

Fone: (16) 91575859
Carla Regina de Souza Teixeira

Prof. Dra. Orientadora da pesquisa

Fone: (16)3602 3420

Reclamações: com os pesquisadores ou no Comitê de Ética e Pesquisa da Escola de Enfermagem de Ribeirão Preto, pelo Fone: (16)36023386.

Li, compreendi, recebi uma cópia e concordo em participar voluntariamente da pesquisa.

Assinatura do participante: 


\section{Parecer do Comitê de Ética em Pesquisa}
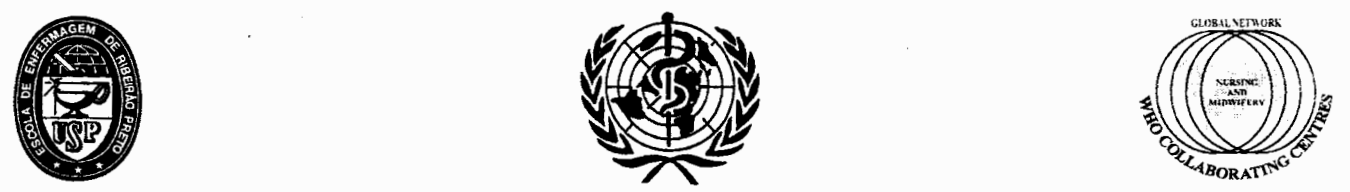

ESCOLA DE ENFERMAGEM DE RIBEIRÃO PRETO - UNIVERSIDADE DE SÃO PAULO CENTRO COLABORADOR DA ORGANIZAÇÃO MUNDIAL DA SAÚDE PARA O DESENVOLVIMENTO DA PESQUISA EM ENFERMAGEM

Avenida Bandeirantes, 3900 - Campus Universitário - Ribeirão Preto - CEP 14040-902 - São Paulo - Brasil FAX: (55)-16-3633-3271/3602-4419 / TELEFONE: (55) - 16-3602-3382

COMITÊ DE ÉTICA EM PESQUISA DA EERP/USP

Of.CEP-EERP/USP - 047/2008

Ribeirão Preto, 11 de março de 2008

Prezada Senhora,

Comunicamos que o projeto de pesquisa, abaixo especificado, foi analisado e considerado APROVADO AD REFERENDUM pelo Comitê de Ética em Pesquisa da Escola de Enfermagem de Ribeirão Preto da Universidade de São Paulo, em 11 de março de 2008.

Protocolo: $\quad n^{\circ} 0869 / 2008$

Projeto: DIREITOS DO PACIENTE DIABÉTICO AO TRATAMENTO: DA LEGISLAÇÃO À PRÁTICA.

Pesquisadores: Carla Regina de Souza Teixeira

Ellen Cristina Barbosa dos Santos

Em atendimento à Resolução 196/96, deverá ser encaminhado ao CEP o relatório final da pesquisa e a publicação de seus resultados, para acompanhamento, bem como comunicada qualquer intercorrência ou a sua interrupção.

Atenciosamente,

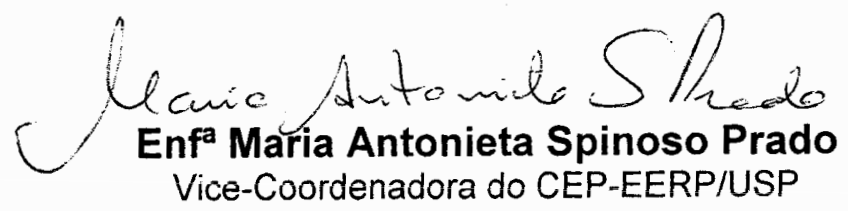

IIma. Sra.

Prof ${ }^{\mathrm{Dr}}{ }^{\mathrm{a}}$ Carla Regina de Souza Teixeira

Departamento de Enfermagem Geral e Especializada

Escola de Enfermagem de Ribeirão Preto - USP 